Historic, Archive Document

Do not assume content reflects current scientific knowledge, policies, or practices. 



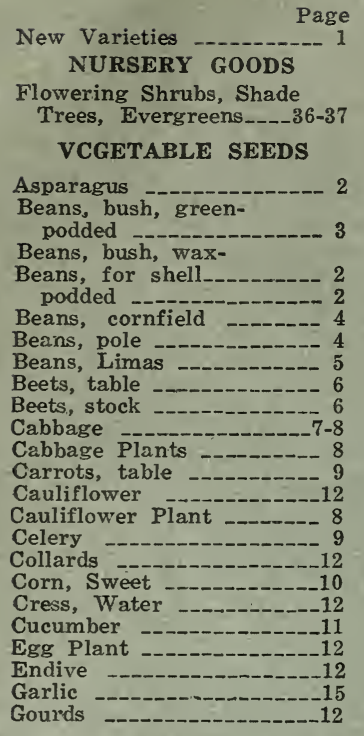

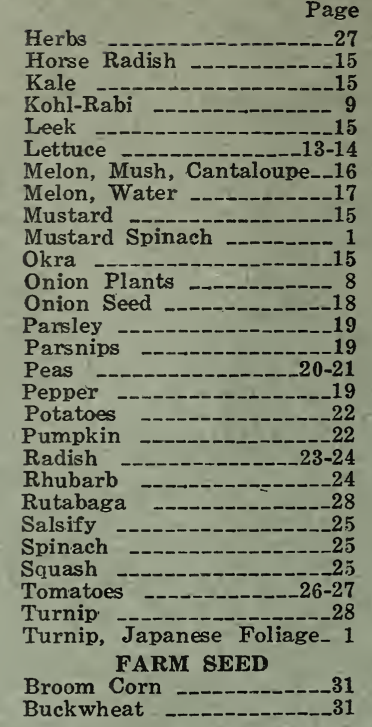

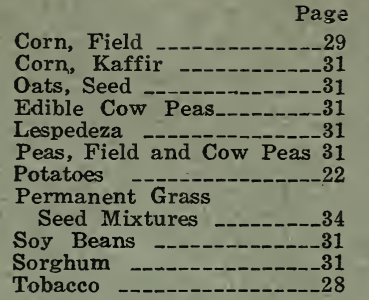

\section{FLOWER SEED AND} FLOWER BULBS

Flower Seed -----39-40-41-42 Clower Vines Caladiums - - Cannas Dahlia Bulbs Fall Planting Bulbs ----38 Gladiolas Peonies and Iris Maderia Vine -..-..-.43 Sweet Peas -_[uberoses -

\section{MISCELLANEOUS}

Apple Trees -_.

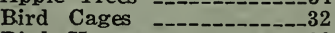

Bird Houses -
Page

Bird Food and Remedies_-33

Bordeaux Mixture -.-...44

Burpee Can Sealer.--..-32

Can Sealer

Feeny Duster ------

Fertilizer

Fruit Trees --_---_-_-_3

Grape Vines --_-_----34

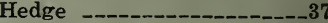

Hotkans -

Insecticides -------- 44

Lawn Grass - -

Lime Sulphur --_----44

Nitragin --.----

Orchard Supplies

and Pruners

Piultry Supplies, Inside

Back Cover.

Roses

Sealecide

Seed Sowers ---

Sparrow Traps -

Spray Pumps, Auto----45

Spray Pumps, bbl.

Steam Pressure Cooker --32

Strawberry Plants -_-_-_35

Sulphur

Tobacco Dust -

Vigoro -

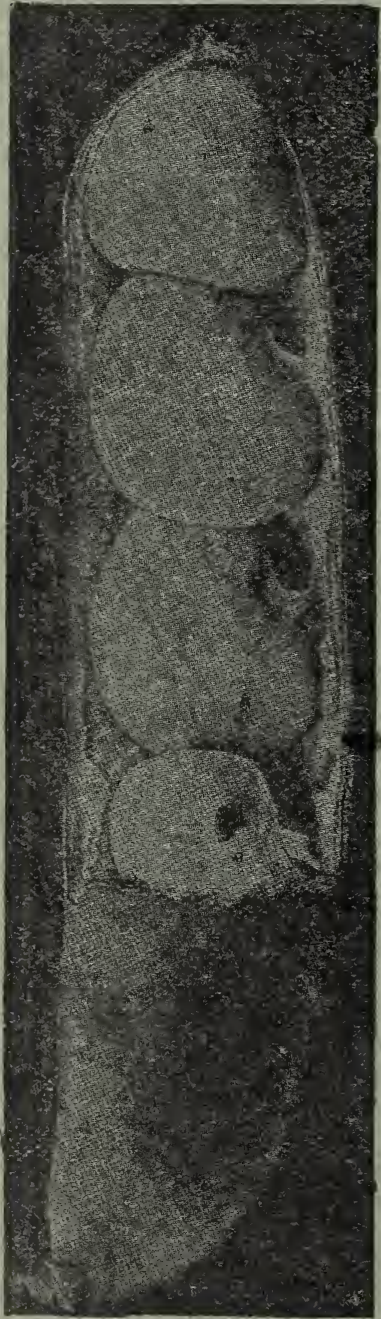

\section{YOPPS White Bush Lima}

This wonderful new type Southern Butter Bean has proven a splendid success the five years we have been producing it. Beautiful snow white when dry. Unusually heavy producer and very rich in flavor. Size nearly twice as large as the Henderson Bush Lima. Has become the most popular Bush Lima with the Market Gardener as well as Home Gardeners. This is the first season we have been able to of fer this new Butter Bean in quantity lots and we heartily recommend it for all sections of the South. Price 1 lb. $40 \mathrm{c}, 5$ lbs. $\$ 1.75,10$ lbs. \$3.50. 100 lbs. $\$ 30.00$.

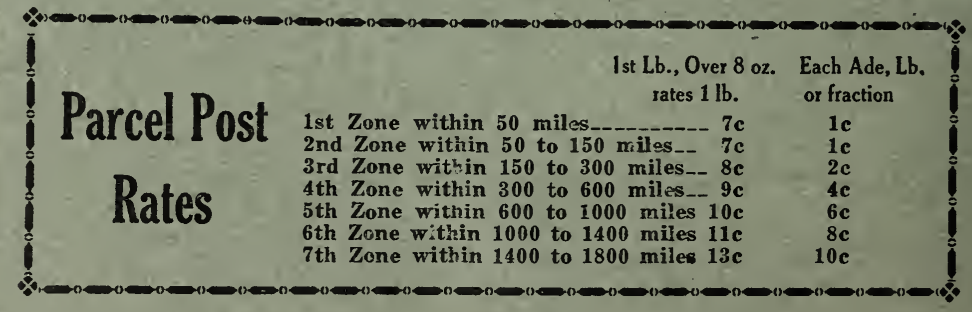

IRIS, by F. F. Rockwell. A handy guide which will bring you success with iris and show new uses and effects possible in your garden. Describe the dwarf, early, German, Japanese, Siberian, water, crested, Spanish, English, Dutch and other types: tells the best soils; what fertilizers to use; how to plant; and what care is necessary. Tells how to propagate stock for your own use. 54 illustrations, 80 pages, $\$ 1.00$.

AROUND THE YEAR IN THE GARDEN, by F. F. Rockwell Because the time when you do your garden work is so important, you need a regular schedule. This book gives you complete information on every garden problem, outlined week by week, and written by a practical gardener. 88 illustrations, 350 pages, $\$ 2.5$

HOME FLOWER GROWING, by E. C, Volz, A real flower garden encyclopedia! It will teach you how to propagate and cultivate your plants, how to care for, fertilize, and maintain them. It tells how and when and where to grow flowers; what different kinds look like; how to plan indoor, outdoor, rock, and water gardens; how to prepare exhibits for a flower show; how to organize a garden club. 151 illustrationz, 364 pages. 3.50.

LAWNS, by F. F. Rockwell. You will find use for this information year after year, for it shows both how to start a lawn righ and how to keep it smooth and velvety thereafter. Full of suggestions on laying out the lawn, grading, fertilizing, planting care after planting, weed and pest control, and remaking and repairing old lawns. 39 illustrations, 87 pages. $\$ 1.00$.

SHRUBS, by F. F. Rockwell. Here is brief but complete and usable information on the best ways to improve the beauty and value of your home with shrubs. Tells what to select for different combinations and effects, and how to plant, water, mulch, prune, and care for shrubs. 49 illustrations, 76 pages. $\$ 1.00$. 
Prices of All Garden Seed Include Postage on Pkts., Ozs., 1/4 lb. and $1 \mathrm{lb}$., Except PEAS, BEANS, SEED CORN and FIELD SEED. For Postage on these, see Inside Cover Page.

\section{Order Sheet to}

"Always Best Seed Grown"

VERY IMPORTANT

PADUCAH, KY.

Write your name very plainly, and give your Post Office, County and State in full every time.

Your Name

$$
\text { Very plain }
$$

\section{Post Office}

County

State

R. F. D.

Express or $\left\{\begin{array}{l}\text { If Different } \\ \text { From P. O. }\end{array}\right\}$

\section{How to Send Money}

Send Money by Express Money Order, Postal Money Order or Check.

\section{Do Not Write in This Space}

Date Rec'd

Filled by

Date shipped

Date. 1931

Gentlemen: Enclosed find \$-.--_-_-----_for which please send me the following:

NOTICE: We give no warranty, express or implied, as to description, quality, productiveness, or any other matter of any seeds, bulbs or plants we sell, and we will not be responsible for the crop. YOPP SEED CO.

\begin{tabular}{l|c|c|c|c|c|}
\hline \hline Quantity & Size & & & & \\
\hline \\
\hline
\end{tabular}




\section{We Sell Poultry Supplies, Insecticides, Spray Pumps and Garden Tools}

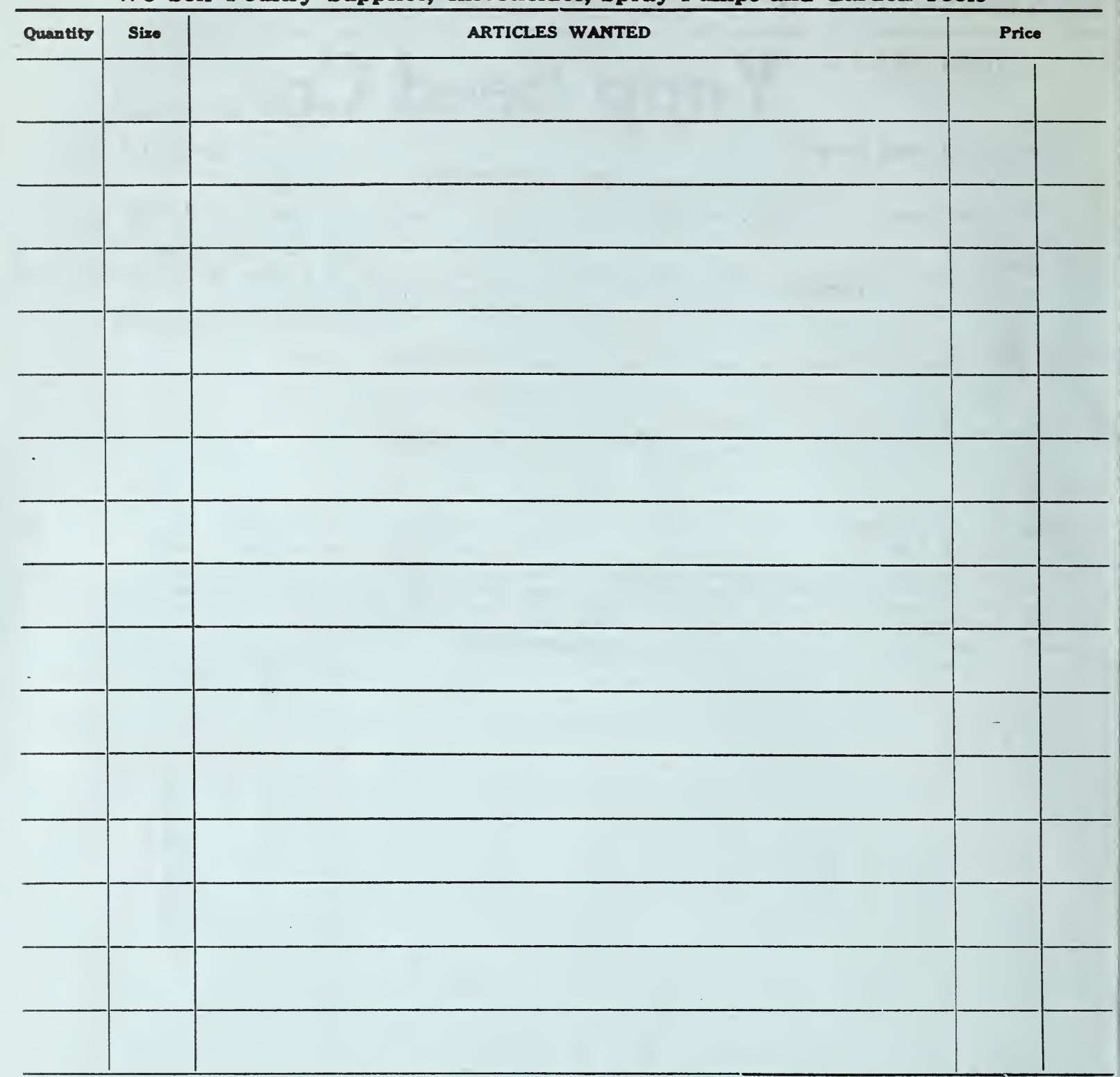

Kindly give below the names of any friends or neighbors whom you think would be interested in receiving our catalog:

\begin{tabular}{c|c|c|c}
\hline NAME & POST OFFICE & STATE \\
\hline & & & \\
\hline & & & \\
\hline & & & \\
\hline
\end{tabular}




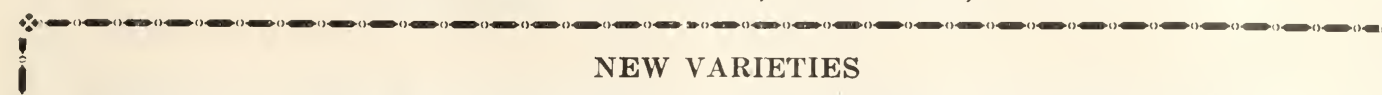

These two new varieties of vegetables listed on this page are not novelties, but are outstanding varieties that have been tried and have proven their unusual worth. We recommend them to the most critical market gardeners, also think that each home garden should contain at least some of these new varieties of regetables.

Japanese Louse Resistant Turnip. We could not recommend too highly this new a combination for both Greens and Turnips; the bulbous root is the sweetest ily. It is louse resistant and the tops or Greens are very large up

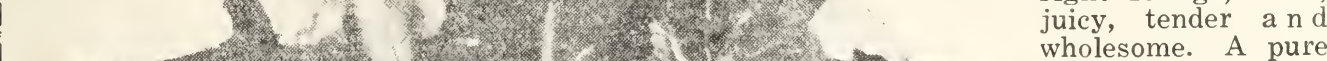

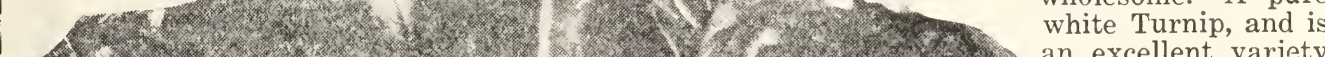

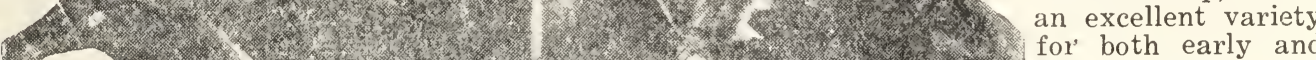

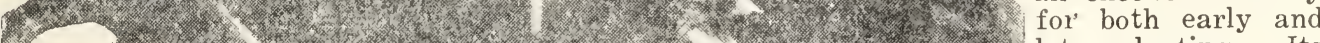

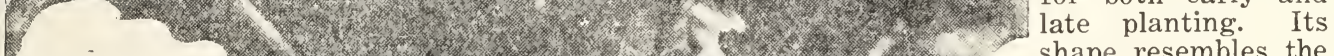

\section{NEW}

JAPANESE

MUSTARD

SPINACH

A wonderful new Vege-

\section{table Green. Japanese}

Mustard Spinach is the new vegetable introduced into America just recent-

- ly as a most wonderful tender

I Green, wholesome and de-

licious food for human consumption, has a delicious fla-

vor of Spinach, Mustard, and

Turnip Green combined. As an Eating-Quality, in mineral and many other rich developing material of building body and bone of the human system, this Japanese Mustard Spinach is unequalled. shape resembles the Purple Top Globe except flatter on top. Sweet, mild and excellent in flavor. We sold this wonderful Louse Resistant Turnip Seed to all parts of Kentucky and other states of the South last year and all reports show excellent and very satisfactory results. It is very popular and will be planted in large acreage in all turnip growing sections of the South this year for both early Greens as well as spring and regular crop Turnips. Ounce

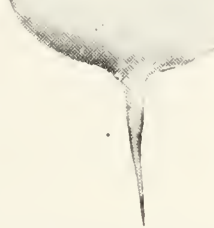
10 c, $1 / 4$ lb. 25 c, 1 lb. 75 c, 5 lbs. $\$ 3.00$

Japanese Mustard Spinach, a vegetable for long years, the standby of the Japanese, the vegetable-diet-people from generation to generation, has been the most important food of their daily life,

Japanese Mustard Spinach practically is far superior to Spinach, Turnip Green, Mustard, or Kale in flavor. We respectively recommend you this, the best Vegetable Green for the table use, as well as its preserving merit for the canning factories.

Culture of this Japanese Mustard Spinach is very simple and similar to that for Spinach, Lettuce, o: Mustard in general, is one of the quickest growing vegetables, that is for table use or market, in 3 or 4 weeks after planting. And this will produce 5 or more crops a year, can be planted almost every month in the year. in localities of the Southern States. However, the best results can be obtained during the season of Spring and again with Fall plantings.

Japanese Mustard Spinach will stand extreme weather better than any other vegetable, will grow in hot Summer months, and late Fall.

Sow the seed in open grounds, in rows a quarter inch deep and 24 inches apart each way, allowing about $2 \frac{1 / 2}{2}$ to 3 inches between the seeds. Cultivate and irrigate well One ounce of seed to 50 feet of drill, and 5 to 6 pounds to an acre in drills.

Japanese Mustard Spinach does not make roois like Turnips, but they are small and thin, about 2 to 3 inches long. It grows a beautiful green appearance, the leaves are large and oblong shaped, rather deep in color with a small center rib.

Japanese Mustard Spinach is very tender Green. The leaves are cooked and prepared for the table dse like Spinach or Turnip Greens, seasoned with salt, pepper and butter as desired. Ounce 10c, $1 / 4$ $1 b .25 \mathrm{c}, \mathrm{lb}, 75 \mathrm{c}, 5 \mathrm{lbs}, \$ 3.00$, Postage prepaid.

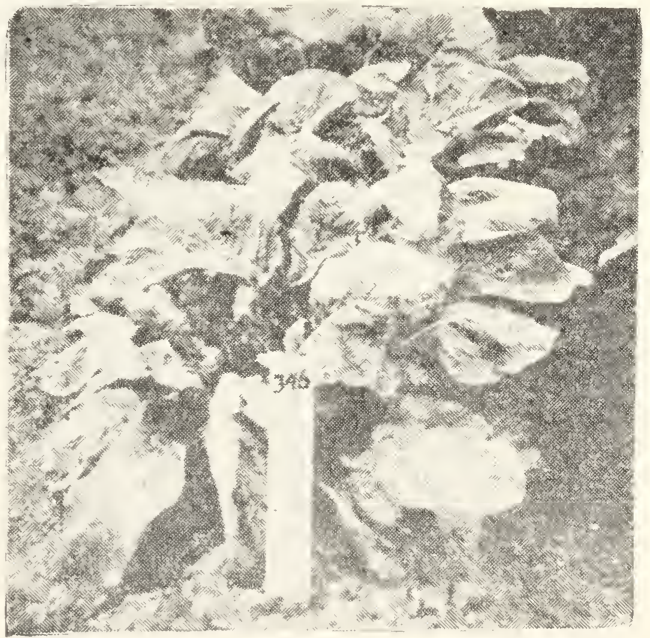

NEW JAPANESE MUSTARD SPINACH

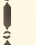

\section{,}




\section{GENERAL LIST OF VEGETABLE SEEDS IN BULK AND PACKETS}

With Cultural Instructions and General Information for All Varieties

NOTICE: We give no warranty, express or implied as to description, quality, productiveness, or any other matter of any seeds, bulbs or plants we sell, and we will not be responsible for the crop. YOPP SEED CO.

\section{ASPARAGUS SEED}

Prices Include Postage

Mary Washington. The finest and largest variety of Asparagus now known. Extremely resistant to rust. Very vigorous grower, and is very tender, and is most uniform. Our seed are pure pedigreed strain. Pkt. 10c, oz, 15c, $1 / 4$ lb. 50c, 1 lb. $\$ 1.50$.

\section{2-YEAR-OLD ASPARAGUS ROOTS}

Price for roots, well packed, to go by freight or express at buyer's expense:

$50 \quad 100$

Mary Washington _._.______. 90c $\$ 1.50$

If wanted by mail, add $10 \mathrm{c}$ for postage on 50 roots and $15 \mathrm{c}$ for postage on 100 roots.

Write for Prices on Large Lots

\section{WAX PODDED DWARF BEANS}

Prolific Black Wax. (60 days). This is a much improved strain of the old black wax. Its habit of growth is stronger; it has longer, straighter, and more rounded pods, and is far more productive. Pkt. $15 \mathrm{c}, 1 \mathrm{lb}$. 30c. 5 lbs. $\$ 1.25,10 \mathrm{lbs}$. $\$ 2.25$.

Wardwell's Kidney Wax.

$(58$ days). The very strong growing vines of this variety yield a large crop of long, nearly straight, broad, creamy white, handsome pods.Pkt. $15 \mathrm{c}, 1 \mathrm{lb} .30 \mathrm{c}, 5 \mathrm{lbs}$. $\$ 1.25,10 \mathrm{lbs}$. $\$ 2.25$.

Improved Golden Wax. (52 days). The plants are hardy and bear an abundance of straight, broad, flat pods. Resist rust to a marked degree. Pkt. 15c, 1 lb. 30c, 5 lbs. $\$ 1.25,10$ lbs. $\$ 2.25$.

WRITE FOR PRICES ON LARGER QUANTITIES

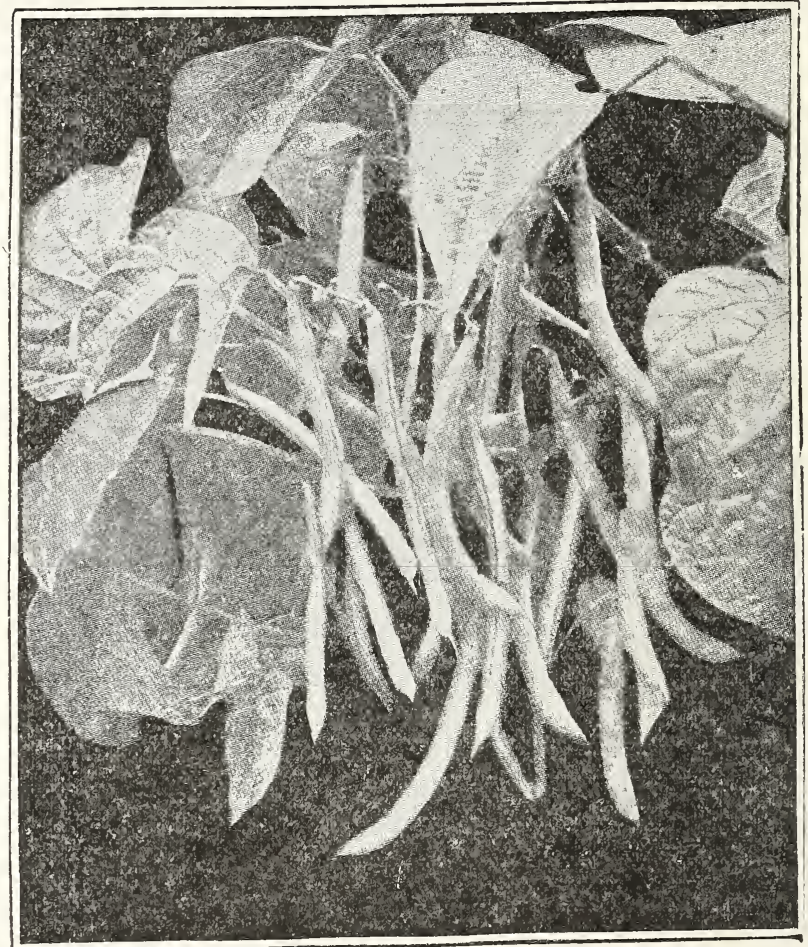

PROLIFIC BLACK WAX

\section{VARIETIES FOR SHELLED BEANS ONLY}

Known in Some Sections as Tobacco Patch Beans

Dwarf Horticultural. Large green pods, splashed with carmine. Excellent either as snaps in the green state, or shelled green or dry. Pkt. 15c, 1 lb. 30c, 5 lbs. $\$ 1.25,10$ lbs. $\$ 2.25$.

Royal Dwarf White Kidney. Excellent green or dry for soup, boiling or as baked beans. Pkt. 15c, 1 lb. 25c, 5 lbs. \$1.10, 10 lbs. \$2.00.

French Red Kidney. Similar to above; beans are maroon color. Pkt. 15c, 1 lb. 30c, 5 lbs. $\$ 1.40,10$ lbs. $\$ 2.50$.
Large White Marrow. Vine large, slender, with short runners; very prolific. Seed large, clear white, cooking very dry and mealy. Pkt. 15c, 1 lb. 25c, 5 lbs. $\$ 1.10,10$ lbs. $\$ 2.00$.

Dwarf White Navy. Is a sure cropper. Vine large, spreading, with small, thin leaves and occasional runners, ripening its crop early, and all at once. The beans are small, oval, white, handsome and of superior quality. Pkt. 15c, 1 lb. 25c, 5 lbs. $\$ 1.00,10$ lbs. $\$ 1.80$. 
CULTURE-All garden beans are tender and should not be planted until danger from late frosts have passed. CULTURE-All garden beans are tender and should not be planted until danger from late frosts have passed.
Any ordinary good warm garden loam will grow the dwarf kinds well. The best method of culture is to plant in rows two feet apart, sowing the beans two inches apart and two inches deep in the row. Working them wet with rain or dew makes them more liable to rust and injure the crop. For succession, sow at intervals of about two weeks until late August. For Extra Early Crops, drill sheep manure over the row to a depth of one to two inches. This prevents the ground from crusting and also adds much strength and vitality to the plants.

\section{POSTAGE EXTRA ON BEANS \\ FOR POSTAGE RATES, SEE INSIDE FRONT COVER PAGE}

One pound sows 80 feet drill. An acre requires one to one and a half bushels.

Stringless Black Valentine. A new Bean, has the hardiness and earliness of the Old Black Valentine, pods are long, round, smooth, bright green color, entirely stringless and tender. Pkt. 25c, 1 lb. 50c, 5 lbs. $\$ 2.00,10$ lbs. $\$ 4.00$.

Tennessee Green Pod. (60 days.) A favorite sort in Tennessee and in the Middle Southern States. The beans are brown in color, a little larger than Kentucky Wonders, and are very hardy. It is very productive, producing long, flat pods, and on account of its extreme earliness and productiveness it is very popular. Pkt. 15c, 1 lb. 30c, 5 lbs. $\$ 1.25,10$ lbs. $\$ 2.25$

Giant Stringless Green Pod. (62 days.) This is an exceptional variety, possessing all the merits of its namesake, the stringless green pod, with much lasger pods. Pkt. 15c, 1 lb. 30c, 5 lbs. \$1.25, 10 !bs $\$ 2.25$.

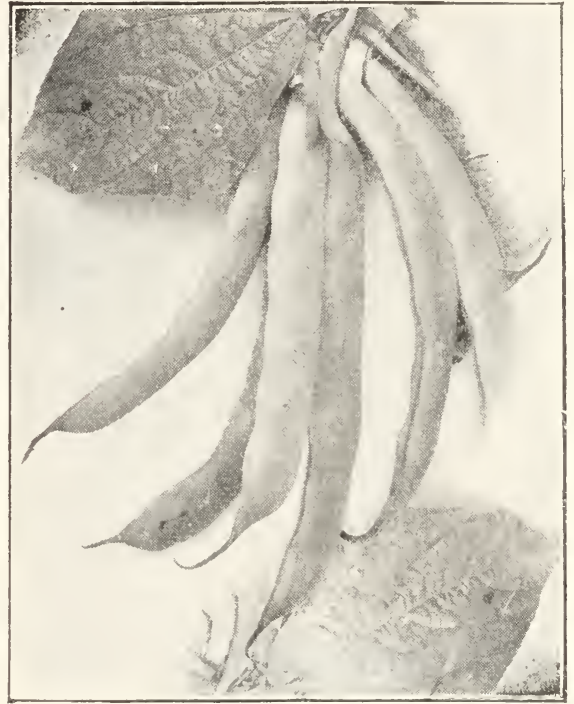

BOUNTIFUL

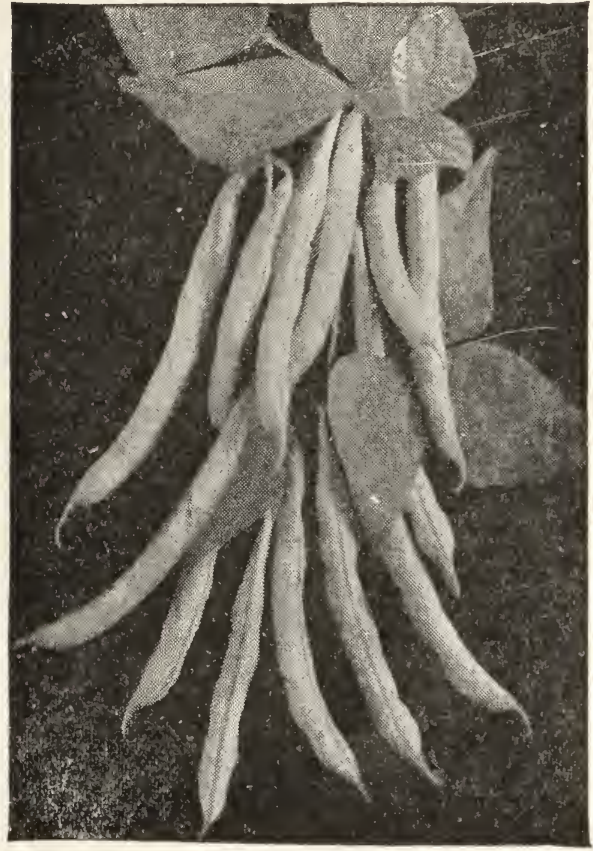

EXTRA EARLY RED VALENTINE

Bountiful. (52 days.) Of thrifty growth rust and mildew proof; is very hardy; extremely early, bountifully prolific and bears continuously for several weeks. This variety bears immense green pods; thick, broad and extra long, of the highest quality. Is absolutely stringless. Pkt. 15c, 1 lb. 35c, 5 lbss. $\$ 1.25,10$ lbs. $\$ 2.25$.

Full Measure. (64 days.) This magnificent round podded bush bean bears long, green pods, always solid and exceedingly prolific. The pods are of an attractive green color, 5 inches long, firm, tender and remain fit for use many days after maturity. Pkt. 15c, 1 lb. 35c, 5lbs. $\$ 1.50,10$ lbs. $\$ 2.70$.

Extra Early Red Valentine. (56 days.) This variety was for many years the standard green pod Snap Bean, and the improved strain we now offer is surpassed in earliness and quality only by the stringless green pod. The pods are fleshy, round and sadclebacked, and while not stringless, are very profuse. Pkt. 15c, 1 lb. 30 c, 5 lbs. $\$ 1.25,10$ lbs. $\$ 2.25$.

Burpee's Stringless Green Pod. (58 days.) Without any exception it surpasses all others in crisp, tender flavor. Handsome, straight, green pods; all absolutely stringless and of beautiful fleshy appearance. Pkt. 15c, 1 lb. 30 c, 5 lbs. $\$ 1.25$, 10 lbs. $\$ 2.25$.

WRITE FOR PRICES ON LARGER QUANTITIES

REMEMBER-Yopp's "Chief Brand" Field Seed is Always Best Seed Grown

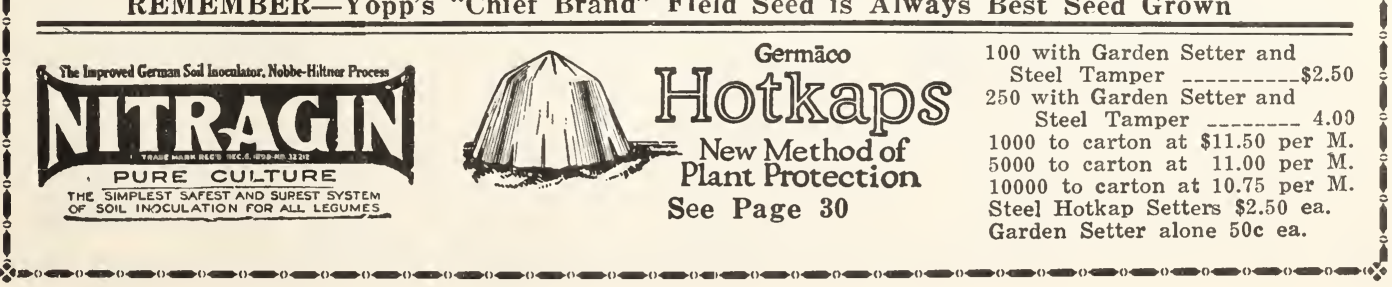




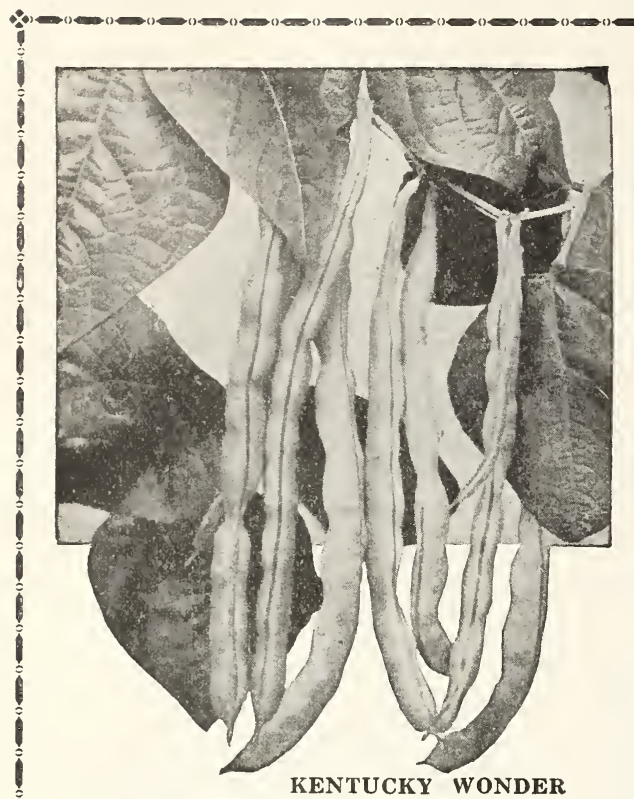

POLE OR CORNFIELD BEANS

CULTURE-Pole beans are tender and should be planted a couple of weeks later than the bush variety. A sandy loam soil, liberally manured, assures the best success. Plant in rows three feet apart, 6 beans to a hill, each hill two feet apart. After runners have started, thin to four plants to hill, setting your poles which should be five to eight feet long. Use one pound for 150 hills. $1 / 2$ bushel to the acre.

Pole Beans are more easily gathered than the Dwarf Beans and yield more. They need good, strong poles, and are often planted with corn.

\section{POSTAGE EXTRA}

For Postage, see inside front cover page.

Yopp's Bushel Corn Field Bean. (72 days.) One of the best Corn Field Beans. Green podded, produces beans in clusters. Very productive. On account of the great number of beans on each vine, hence the name Bushel Bean; bears over a long period of season. Pkt. 15c, $1 \mathrm{lb} .25 \mathrm{c}, 5 \mathrm{lbs} . \$ 1.10,10$ lbs. $\$ 2.00$.

Striped Creaseback. (72 days.) One of the best cornfield beans grown. Is very vigorous and wonderfully productive in good soil. Pods round and quite fleshy, borne in clusters from four to twelve. Good length, silvery green color, and are the best quality as snaps. Pkt. 15c, 1 lb. 25c, 5 lbs. $\$ 1.10,10$ lbs. $\$ 2.00$.

Kentucky Wonder. (68 days.) Also known as Old Homestead. We believe this variety is the most practically useful of the green podded pole beans suitable for use as snaps. It is an early, very prolific sort, with showy pods which are of most excellent quality. The vines are vigorous, climbing well and very productive, bearing pods in large clusters. The pods are medium light green, very long, often reaching nine or ten inches, curved and twisted, nearly round and very crisp when young, becoming very irregular and spongy as the beans ripen. Seeds long, oval, slightly flattened, dun colored. Pkt. 15c, 1 lb. 25c, 5 lbs. \$1.10, 10 lbs. $\$ 2.00$.

Dutch Case Knife. (68 days.) Pods very long, flat irregular, green, but becoming creamy white as they mature. Seed broad, kidney-shaped flat, clear white and of excellent quality, green or dry. Pkt. 15c, 1 lb. 25c, 5 lbs. $\$ 1.10,10$ lbs. $\$ 2.00$.

White Seeded Kentucky Wonder. (68 days.) (Or Burger's Stringless Green Pod.) Early, yet bears for a long season. The pods, six to eight inches long, are borne in clusters, are of rich, dark green color, very meaty, entirely stringless, tender and of excellent flavor and quality. The pearly white beans make splendid dry beans for winter use. Pkt. 15c, 1 lb. 25c, 5 lbs. $\$ 1.10,10$ lbs. $\$ 2.00$.
Red Speckled Cut-Short. (76 days.) An old variety, very popular in the Central and Southern States for planting among corn. Pkt. 15c, 1 lb. 25c, 5 lbs. \$1.10, 10 lbs. \$2.00.

White Creaseback. ( 75 days.) The pods grow in clusters, are perfectly round and deeply creased or saddlebacked. Pkt. 15c, 1 lb. 25c, 5 lbs. $\$ 1.10,10$ lbs. $\$ 2.00$.

McCaslan. (68 days.) of a rich dark green color; 10 inches long, rather flat and slightly curved. It is productive and of good quality. White-seeded. Pkt. 15c, 1 lb. 30c, 5 lbs. $\$ 1.25,10$ lbs. $\$ 2.25$.

London Horticultural. One of the best varieties as a general purpose late green shell bean for home or market. The heans are large, oval, flesh-colored, splashed and spotted.with wine red and of the highest auality either green or dry. Pkt. 15c, $1 \mathrm{lb}$. 25c, 5 lbs. $\$ 1.10,10$ lbs. $\$ 2.00$.

Lazy Wife. (84 days.) One of the best of the later green podded pole beans for snaps or green shell use. The medium green pods, borne in large clusters, are five and one-half to six and one-half inches long, broad, thick, fleshy and entirely stringless. The seed is white, medium size, slightly oval or nearly round. Pkt. 15c, $1 \mathrm{lb} .25 \mathrm{c}, 5 \mathrm{lbs}$. $\$ 1.10,10$ lbs. $\$ 2.25$.

Kentucky Wonder Wax. (68 days.) This vigorous growing wax podded pole bean is very similar to the green podded Kentucky Wonder. Pkt. 15c, 1 lb. 25c, 5 lbs. \$1.10, 10 lbs. $\$ 2.00$.

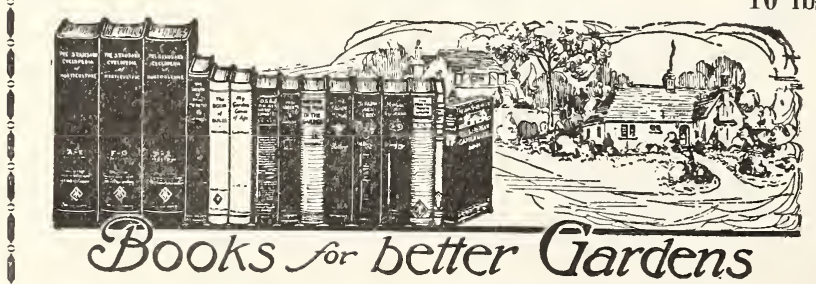

See inside front cover for list and prices

Mixed Cornfield Beans. A mixture of cornfield beans, cut-shorts, long pods, early and late beans, to insure green beans throughout the entire soason. Fine for planting in corn. Pkt. 15c, 1 lb. 25c, 5 lbs, \$1.10, 10 lbs. $\$ 2.00$.

Write for Prices on Larger Quantities

WHEN YOU PLANT, YOU WANT THE BEST. SOW YOPP'S CHIEF BRAND FIELD SEED. THEY ARE THE BEST SEED GROWN 


\section{LIMA BEANS-DWARF OR BUSH VARIETIES}

CULTURE-Plant in May in rows like Dwarf Snap Beans; drop two beans every 12 or 15 inches apart. Cultivate like Snap Beans.

Dwarf Lima Beans are preferable for small gardens, especially in places where poles are hard to obtain. One pound of small-seeded sorts plants from 100 to 125 feet, and is sufficient for ordinary gardens or 2 pounds of large seeded sorts. For succession make two plantings 4 weeks apart.

For Postage, See Inside Front Cover Page.

Henderson's Dwarf Lima. (74 days.) The original Bush Lima Bean. Of the true Bush type, the bush grows from 18 to 20 inches high. Early to mature. Productive and a sure cropper. Beans much smaller in size than Burpee's Bush, and of same tender, buttery flavor as the old Pole Butter or Sieva Beans of the South. Pkt. 15c, 1 lb. 30 c, 5 lbs. \$1.25, 10 lbs. \$2.20.

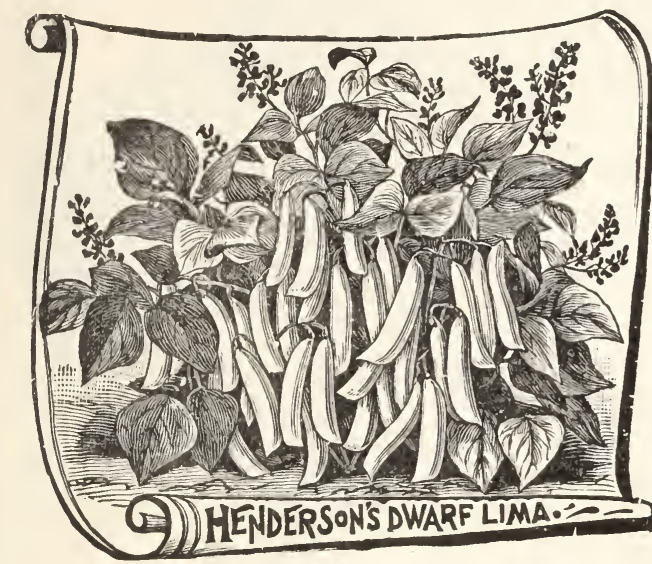

POLE LIMA BEANS

Burpee's Bush Lima. (75 days.) A bush form of the true Large Lima. Plants uniformly dwarf, but enormously productive. Pods are large and contain from three to five very large flat beans of best quality. Pkt. 15c, 1 lb. 35c, 5 lbs. $\$ 1.50,10$ lbs. $\$ 2.50$.

New Wonder Bush Lima. (78 days.) The plant more dwarf and less inclined to make runners than any other large Bush Lima. Beans broader and more flat. Very productive. Pkt. 15 c, 1 lb. 35c, 5 lbs. \$1.50, 10 lbs. \$2.50.

Yopp's White Bush Lima. (75 days). This Bean while similar to Yopp's Pole Lima is a true strain of Bush Lima (Southern Butter Bean), the pods containing large white beans almost twice as large as Henderson's Bush Lima. Very prolific. This is one of the best Southern Butter Beans introduced. Pkt. 15c, $1 \mathrm{lb} .40 \mathrm{c}$, 5 lbs. $\$ 1.75$, 10 lbs. $\$ 3.50$, 100 lbs. $\$ 30.00$

CULTURE-Plant about 4 to 5 beans to the hill after the ground is warm, about 4 feet apart, and set poles. Use the hoe for cultivating.

Henderson's Leviathan. (85 days.) Matures four or five days earlier than ordinary Large Limas, producing large beans and well-filled pods. Pkt. 15c, 1 lb. 30c, 5 lbs. $\$ 1.25,10$ lbs. $\$ 2.20$

Large White Pole Lima. (90 days.) Somewhat smaller than the Henderson Leviathan. Well known. Pkt. 15c, 1 lb. 30 c, 5 lbs. $\$ 1.25,10$ lbs. $\$ 2.20$.

Small White Pole Lima. (82 days.) (Or Southern Butter Bean). It is rather small size, but bears enormously. Much better in this section than the large limas. Great many grow them to put away for winter use. Pkt. 15c, 1 lb. 30c, 5 lbs. $\$ 1.25,10$ lbs. $\$ 2.20$.

Yopp's White Pole Lima. (84 days.) This variety leads all other small white limas for either home garden or market. The beans are about twice the size of the small pole Lima, very tender, buttery flavor. Begins setting of pods from the first blooms and is an immensely heavy bearer from early to late. Excellent for either green or dry winter use. Especially adapted for the south. Pkt. 15c, 1 lb. 30c, 5 lbs. \$1.25, 10 lbs. $\$ 2.20$.

King of the Garden Pole Lima. (85 days.) The pods are long and contain 4 or 5 large White Beans of excellent quality, medium early, very productive. Pkt. 15c, 1 lb. 30c, 5 lbs. $\$ 1.25$, 10 lbs. $\$ 2.20$.

Speckled or Calico Pole Lima-A very prolific bearer and of excellent quality for table use, only some object to it on account of the color. Pkt. 15c, 1 lb. 30c, 5 lbs. \$1.25, 10 lbs. \$2.20.

Bean Diseases. For rust and blight, spray beans with Bordeaux Mixture when in third leaf, and thereafter at intervals of 10 to 14 days.

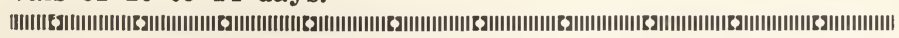

IF YOU WANT THE BEST SEED, SOW YOPP'S CHIEF BRAND FIELD SEED. THEY ARE THE BEST SEED GROWN.

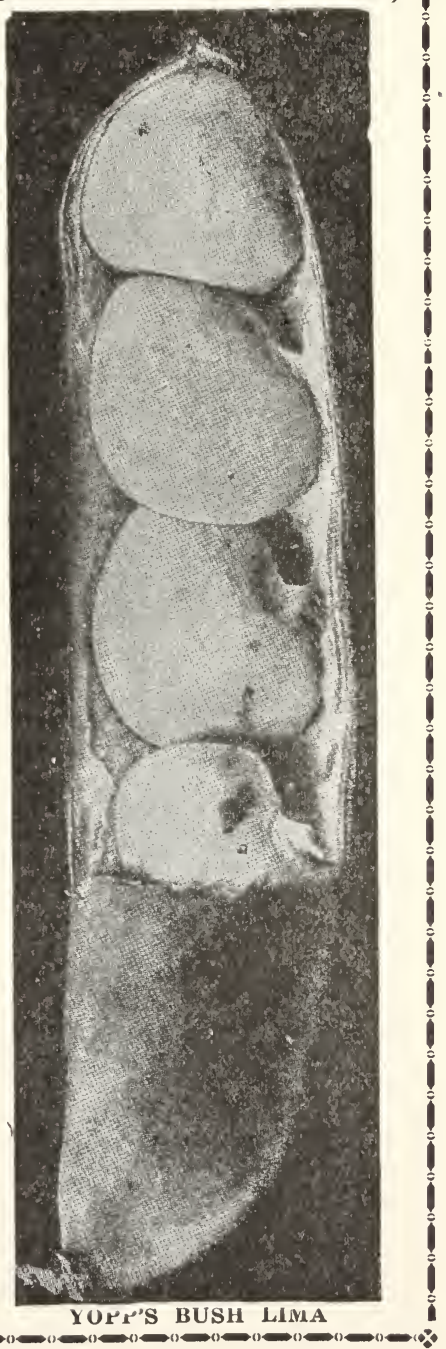




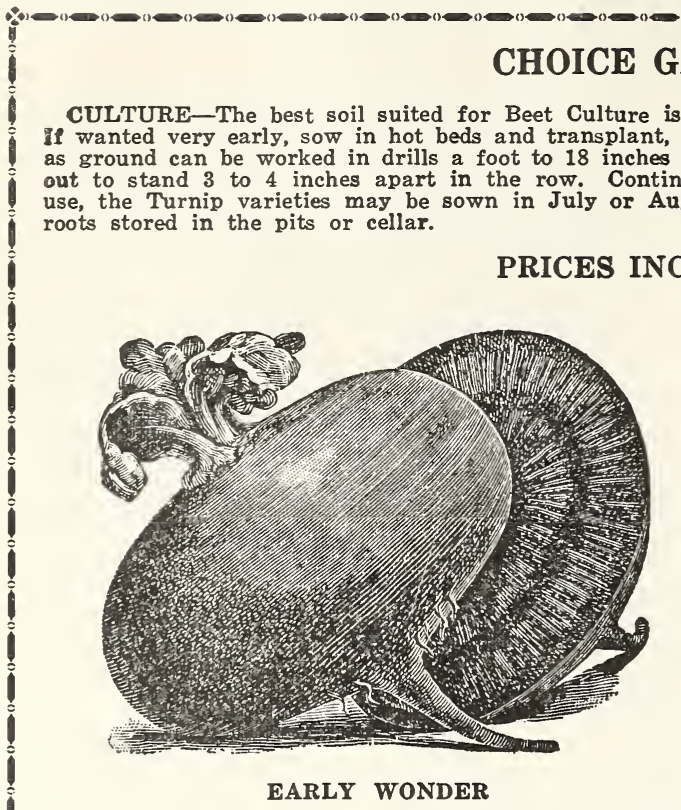

Early Wonder. (45 days.) Very early. The Beets are globe shape, very deep red, perfectly smooth with small tap root. The tops are unusually small. Very popular account of its attractive appearance, uniform size, shape and color. It is very crisp and tender, and much in demand by shippers.

Pkt. 10c, oz. 15c, $1 / 4$ lb. 35c, lb. $\$ 1.00$.

Detroit Dark Red. (50 days.) A splendid turnip beet with very small upright tops, maturing early. Makes nice, round, fine-shaped roots. Is one of the finest of all for early market or home use, and will be found one of the best of all for forcing in hot beds. Pkt. $10 \mathrm{c}$, oz. $15 \mathrm{c}, 1 / 4 \mathrm{lb}$. $35 \mathrm{c}, \mathrm{lb} .90 \mathrm{c}$.

\section{EVER GREEN}

See Page 44

Swiss Chard or Spinach Beet. In season from early spring to autumn frost, foliage used same as spinach; stems used for stewing. Pkt. 10c, 0z. 15c, 1/4 lb. 35c, $1 \mathrm{lb}$. $\$ 1.00$.

Crosby's Egyptian. (45 days.) An improved strain of the Egyptian Beet, which we especially recommend as an extra early and superior vort. It has been so improved in shape, size, a,opearance and quality, as compared with the

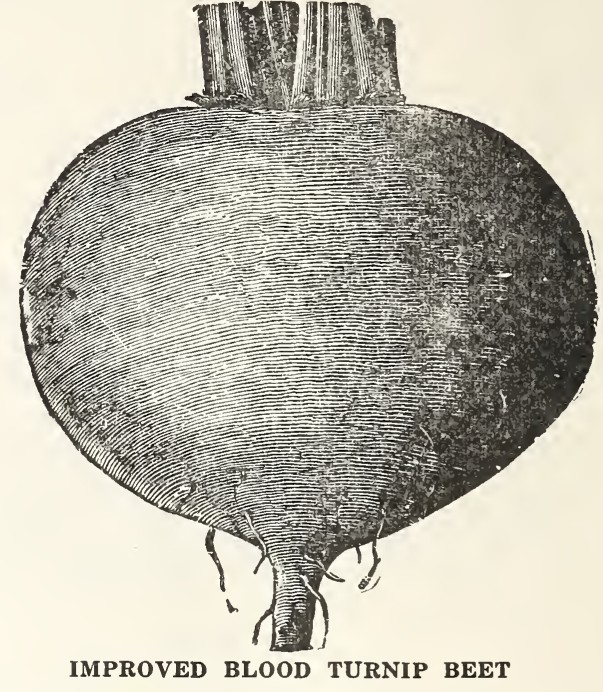

original, that it is now an entirely distinct variety. It has a large, globe-shaped root, is smooth, of a deep blood color, and is of the finest quality. Pkt. 10c, oz. 15c, $1 / 4$ lb. 35c, 1 lb. $\$ 1.00$.

Early Eclipse. (42 days.) One of the best table beets almost as early as the Egyptian and much superior in quality. Has small tops and is smooth, fine-grained and tender. Color bright red, sometimes with lighter zones. Pkt. 10c, oz. 15c, 1/4 lb. 35c, 1 lb. 90c.

Improved Blood Turnip Beet. (45 days.) The Blood Turnip Beet has always been considered the standard for general use. This special strain is the result of careful growing and selection, extending over a number of years until we are now satisfied that there is no chance for further improvement -in short, that it is perfect in every desirable quality. Pkt. 10c, oz. 15c. $1 / 4$ lb. 35c, 1 lb. 90c.

\section{CATTLE BEETS}

Mangel Beets Are Most Valuable for Stock Feeding. There is No Better Paying Root Crop. They Keep Well, and as a Change of Food, Are Excellent. Five Pounds Will Sow An Acre.

Long Red. (110 days.) A large, long variety grown for stock feeding. It stands up well above the surface; color, light red; flesh light and rose colored. Pkt. 10c, 1/4 lb. 20c, lb. 50c.

Golden Tankard. (90 days.) Shape cylindrical, color deep rich yellow, flesh yellow, circled with white, unequalled for feeding stock. Pkt. 10c, 1/4 lb. 20c, lb. 50c.

Sugar Klein Wanzleben. (60 days.) Largest yielding and one of the best for sugar making. Pkt. $10 \mathrm{c}, 1 / 4 \mathrm{lb} .20 \mathrm{c}, \mathrm{lb} .60 \mathrm{c}$. 


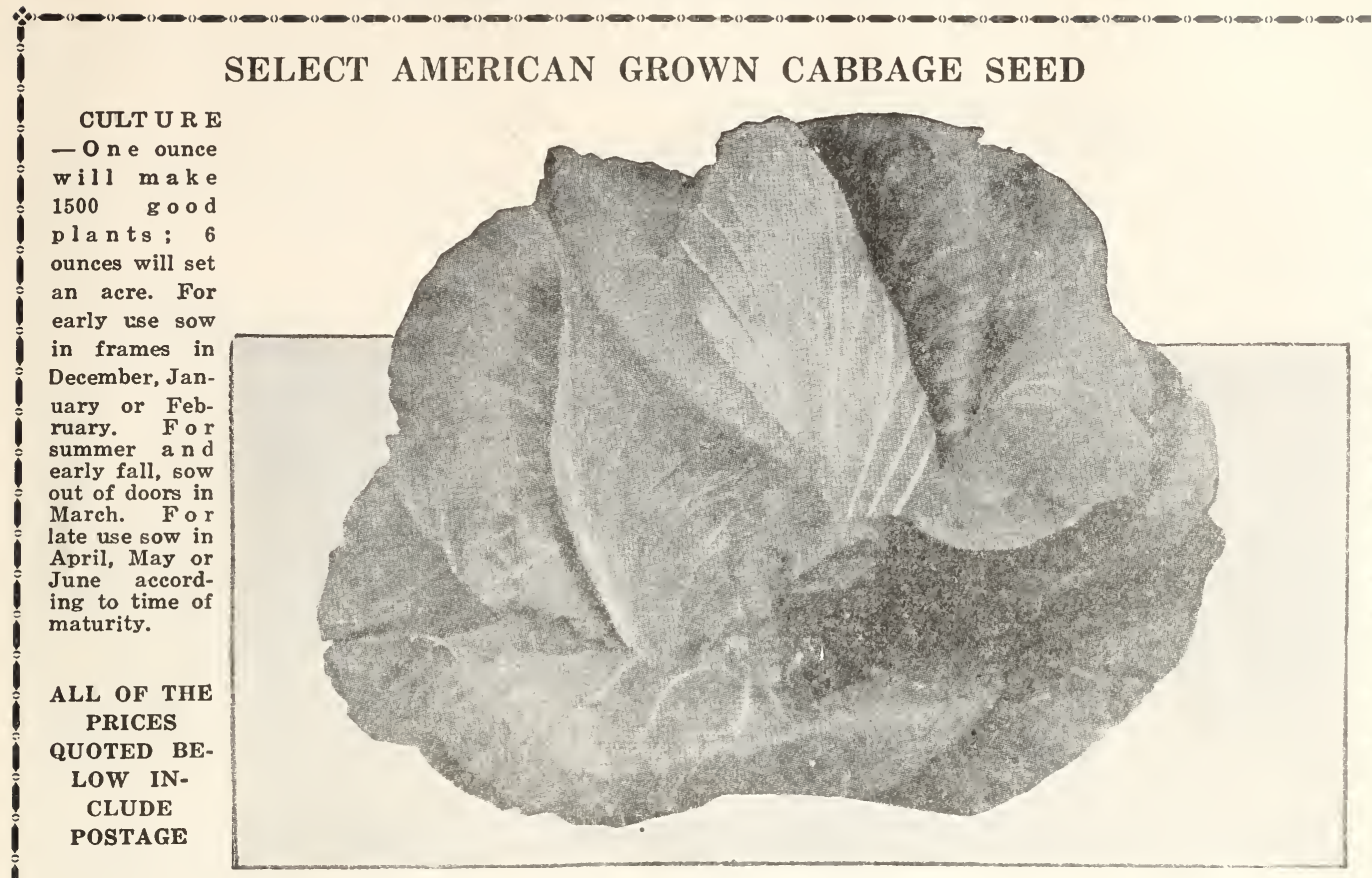

EARLY JERSEY WAKEFIELD

FIRST EARLY CABBAGE

Early Jersey Wakefield. (70 days.) The standard first early cabbage for the market grower. Heads conical and medium size. Our strain of this is specially fine. Pkt. 10c, oz. $25 c, 1 / 4$ lb. 75 c, lb. $\$ 2.50$.

Copenhagen Market. (80 days.) A valuable new early cabbage from Denmark, producing large, ball-shaped head, which comes into market along with Charleston Wakefield. It is well-known that Denmark is a great cabbage and cauliflower country. Our seeds come direct from the originator. Produces fine, large heads. uniform in shape and size and very solid. Pkt. 10 c, oz. 30 c, $1 / 4$ lb. $\$ 1.00$, lb. $\$ 3.00$.

Marion Market (Yellows Resistant). days.) A wonderful fine early variety of Yellows Resistent, round head Cabbage, heads being almost identical as Copenhagen Market; so if you cannot grow Cabbage on account of the Yellows or Wilt as it is sometimes called, be sure and try the Marion Market. Pkt. 10c, oz. 50 c, $1 / 4$ lb. $\$ 1.75$, lb. $\$ 6.00$.

Golden Acre. (70 days.) A new selection of the Copenhagen type; earliest of the round headed cabbages, maturing with Jersey Wakefield. Heads of medium size, round and hard, with few outer leaves. Pkt. 10c, oz. 50c, 1/4 lb. $\$ 1.75$, lb. $\$ 5.00$.

Large or Charleston Wakefield. (80 days.) The principle sort now planted by growers for early market, about a week later than Jersey Wakefield, but making much larger heads. Pkt. 10c, 0z. 25c, 1/4 lb. 75c, 1 lb. $\$ 2.50$.

\section{CABBAGE-Summer}

Early Flat Dutch. (100 days.) An old variety, but still popular. It succeeds anywhere, but seems especially suited to the South, because of its marked heat-resisting qualities. Pkt. 10c, oz. 25c, $1 / 4$ lb. 75 c. 1b. $\$ 2.50$.

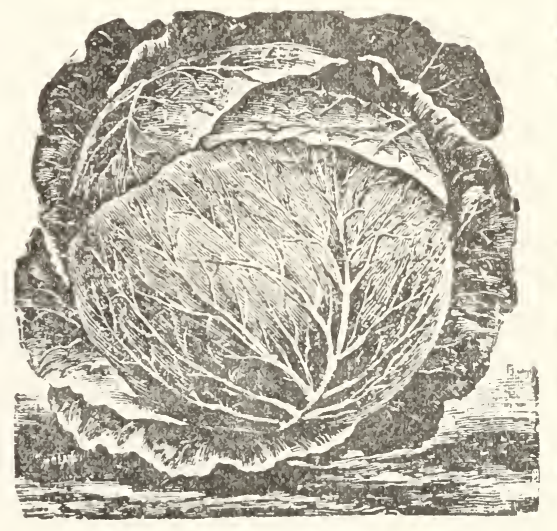

ALL HEAD EARLY

All Head Early. (100 days.) The largest heading of the second early sorts, of excellent quality. The deep, flat heads are remarkably solid and very uniform in size. Pkt. 10c, oz. 25c, 1/4 lb. 75c, lb. $\$ 2.50$.

Early Summer. (100 days.) This is a very valuable variety, not only for the market gardner, but also the private grower. Pkt. 10c, oz. 25c, $1 / 4$ lb. 75c, lb. $\$ 2.50$.

Succession. (100 days.) This variety, which originated on Long Island we regard as valuable an acquisition as the famous Early Summer. Pkt. 10c, oz. 25c, 1/4 lb. 75c, lb. $\$ 2.50$.

Wisconsin All Seasons. (Yellows Resistant.) This cabbage after extensive field tests has proven to be resistant against the disease known as "Yellows." In other respects same as regular All Season. A favorite for kraut making. Pkt. 10c, oz. 50c, $1 / 4$ lb. $\$ 1.75$, lb. $\$ 6.00$. 


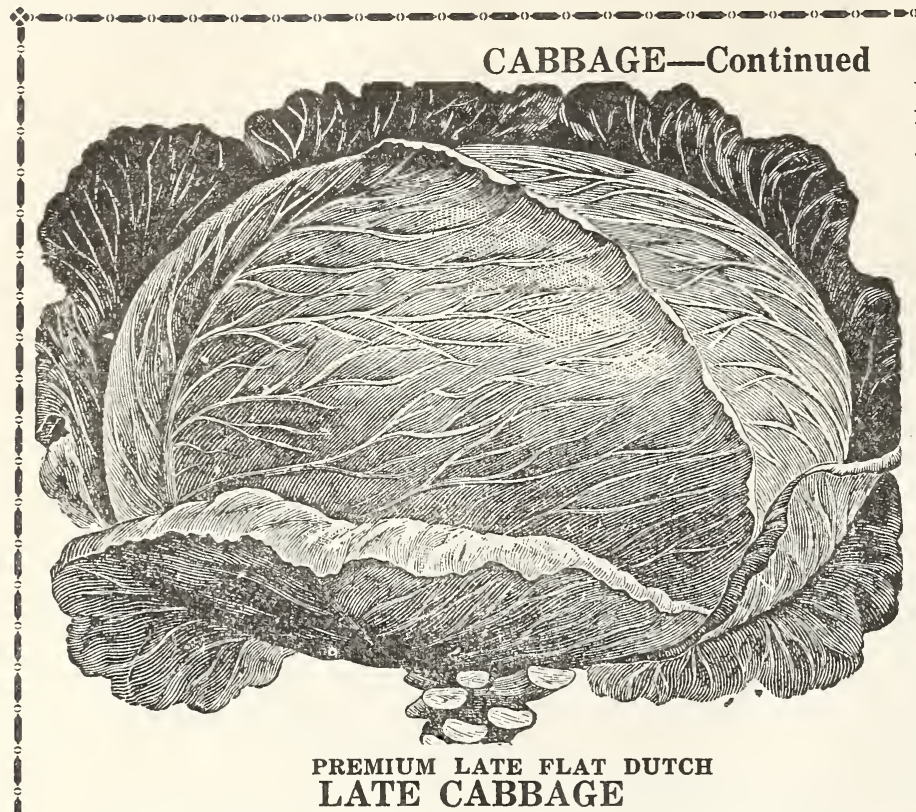

Premium Late Flat Dutch. (120 days.) This standard variety matures a little earlier than many of the late sorts, is of low growth, with large head, broad and flat. A sure crop producer. Pkt. 10c, oz. 25c, $1 / 4$ lb. 75 c, 1b. $\$ 2.50$.
All Seasons. (100 days.) No variety is more reliable than this in producing heads. Its rapid growth and good size make it desirable for either early or late planting. Pkt. 10c, oz. 25c, 1/4 lb. $75 \mathrm{c}, \mathrm{lb} . \$ 2.50$.

Late Drumhead. (120 days.) A sure heading sort, which in good rich soil, will grow to an enormous size, and on poorer soils will give good sized heads which are very compact, solid and of excellent flavor. Pkt. 10 c, oz. 25 c, $1 / 4$ lb. 75 c. lb. $\$ 2.50$.

Surehead. (115 days.) A cabbage of the general Flat Dutch type with the same large deep, somewhat flattened head and the same fine qualities, but is of better texture and has less spread of leaves. It is a late sort, uniform in growth, with firm. hard heads. Pkt. 10c, oz. 25 c, $1 / 4$ lb. 75 c, lb. $\$ 2.50$.

Mammoth Rock Red. This is the best, largest and surest heading red cabbage yet introduced. Pkt. 10c, oz. 30c.

\section{CHINESE CABBAGE}

Chinese Cabbage can be served as a salad like Lettuce, or when cut makes a delicious slaw; boiled it is even more palatable than ordinary cabbage. Sow seed in late July or August. Wong Bok. This variety has rather short broad heads, tightly folded leaves, blanches well, somewhat earlier than Pe-Tsai. Wili make a head when others fail. Pkt. 10c, oz. $25 \mathrm{c}, 1 / 4 \mathrm{lb} .80 \mathrm{c}, 1 \mathrm{~b} . \$ 3.00$.

Pe-Tsai. The best known variety. Has large leaves, light green color, pure white tender stalks. The ribs are juicy and agreeably pungent. Pkt. 10c, oz. 25c. 1/4 lb. 80c, lb. $\$ 3.00$.

\section{OUR FROST-PROOF PLANTS}

\section{Will Mature Two or Three Weeks Earlier Than Your Home Grown Plants and Double Your Profits}

The roots grow from the time they are planted, and just as soon as spring weather starts, the established root growth assimilates the fertilizer in the soil, the plants grow very fast, maturing two or three weeks earlier than you can mature them from hot bed and cold frame plants. You know what the difference in profit will be if your crop is matured and marketed before the general crop from home grown plants is matured
Cabbage Varieties: Early Jersey Wakefield, Charleston Large Type Wakefield, Succession and Early Flat Dutch. No Plants Shipped C. O. D. $10035 \mathrm{c}, 500 \$ 1.50,1,000 \$ 2.50$. Postage paid.

Orders are filled by the 100 , not 250 or 350 . Prices are for even quantities of one variety to package; if you ordered 200 of one variety and 300 of another variety you would pay at the 100 rate.

HOME GROWN CABBAGE PLANTS. Not Frost Proof-Early Varieties. $35 \mathrm{c}$ per 100 , postage included.

NOTICE-When ordering cabbage plants be sure to state whether you want Frost-Proof or Home Grown Plants; also if by parcel post or express.

FROST-PROOF CAULIFLOWER PLANTS. Postage charges prepaid. 100 to 400 at $90 \mathrm{c}$ per $100 ; 500$ for $\$ 3.75 ; 1,000$ or more at $\$ 6.00$ per 1000 .

\section{BERMUDA AND CRYSTAL WAX ONION PLANTS}

Onion Plants are taking the place of dry sets to a great extent now as the plants grow better shaped and seldom run to seed while Onions from sets run to seed a great deal. We recommend them particularly for home gardens. The Onion Plants are practically as hardy as Frost Proof Cabbage Plants, standing light freezes without being killed. Price: 100 for 25 c, 500 for 90 c, 1,000 for $\$ 1.50$. Postage charges paid. Write for pricis on crate lots of 6,000 or more.

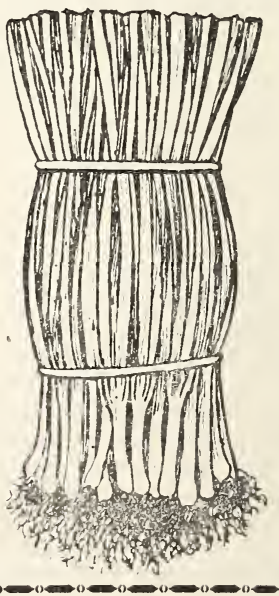


All Prices Quoted Below Include Postage

CULTURE-While a sandy loam is the best soil for the Carrot, any good land, if thoroughly and deterply worked, will produce satisfactory crops. When possible to do so, it is advisable to sow as early in the spring as the ground is fit to work. For field culture prepare the ground thoroughly and sow in drills 18 to 20 inches apart, using 2 to $3 \mathrm{lbs}$. of seed to the acre. Cover 1-2 to 1 inch deep and see to it that the soil is pressed firmly above the seed. Thin the smaller table sort to 5 or 8 to the foot and the field varieties 4 to 6 inches apart in the row.

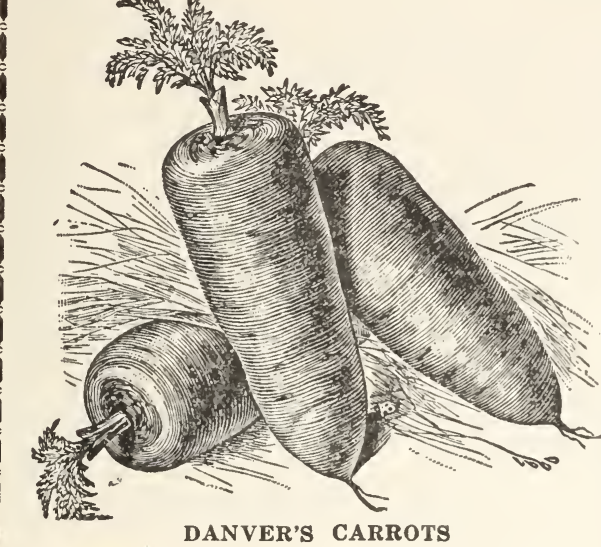

Danver's Half Long. (65 days.) A rich orange red variety, very smooth and handsome, producing very large crops. It is an excellent market variety. Tops are of medium size and coarsely divided. Roots taper to a blunt point. Flesh is sweet, crisp and tender. Will produce more bulk to the acre than the largest field varieties. Pkt. 10c, $1 / 4 \mathrm{lb}$. 35c, $1 \mathrm{lb}$. $\$ 1.00$.

Improved Long Orange. (80 days.) The most popular main-crop sort in cultivation. The roots are long and tapering, and of a deep orange color and free from side roots. One of the best winter sorts and is largely grown for table, market and stock. Pkt. 10c, $1 / 4$ lb. 35c, 1 lb. $\$ 1.00$.

\section{DANVER'S CARROTS}

Chantenay. (65 days.) An excellent half long, medium early variety. One of the best in quality and productiveness for the home or market gardener. Roots are thick, four and a half to five inches long, tapering slightly, smooth, deep golden orange in color. Pkt. 10c, $1 / 4 \mathrm{lb} .35 \mathrm{c}$, $1 \mathrm{lb} . \$ 1.00$.

\section{E L E R Y}

CULTURE-Sow in February. March or beginning of April in rows in fine, rich soil. Keep the seed bed well watered, as celery germinates very slowly. Transplant from June to August. Celery does best in a moist, mucky soil and in situations where plenty of water is abundant in the soil. One ounce sows about 100 feet and produces about 8,000 good plants. Prices include postage.

Improved White Plume. (120 days.) The favorite sort with most gardeners on account of its earliness and requiring very little earthing up. It blanches very easily, is of fine, attractive appearance. Pkt. 10c, oz. 25c, 1/4 lb. 90c.

Golden Self Blanching. (French Grown). This is the best self-blanching sort. It acquires a handsome, golden color without having to be hilled up, which makes it a valuable market sort. Pkt. 10c, oz. 75c, 1/4 lb. $\$ 2.50$.

Winter Queen. This is the best keeper of all late sorts; very solid and crisp. This variety is unsurpassed for market garden. Pkt. $10 \mathrm{c}$, oz. $25 \mathrm{c}, 1 / 4 \mathrm{lb}$. $90 \mathrm{c}$.

Easy Blanching. A new variety of great merit, dwarf and compact with light green foliage. The stalks are thick and solid and of large extra fine quality. Pkt. 10c, oz. 35c, 1/4 lb. $\$ 1.00$.

\section{KOHL-RABI}

Cultivation same as for cabbage, taking care to set plants no deeper than they stood in the seed bed and in hoeing, not to heap too much dirt about them. Keep weeds down and when the thickened stems above ground are 2 to 3 inches in diameter should be used at once, as they toughen with age.

Extra Early White Vienna. (60 days.) Pkt. $10 \mathrm{c}$, oz. $25 \mathrm{c}, 1 / 4 \mathrm{lb} .75 \mathrm{c}$.

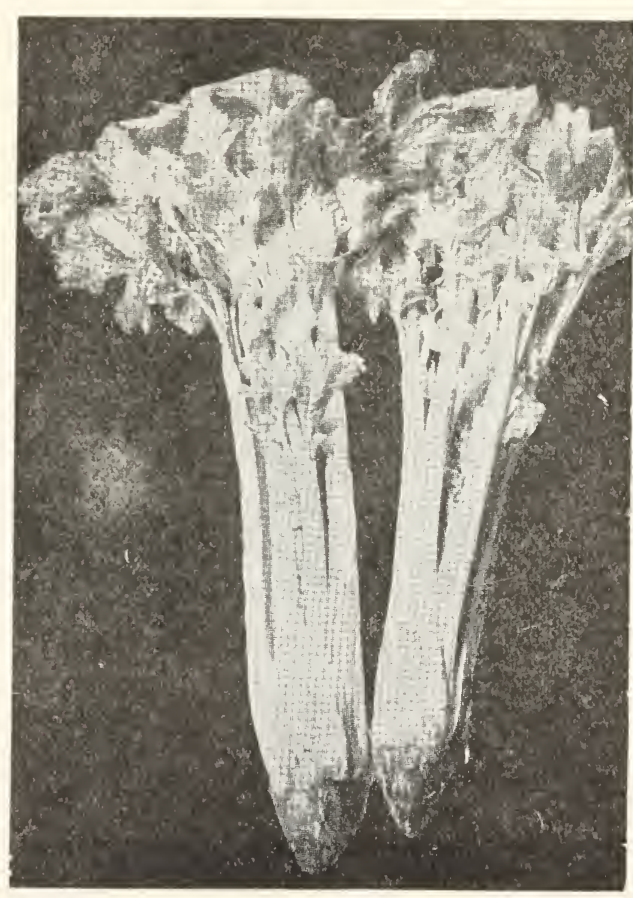

GOLDEN SELF-BLANCHING CELERY 


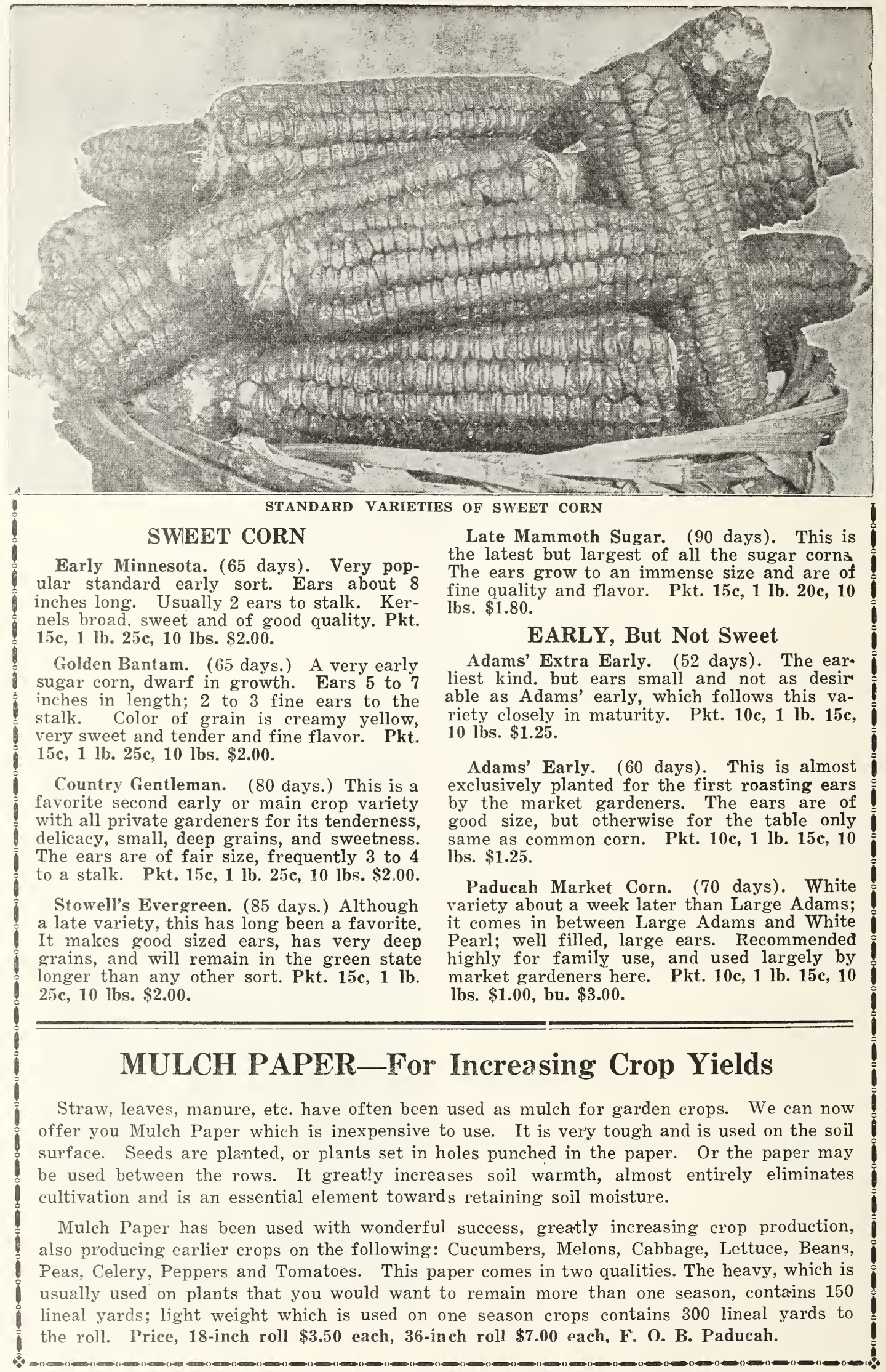




\section{EXTRA SELECTED CUCUMBERS}

CULTURE-For very early field crop plant in hot beds, in pots or small paper boxes, or in pieces of sod, grass side down so that they can be readily transplanted, or plant in the open ground as soon as the weather becomes settled warm, about the end of April or during May, in hills about 4 feet apart each way. The hills should be previously prepared by mixing a shovel of well-rotted manure or a small handful of fertilizer with the soil. For main field crop plant in May and put about ten seeds in each hill, and when all danger of insects is past, thin out to 4. For late pickling, plant in June or July.

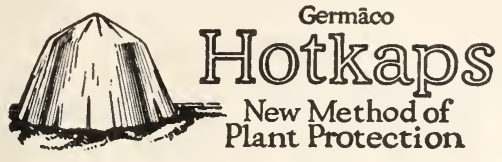

1

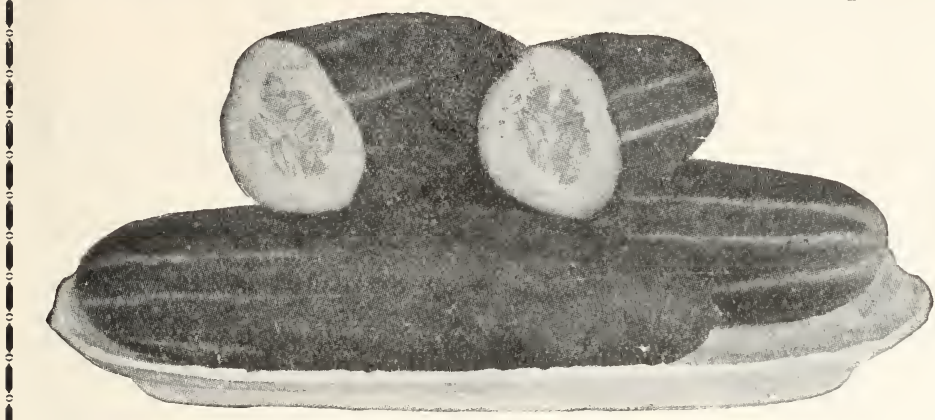

EARLY FORTUNE

Early Fortune. (65 days.) It grows large, uniform and regular, from 10 to 12 inches long and nearly one ideal shape. The color is an attractive rich dark, glossy green. Its attractive form and rich color surpass all other cucumbers. Early Fortune is one of the earliest cucumbers grown. It holds up well in shipping long distances. It bears abundantly and continuously throughout the entire season; large crisp fruit, which never loses its tenderness. Pkt. 10c, oz. 15c, 1/4 lb. $40 \mathrm{c}, 1 \mathrm{lb}$. $\$ 1.25$.

White Wonder. (70 days.) Color ivory white, fruit produced in clusters. Short and rounded at both ends. Pkt. 10c, Ounce $15 \mathrm{c}, 1 / 4 \mathrm{lb} .50 \mathrm{c}, \mathrm{lb} . \$ 1.50$.

Snow's Pickling. (65 days.) The best formed and most productive pickling sort. Early, square-ended and dark green. We have a selected strain of this variety and recommend it as the best cucumber for pickling. Pkt. 10c, oz. 15c, 1/4 lb. 35c, $1 \mathrm{lb}$. $\$ 1.00$. finest quality. When young, the cucumbers are in great demand for pickles; in fact, it is the standard sort for this purpose. Pkt. 10c, oz. $15 \mathrm{c}, 1 / 4 \mathrm{lb}$. $40 \mathrm{c}, 1 \mathrm{lb}$. $\$ 1.25$.

Early Cluster. (60 days.) Very early, fruit short chunky, small and borne in clusters in the center of the plant. Light green in color, very prolific. Pkt. 10c, oz. 15c, $1 / 4$ lb. 35c, 1 lb. $\$ 1.00$.

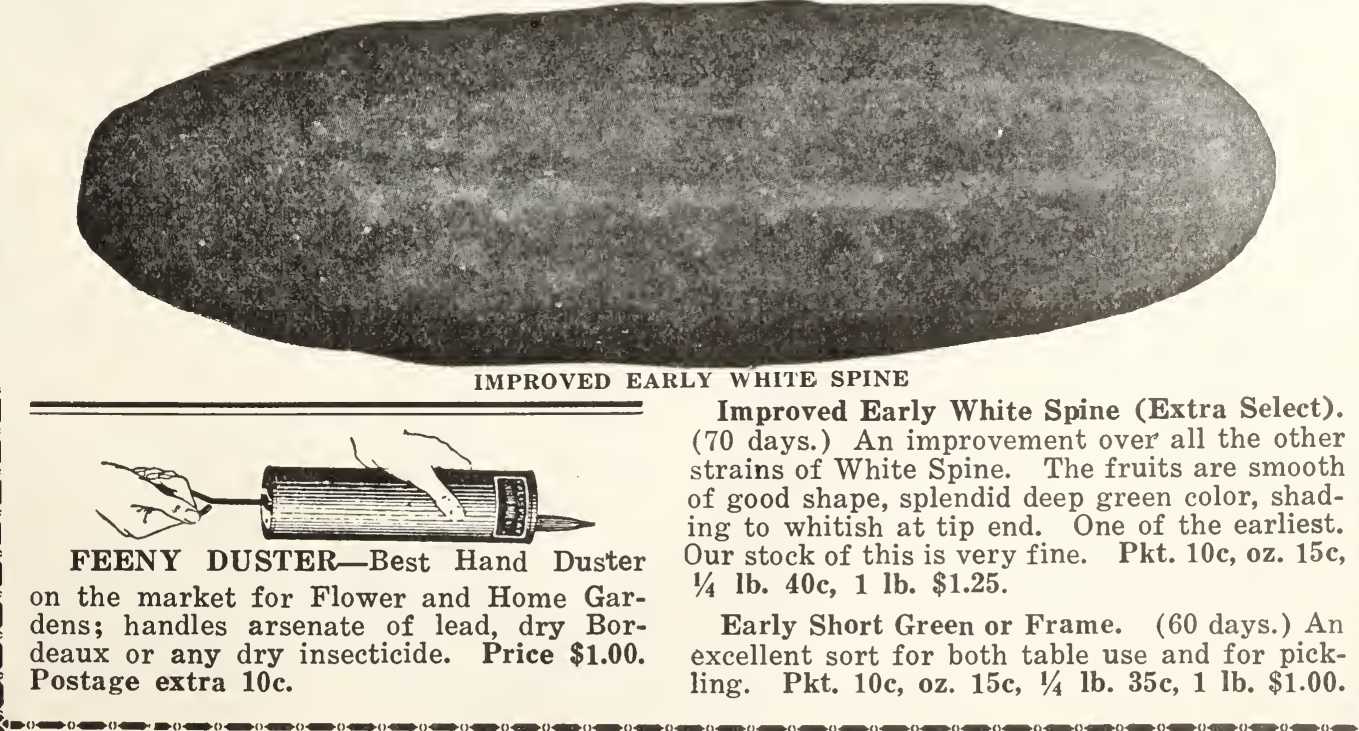

Woodruff's Hybrid. Extra early species of remarkable Has a long straight attractive shape with rich green color, the color stays green shipper. Also a fine greenhouse cucumber. We recom-

West India Gherkin. A small, burr-shaped variety. Always Green. (70 days.) Color beautiful dark green which is retained longer than Fruit 7 to 8 inches long, vigorous grower and good yielder. Pkt. 10c, oz. 15c. 1/4 lb. 40 c, 1 lb. $\$ 1.25$.

days.) Our carefully selected strain of this old-time popular garden favorite may be depended upon to produce true, dark green fruits, 10 to 12 dark green fruits, 10 to 12

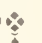




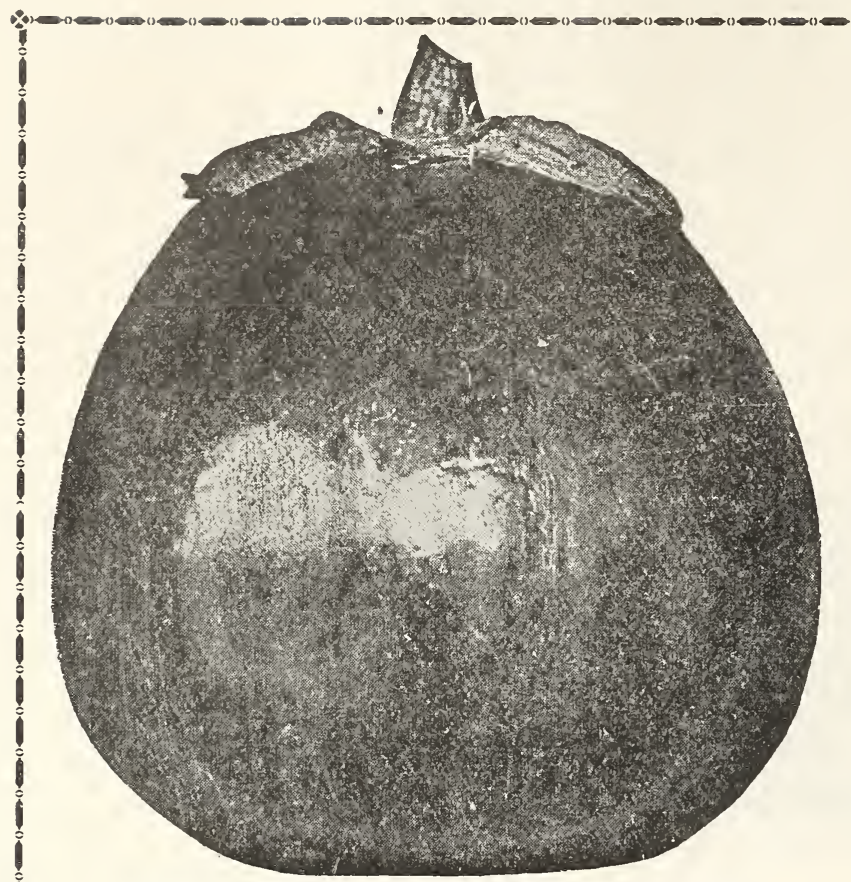

\section{ENDIVE}

Green Curled. (40 days.) Ornamental curled leaves of dark green, which blanch white and crisp. Pkt. 10 c, $1 / 4$ lb. 40c, lb. $\$ 1.25$.

\section{WATER CRESS}

Cress (Water). A hardy plant which can be grown in moist soil or along the edge of shallow running streams. Pkt. 10c, oz. 50c.

\section{GOURDS}

Dipper. Capacity varies from a pint to a quart, with handles 6 to 12 inches long. Pkt. 10c.

Fine Mixed. A collection of the most ornamental. Pkt. 10c.

Japanese Nest Egg. These exactly resemble the eggs of hens, making a capital nest egg. Pkt. 10c.

IMPROVED NEW YORK SPINELESS EGG PLANT

Calabash or Tipe Gourd. Pkt. 10c.

\section{EGG PLANT}

CULTURE-Sow in hotbed very early in the spring and transplant to very rich warm ground, setting them 2 to 3 feet apart. Hoe frequently and hill up gradually until they blossom. Egg Plant seed will not germinate freely without a strong, uniform heat, and if the plants are al: lowed to get the least chilled they seldom recover from the shock.

Improved New York Spineless. (130 days.) This is the standard variety everywhere. The eggs come early, are of large size, regular oval shape, and a fine deep purple in color. Pkt. 10c, 0z. 40c, $1 / 4$ lb. $\$ 1.25$.

Black Beauty. (125 days.) This variety is the earliest kind. Pkt. 10 c, oz. 40c, $1 / 4$ lb. $\$ 1.25$.

\section{COLLARDS}

Of particular value in the South. The Collard forms a mass of leaves on a tall stem. Improved in flavor by frost.

CULTURE-Sow like cabbage. Transplant when a few weeks old. Set a foot apart in rows. Cultivate frequently. Sow seed in June, July and August. One ounce of seed will grow 4,000 plants.

Georgia Southern. Blue stem. Pkt. 10c, 1/4 lb. 25c, 1 lb. 75c.

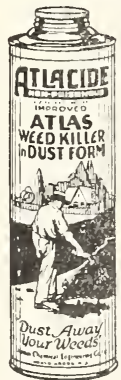

Atlacide Non Poisonous Weed Killer Duster exterminates all undesirable vegetation, without danger of poisoning humans or animals. Simply shake powder from can on the weeds and grasses to be killed. Especially recommended for obtaining weed-free driveways, paths, te n n is courts and gutters.

1-lb. DUSTER _-_-_50 Each (kills 100 sq. feet of weeds).

31/2-lb. DUSTER_-\$1.50 Each

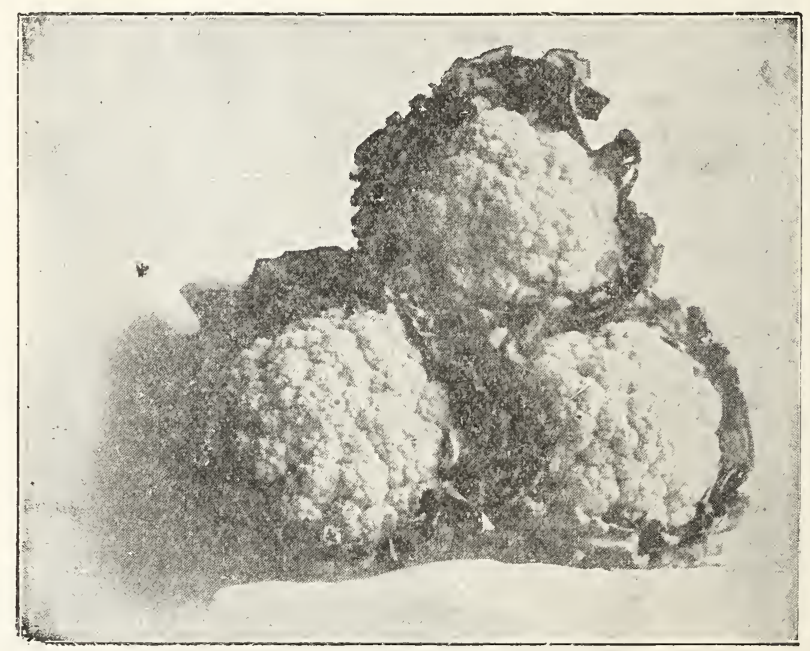

\section{EARLY SNOWBALL CAULIFLOWER} CAULIFLOWER

CULTURE-Cauliflower succeeds best when planted in hot beds during January or February and brought to maturity before the summer heat sets in. If properly hardened off, the plants are seldom injured if planted outside as early as the ground can be worked. Set them out in the richest soil avanable. They should stand two and a half feet apart each way. Keep them well hoed and bring the earth gradually up to the stems, watering freely in dry weather and protecting them from direct sun heat, especially dry weather and protecting
when they begin to head.

Early Six Weeks. Next to Snowball, it is the surest to head. Pkt. 25c, oz. $\$ 2.00$.

Early Snowball. An improved extra early strain of dwarf, compact growth. Is highly esteemed by market gardeners for its earliness and reliability as a sure header. It grows on a robust stem and produces magnificent white heads. Although one of the best for forcing under glass and cultivated principally for an early crop, it produces equally well for late planting. Pkt. 25c, oz. \$2.50. 
This should be in continuous supply in every private garden from early spring until late fall, and sowings should be made accordingly, using Black Seeded Simpson for earliest crop, followed with Grand Rapids, May King, Big Boston and Improved Hanson. Then in July, August and September, sow Hanson for late crop.

One ounce sows 300 feet of drill; 3 pounds to one acre. One ounce produces 2,500 plants An acre set in plants requires about 50,000 set $8 \times 15$ inches.

\section{All Prices Quoted Below Include Postage}

CULTURE-For winter forcing, make sowings from September to February. Sow the curled varieties abou every four weeks the Head or Cabbage sorts about 6 weeks apart. As one crop is cut out another can be planted. For early spring crop sow under glass in January or February and transplant in the spring. For succession sow at intervals of three or four weeks until end of April. For fall planting sow the hardy varieties in September and transplant, when large enough, to cold frames 9 inches apart.

\section{CURLED OR LOOSE HEAD VARIETIES}

\section{Yopp's F a vorit e} Curled. (45 days.) A la $\mathrm{rge}$ clustering nonheading variety. Light golden leaves not as curled as Grand Rapids. The earliest variety of curled lettuce, fine flavor. Pkt. 10c, 1/4 lb. 35c, 1 lb. $\$ 1.25$.

Early Curled Simpson. (40 days.) The standard cutting or loosehead variety. It is earlier than any of the heading kinds. Used extensively for sowing in cold frames and is also largely grown in the open ground, especially in small home gardens. It forms a close, compact mass of curled yellow green leaves. Pkt. 10 c, $1 / 4$ lb. 35 c, 1 lb. $\$ 1.25$.

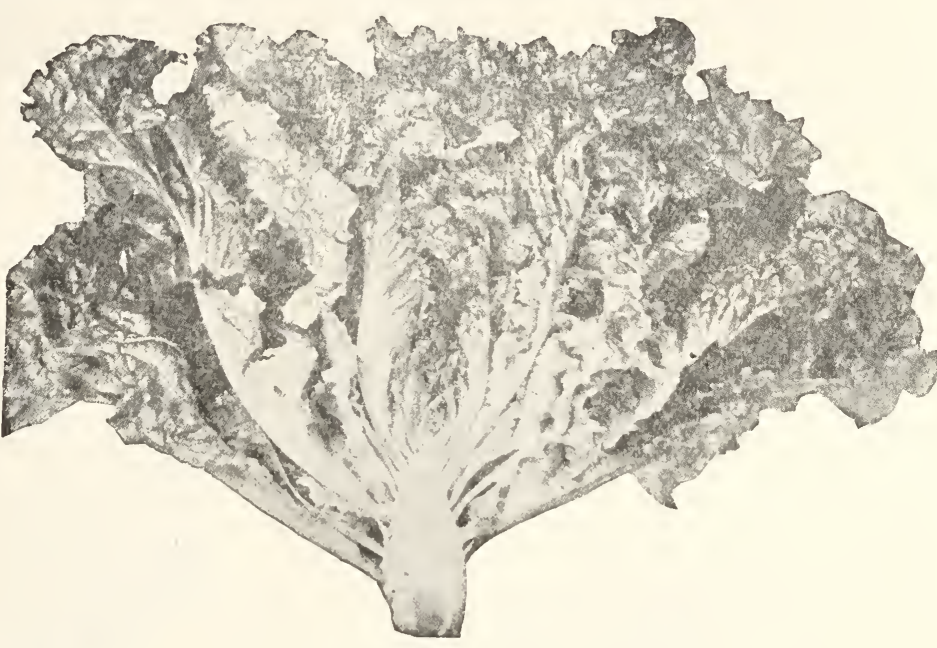

BLACK SEEDED SIMPSON LETTUCE

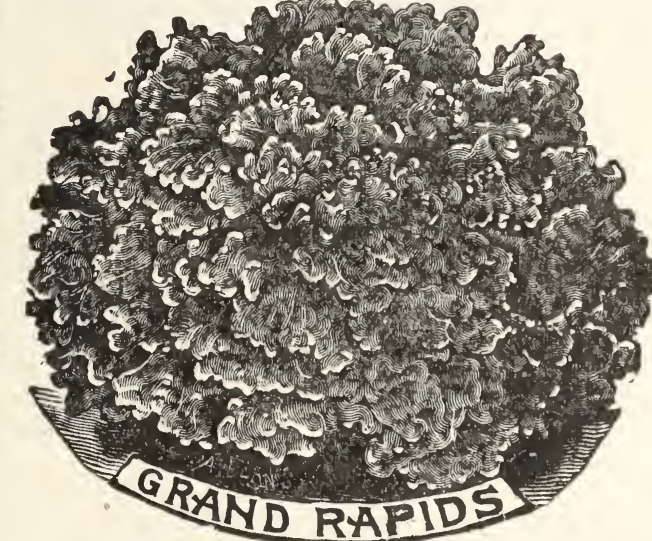

Grand Rapids. (45 days.) This variety is especially adapted to greenhouses or forcing in frames, and is generally recognized as the standard of forcing lettuce. The plant is upright, forms a loose head of large, green leaves, crimpled at the edges, not liable to rot, and stands some days after ready to cut indoors or outdoors. Pkt. 10c, $1 / 4$ 35c, 1 lb. \$1.25.

Prize Head. (45 days.) The leaves are very large, crimpled, bright green, tinged with brownish-red, and are exceedingly tender, crisp and sweet, forming a large, loose head. Pkt. 10c, 1/4 lb. 35c, 1 lb. \$1.25.

Black Seeded Simpson. (40 days.) A very popular sort with market gardeners. Forms a large loose head; has nearly white curly leaves; thin, exceedingly tender and of good quality. Splendid for growing under glass and early planting outside. Oz. 10c, 1/4 lb. 35c, 1 lb. $\$ 1.25$.

\section{PULVERIZED SHEEP MANURE}

Every season we have a large demand for Pulverized Sheep Manure. This has been treated for the purpose of destroying all the weeds in it. We especially recommend it for dressing lawns, golf courses and small

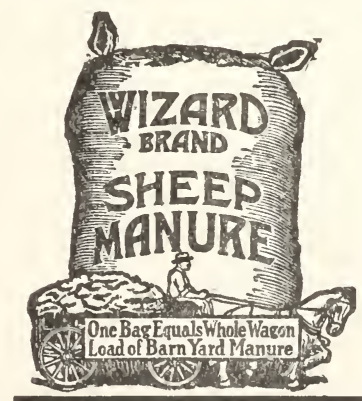
gardens. It a lso makes an excellent fertilizer for soaking in water and using the liquid for house plants. It comes in packages nicely packed and the odor is not at all objectionable. It comes ready for use. 5 lbs. $30 \mathrm{c}, 10$ lbs. 50c, 25 lbs. 75 c, 100 lbs. \$2.25.

When you want the best field seed grown, Order "YOPP'S CHIEF BRAND." "Always Best Seed Grown." 


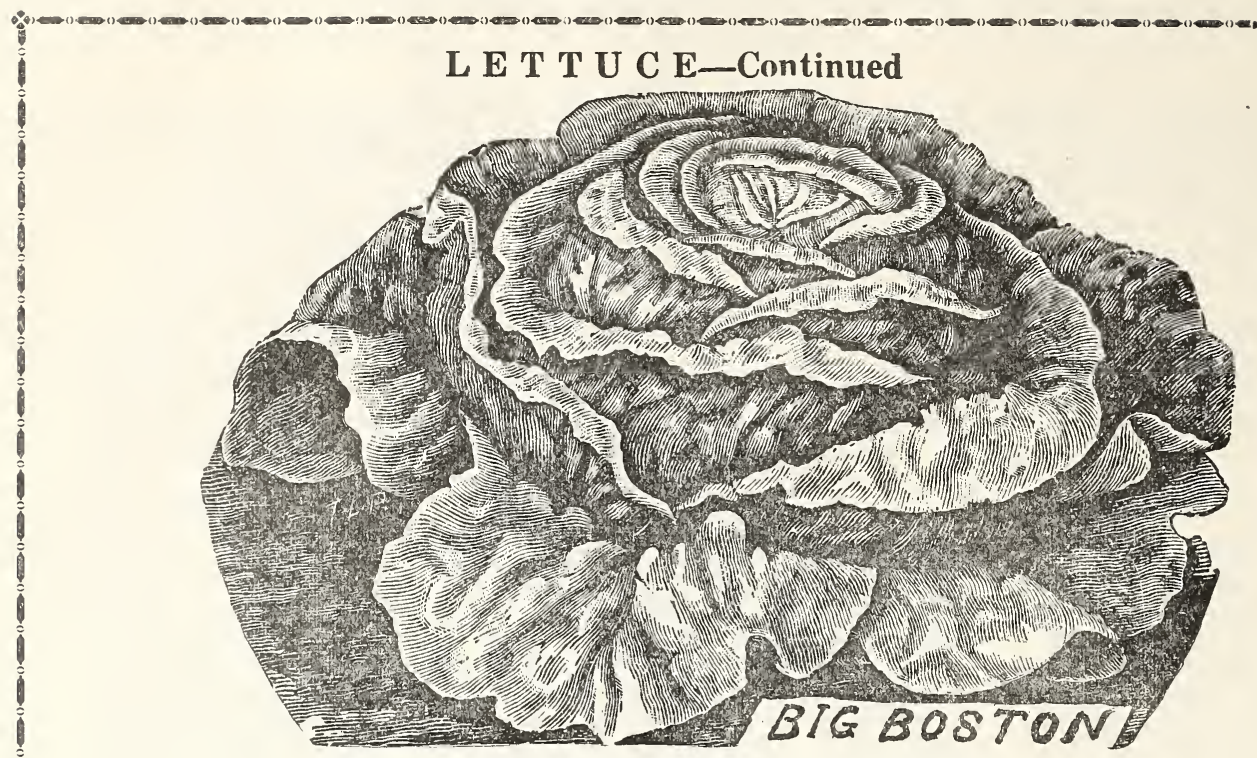

\section{HEADING OR CABBAGE VARIETIES}

Big Boston. (50 days.) This variety is identical in color, shape and general appearance with the famous Boston Market Lettuce, but is double the size. It is about one week later in maturing, but its solidity and greater size of head will make it a most valuable sort. A most desirable variety for forcing in cold frames or for open ground planting. Pkt. 10c, 1/4 lb. 35 c, 1 lb. $\$ 1.25$.

Improved Hanson. (55 days.) One of the best of the summer varieties. Color, light green with crimpled edges; heads extremely large, solid and fine appearance, hence popular for market. Quality a little coarse, but on account of its reliable bearing is one of the best for summer. Pkt. 10c, $1 / 4$ lb. 35c, 1 lb. $\$ 1.25$.

New York or Wonderful (Los Angeles Market.) A very large cabbage-head late variety of lettuce. Heads are globular, very large and well blanched. Leaves broad, fairly blistered, crumpled. Color dark green. This lettuce is now being shipped all over the country and known by produce dealers as Iceberg. Pkt. 10c, oz. 20 c, $1 / 4$ lb. 65 c, 1 lb. $\$ 2.25$.

All Seasons. (55 days.) One of the best of all head lettuces, standing the hot sun better than any other sort. It is slow to seed. Handsome; good sized. It's color is light green. Pkt. 10c, 1/4 lb. 35c, 1 lb. $\$ 1.25$.

Yopp's "Chief Brand" Seeds are of high germination and the cleanest seed grown and are used by all farmers in this section of the country. Write for prices before buying elsewhere.

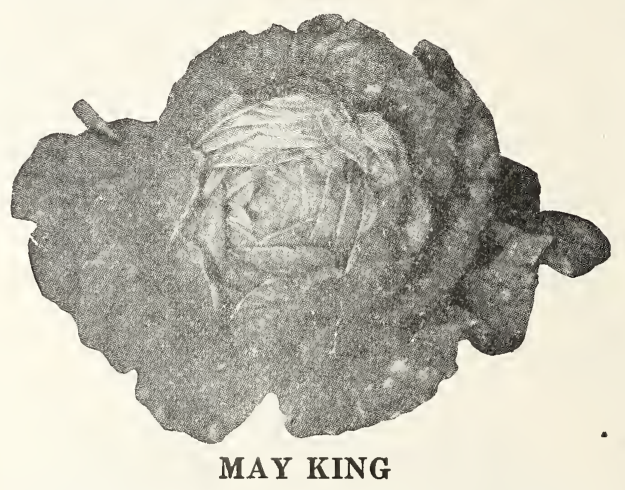

May King Early Head Lettuce. (45 days.) Plant this for the first early head lettuce. It is equally good for outdoor planting or forcing. Very crisp and tender, and for quality, melts in the mouth like butter. Its growth is extremely rapid and its fine large heads are ready in advance of any other heading variety. Pkt. 10c, $1 / 4$ lb. 35c, 1 lb. $\$ 1.25$.

Chicken Lettuce. Not for table use, but a good green food for chickens. Large bunches of leaves. Pkt. 10c, oz. 15c, 1/4 lb. 35c.

Special prices on larger quantities.

\section{PAPER PLANT POTS}

With these you can start your plants in the house or under glass and transplant to the open when danger of frost is over without disturbing the root growth of the plants.

Packed 250 in box, per box $\$ 1.50$. Postage extra, 25c.

Write for prices on larger quantities. 


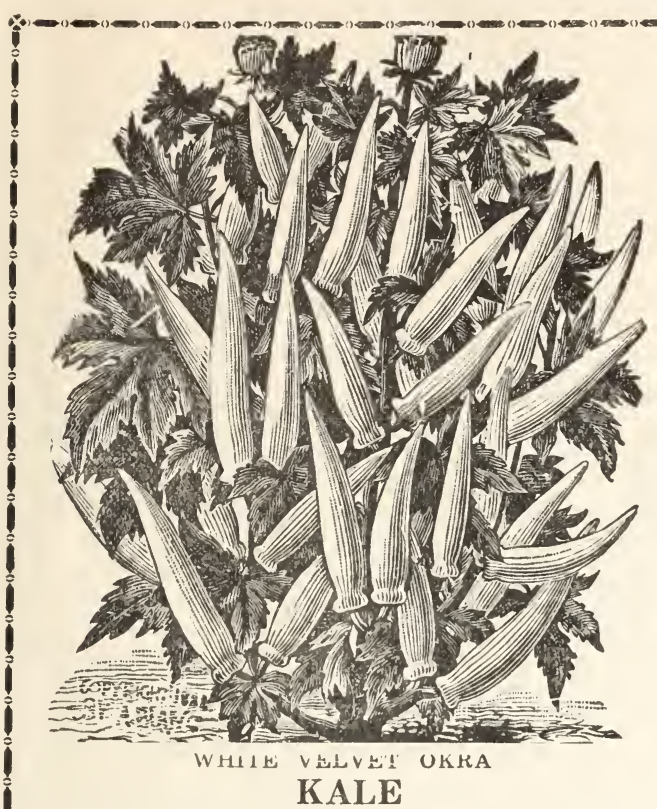

Kale makes excellent greens for winter and spring use. Sow from May to July and cultivate the same as cabbage. For early spring use, sow in September and protect during winter.

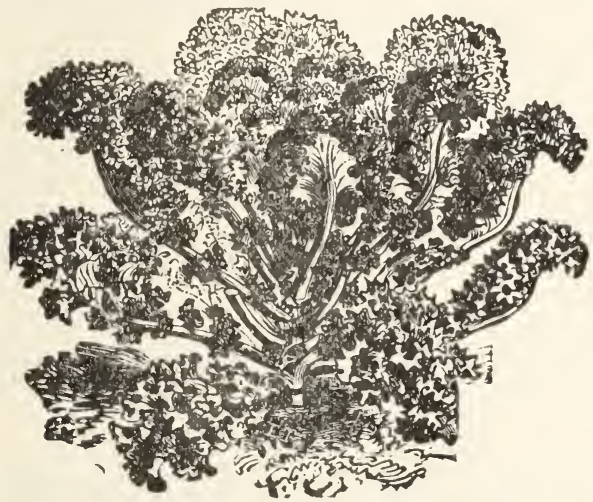

SIBERIAN KALE

Siberian. (60 days.) Pkt. 10c, 0z. 15c, 1/4 lb. $25 \mathrm{c}, 1 \mathrm{lb}$. $75 \mathrm{c}$.

Dwarf Scotch Green. (55 days.) Pkt. 10c, oz. $15 \mathrm{c}, 1 / 4$ lb. $30 \mathrm{c}, 1 \mathrm{lb} .85 \mathrm{c}$.

Blue Scotch. (55 days.) Pkt. 10c, oz. 15c, $1 / 4$ lb. 35c, 1 lb. $\$ 1.00$.

Mushroom Spawn. 1 brick will spawn about 10 square feet. Mushroom beds may be made in dry warm cellar or in any building free of frost. The spawn should be broken in pieces about 2 inches square placing them 6 inches apart in the bed, then cover with 2 inches of rich soil. We furnish complete cultural instructions with each order. 1 Brick $35 \mathrm{c}, 3$ Bricks for $\$ 1.00$. Postage prepaid.

We frequently receive orders for garlic seed, but we can only supply bulbs. $1 / 4 \mathrm{lb}$. $15 \mathrm{c}, 1 \mathrm{lb}$. 40c.

\section{LEEK}

One ounce will sow about 100 feet of drill.

Large Flag. Hardy and productive. The standard variety. Pkt. 10c, oz. 25c.

\section{OKRA}

CULTURE-Sow in May, as soon as the ground has become warm, in drills 3 feet apart, covering the seed one inch Thin out the plants until they stand a foot apart. Give rich soil and good cultivation. Gather the pods while young and tender.

White Velvet. $(60$ days.) White Variety, dwarf with round, smooth pods, free from ridges and seams, a nd not prickly to the touch. Very prolific and early. Pkt. 10c, $1 / 4$ lb. $20 \mathrm{c}, 1 \mathrm{lb} .50 \mathrm{c}$.

Dwarf Green. (50 days.) The best of the $\mathrm{d} w$ a $\mathrm{rf}$, long, green-pod varieties. It is very productive and the pods are tender and of the finest quality. Pkt. $10 \mathrm{c}, 1 / 4 \mathrm{lb} .20 \mathrm{c}$, lb. 50c.

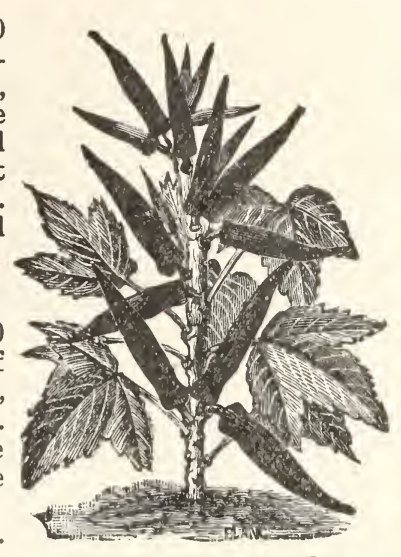

BLOCK'S FAVORITE

Block's Favorite. (50 days.) The plants make a dwarf and stocky growth. Matures early and yields a tremendous crop of pods. They are fiberless while young. Pods very slim, do not get hard and of intense green color. Pkt. 10c, $1 / 1$ lb. $20 \mathrm{c}, 1 \mathrm{lb}$. $60 \mathrm{c}$.

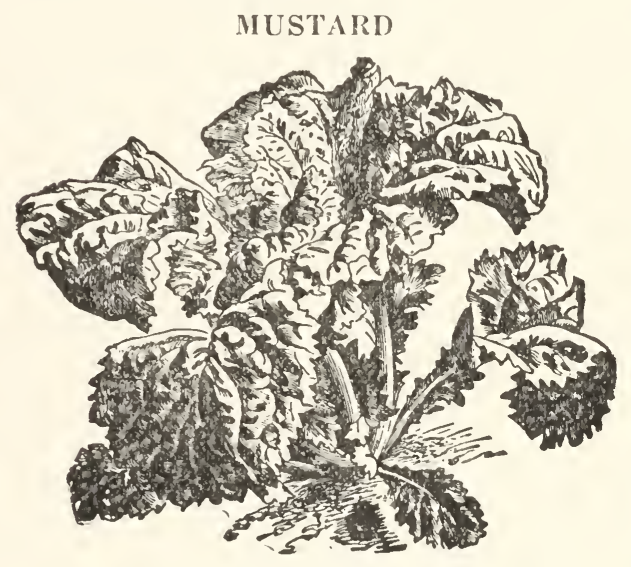

GIANT SOUTHERN CURLED

Florida Broadleaf. Leaf smoother and broader than Chinese. Oz. 10c, 1/4 lb. 25c, lb. 75c.

Giant Southern Curled. This variety is a great favorite in the South for ganishing. Very large dark green leaves, the edges of which are finely curled. Oz. 10 c, $1 / 4$ lb. 20c, 1 lb. $50 \mathrm{c}$.

Chinese Broadleaf. The leaves are twice the size of the ordinary White Mustard while the flavor is sweet and pungent. Oz. 10c, $1 / 4$ lb. 20c, 1 lb. 50c.

\section{HORSE RADISH \\ (Malener Kren)}

Horse Radish produces no seed, but is grown from pieces of the root; per $100 \$ 1.25,1,000$ for $\$ 10.00$. 


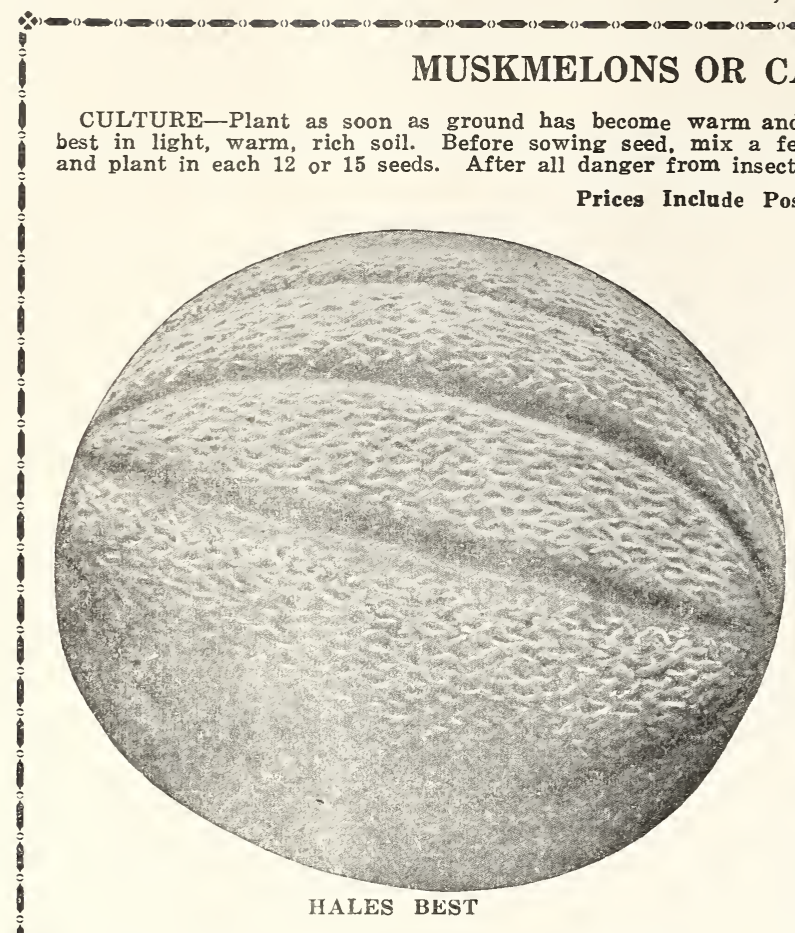

Hales Best. (70 days.) A new variety of the Rocky Ford type Muskmelon. This is a leading variety with the shippers of the Imperial Valley in California and remarkably early Melon, Salmon Flesh, exceptionally thick, very small seed cavity. Hales best is the finest Muskmelon of this type, largest size. Pkt. $10 \mathrm{c}, 0 \mathrm{z}$. $15 \mathrm{c}, 1 / 4$ lb. $40 \mathrm{c}, 1$ lb. $\$ 1.25$.

Gold Lined Rocky Ford. (75 days.) An improved Rocky Ford Melon more closely netted and slight orange tinge next to seed cavity. Green flesh, of medium size. Thick flesh with small seed cavity. Unsurpassed for flavor. Pkt. 10c, oz. 15c, $1 / 4 \mathrm{lb} .40 \mathrm{c}, 1 \mathrm{lb}$. $\$ 1.25$.

Large Hackensack. (85 days.) Fruit large, round, flattened at the ends; deeply and irregularly ribbed, coarsely and heavily netted. Flesh green, thick and of fine quality. Pkt. 10c, $1 / 4$ lb. 35c, 1 lb. $\$ 1.00$.

Pollock's No. 10-25. (80 days.) Improved Rocky Ford with salmon flesh. Unusually small seed cavity, well netted. Pkt. 10c, $1 / 4$ lb. $40 \mathrm{c}, 1$ lb. $\$ 1.25$.

Netted Rock. (75 days.) A famous melon on Paducah market. Slightly larger than Rocky Ford, a better shipping melon. Very thick, solid, green flesh. Fine grained and sweet. Pkt. 10c, oz. 15c, $1 / 4$ lb. 60c, $1 \mathrm{lb}$. $\$ 2.00$.

Champion Market. (80 days.) Fruit large round or slightly oval, slightly ribbed and covered with dense netting. Flesh green, of medium texture, very thick and sweet. Pkt. 10c, 1/4 lb. 35c, 1 lb. $\$ 1.00$.

Rocky Ford. (75 days.) This famous melon is well-known everywhere, and has been the standard shipping variety. Pkt. $10 \mathrm{c}, 1 / 4 \mathrm{lb} .30 \mathrm{c}, 1 \mathrm{lb} .90 \mathrm{c}$.

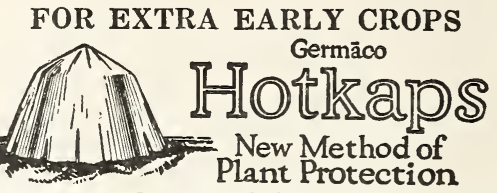

Prices: 1 roll containing 1000 Hotkaps weighing $20 \mathrm{lbs}$. $\$ 11.50$. 5 rolls, per roll $\$ 11.00$.

Hotkap Setter \$2.50. Postage or express extra. See Page 30.

Hearts of Gold. (80 days.) One of the finest types of the early Orange Fleshed Melons. Excellent shipper and equally good for market or home gardens. Pkt. $10 \mathrm{c}, 1 / 4$ lb. $50 \mathrm{c}, 1 \mathrm{lb}$. $\$ 1.50$.

Burrell's Gem. (80 days.) A truly delicious melon for home use. It is about the size and shape as the Rocky Ford, but has rich yellow flesh of delicious flavor, solid and a most desirable shipping sort. Seed cavity small. Pkt. 10c, 1/4 lb. 35c, 1 lb. $\$ 1.00$.

Osage. (75 days.) This melon is one of the best for family use. Its flesh is a salmon color, and has a remarkably sweet and spicy flavor, extremely thick and delicious to the rind. Pkt. $10 \mathrm{c}, 1 / 4$ lb. $40 \mathrm{c}, 1 \mathrm{lb}$. $\$ 1.25$.

Tip Top. (85 days.) For splendid eating qualities this melon has certainly been rightly named, for it is one of the most deliciously flavored melons in existence. It grows to a large size and has a thick, orange flesh. Pkt. $10 \mathrm{c}, 1 / 4 \mathrm{lb}$. 50c, $1 \mathrm{lb}$. $\$ 1.50$.

Banana. Long and slender, growing the shape of a banana; flesh deep salmon color; fair quality; grows from 18 to 24 inches long. Pkt. 10c, $1 / 4$ lb. 50c, 1 lb. $\$ 1.50$.

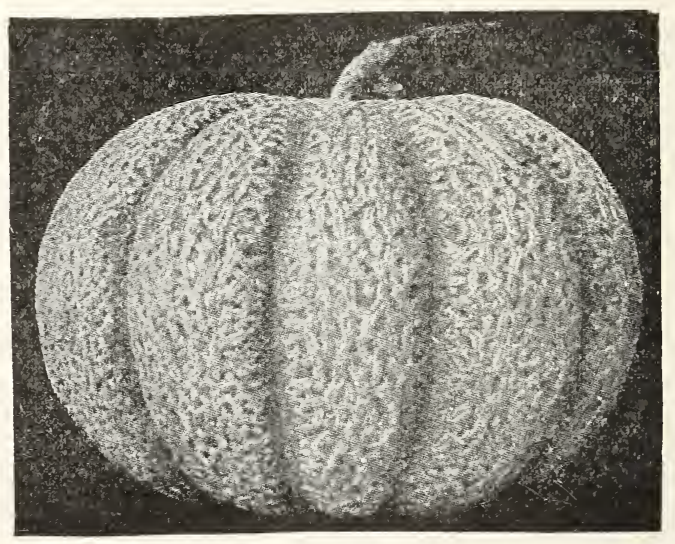

EXTRA EARLY HACKENSACK

Extra Early Hackensack. (70 days.) An early selection from the old Hackensack, maturing from a week to ten days earlier; somewhat smaller and not so deeply ribbed, but otherwise similar to the old type. Pkt. 10c, 1/4 lb. $40 \mathrm{c}, 1$ lb. $\$ 1.25$. 


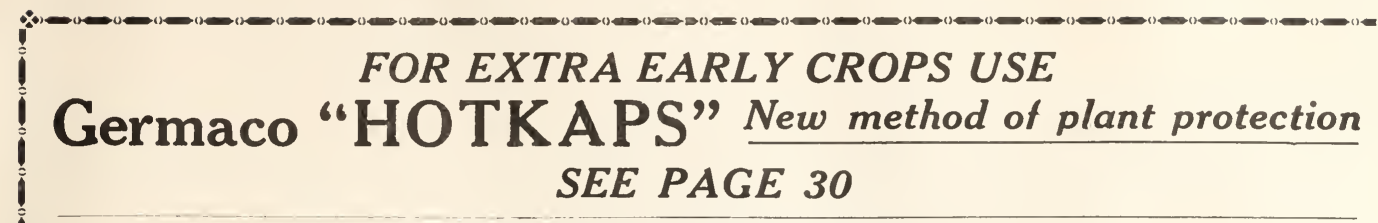

\section{WATERMELON-Selected Seed}

CULTURE-Watermelons do best in light, well-drained soils. To get good melons, it is essential that the plants have a good start, therefore the seed should be put in just as soon as the weather is really warm and settled. Prepare hills about 8 feet apart, working into the soil a $\mathrm{n}$ abundance of well-rotted manure and in these plant the seed, thinning out to 2 or 3 plants in each hill.

One ounce plants 30 hills; 3 lbs. to the acre. Plant early in May, or, for late use, in June. All Prices Quoted Below Include Postage

Irish Gray. (90 days.) Long, thick, uniform; rind yellowish gray, interwoven with thread-like veins, flesh sparkling bright red, sweet; one of the best shippers; seeds white; average size 30 lbs. Pkt. 10c, $1 / 4 \mathrm{lb} .30 \mathrm{c}, 1 \mathrm{lb} . \$ 1.00$.

Harris' Earliest. (80 days.) An extra early melon of excellent quality; slightly oval with broad light and dark stripes. Flesh bright red and tender. Seed black. Pkt 10c, $1 / 4$ lb. $30 \mathrm{c}$, 1 lb. $\$ 1.00$.

Georgia Rattlesnake.

days.) Long gray, with light green stripes; excellent shipper, vines vigorous and productive flesh red and sweet. Also known as striped Gypsy. Average wgt. 25 lbs. Pkt. 10c, 1/4 lb, 30c, 1 lb. $\$ 1.00$.

Kleckley Sweet. (85 days.) No other melon has ever attained such popularity for home use and nearby markets; eating quality leaves nothing to be desired; meions medium in size. Oblong, dark green skin, thin rind. Pkt. 10c, $1 / 4$ lb. $30 \mathrm{c}, 1$ lb. $\$ 1.00$.

Tom Watson. (90 days.) Attains a larger size than any of the long green melons, frequently growing to 50 or $60 \mathrm{ibs}$. The rind is thin but tough: flesh deep red. Pkt. 10c, 1/4 lb. $30 \mathrm{c}, 1 \mathrm{lb}$. $\$ 1.00$

Cream Fleshed. The best of the cream or yellow fleshed variety. Pkt. 10c, 1/4 lb, 30c, 1 lb. $\$ 1.00$.

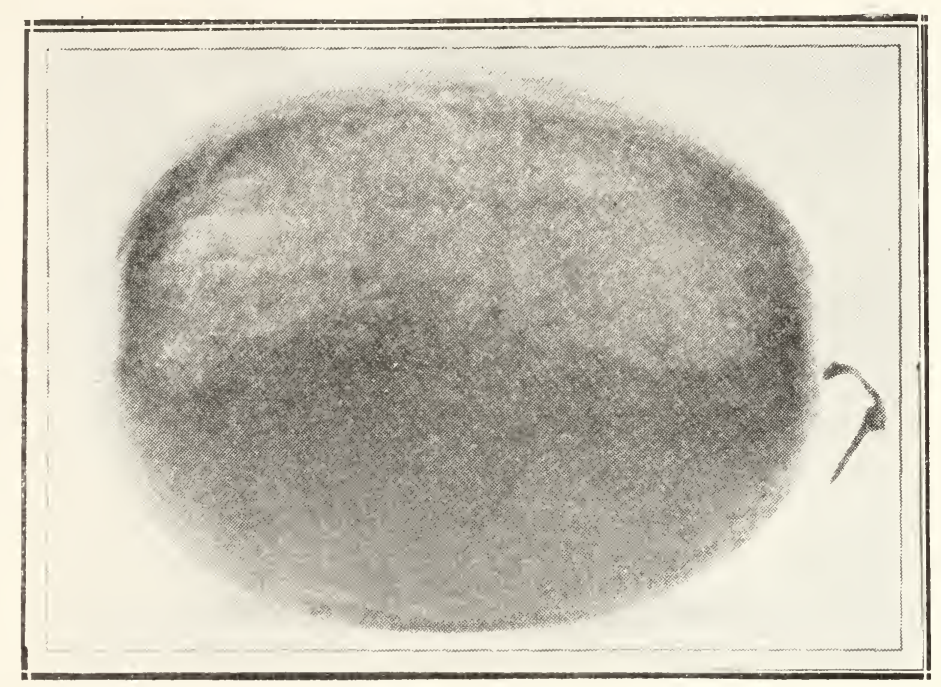

STONE MOUNTAIN

Stone Mountain. (90 days.) Sometimes known as Lipsey or Dixie Belle. Largest of all, almost round, has very few seeds and the most delicious melon ycu ever tasted. Price, Pkt. 10c, oz. $15 \mathrm{c}, 1 / 4$ lb. $50 \mathrm{c}, 1 \mathrm{lb}$. $\$ 1.50$.

Halbert Honey. (90 days.) Equal in flavor and appearance to the Kleckley Sweet, but more regular in form and much more productive. Average length, 18 to 20 inches. Color of rind a clear, glossy deep green. Flesh a beautiful crimson. Pkt. 10c, $1 / 4$ lb. $30 \mathrm{c}, 1 \mathrm{lb}$. $\$ 1.00$.

New Excel. (90 days.) Very large and good shipping mel-

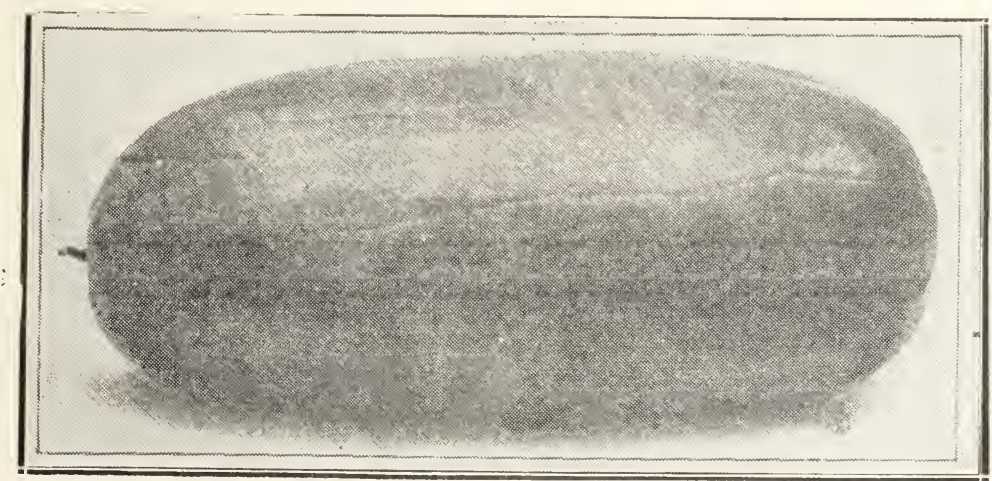

PERFECTION

Perfection. (85 days.) An improved Kleckley Sweet. This wonderfcl new watermelon has all the good qualities of the Kleckley Sweet, but is very much larger in size, often weighing up to 50 pounds. Rind glossy, dark green, thin but unusually tough, so is a fine melon to ship. Flesh dark red, very sweet, free from fiber. Pkt. 10c, oz. 20 c, $1 / 4$ lb. 40 c, 1 lb. $\$ 1.25$. on, fruit long, dark green in color with an irregular faint striping, covered with fine veining of darker sha:le. Rind hard and tough. Mid-season, fle sh red, crisp and fine quality. Pkt. 10c, 1/4 lb. $30 \mathrm{c}, 1$ lb. $\$ 1.00$.

Wonder. (90 days.) It possesses _ a - wonderful flavor, the color is dark green, shape oblong and rind, good shipping melon Price, Pkt. 10c, oz. $15 \mathrm{c}, 1 / 4$ lb. $30 \mathrm{c}, 1 \mathrm{lb}$. $\$ 1.00$.

Florida Favorite. days.) A dark and light green mottled melon, of beautiful appearance; oblong in shape. The flesh is bright crimson, cri $=p$ and deliciously swe t. Early. Pkt. 10c, 1/4 lb. $30 \mathrm{c}, 1$ lb. $\$ 1.00$. 


\section{CHOICE ONION SEED}

Sow in March or April outdoors. For large onions, at the rate of 5 or 6 lbs. per acre. For sets, 40 to 60 lbs. per acre. For Pickle Onions, 1 oz. sows 150 feet. 15 lbs. per acre.

CULTURE-For large, fancy onions: Sow in January or February in hot beds or trays. As soon as the weather opens and the sets are the size of a goose quill, transplant in rows 12 inches apart and 4 to 6 inches between the onions. For sets: Sow in February or March in rows 10 to 12 inches apart, in smooth, clean well prepared land. Keep free of all weeds and cultivate as often as necessary, depending on condition of growth to produce small sized sets.

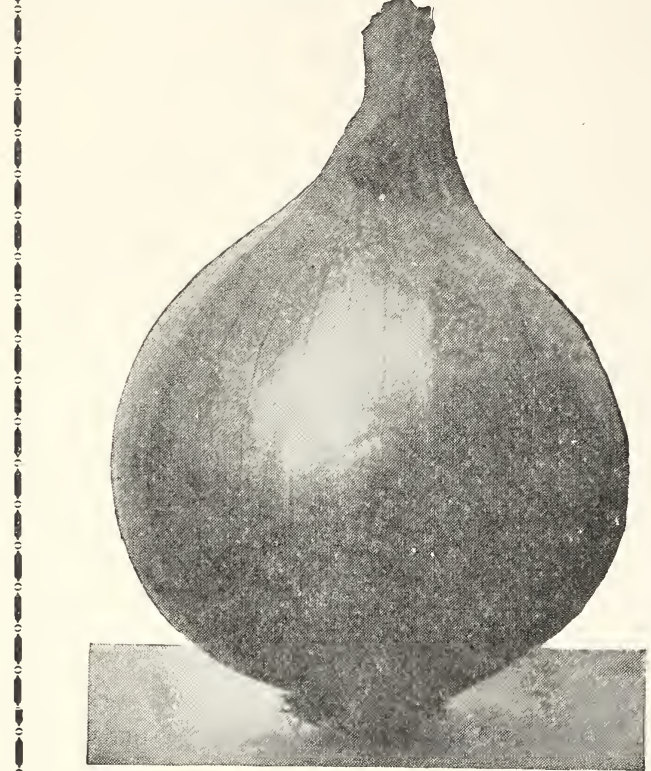

SOUTHPORT RED GLOBE

Southport Red Globe. (130 days.) A fine, large, globe-shaped onion of mild flavor. It is a good keeper excellent for main crop. Pkt. 10c, oz. 20c, 1/4 lb. 65c, Ib. \$2.25.

Sweet Spanish. A very large globe shaped light yellow Onion. An exceptional fine shipper. Very mild and a good keeper. Pkt. 10c, oz. 25c, $1 / 4$ lb. 75 c, lb. $\$ 2.50$.

Ebenezer or Japanese Onion. A very fine round yellow onion. One of the best keepers. Pkt. 10c, oz. 20c, $1 / 4$ lb. 65c, lb. $\$ 2.25$.

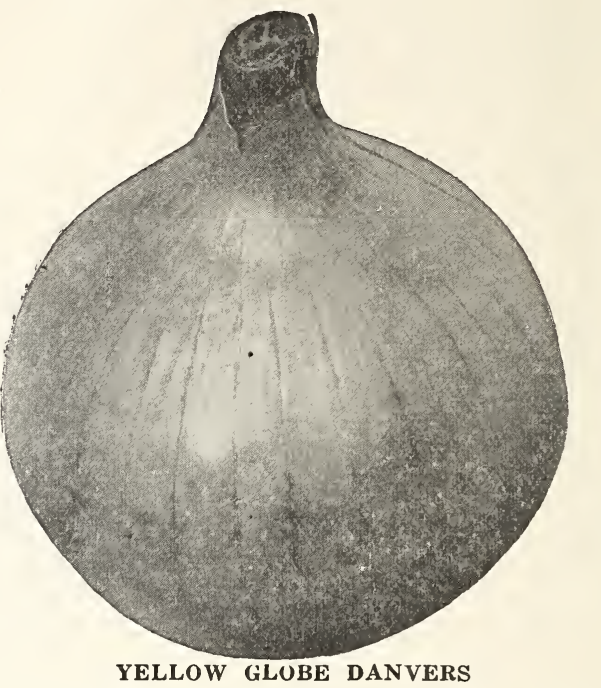

Yellow Globe Danvers. (115 days.) This is the most popular of all the yellow sorts. It is the kind most used by Chicago market gardeners. In all markets where a yellow sort is used, it takes the lead. Pkt. 10c, oz. 20c, 1/4 lb. $60 \mathrm{c}, \mathrm{lb} . \$ 2.00$.

Yellow Bermuda. (70 days.) A flat shaped, light straw colored onion. Each year this onion has grown in popularity and many of the larg'e growers of the South will plant no other kind. Pkt. 10c, oz. 30c, 1/4 lb. 90c, lb. $\$ 3.00$.

Crystal Wax. (70 days.) Very desirable for family use. Flavor mild and pleasant. Skin silvery white. Pkt. 10c, oz. 40c, 1/4 lb. $\$ 1.25$, lb. $\$ 4.50$.

Mammoth Prizetaker. (90 days.) Grows to an immense size and for fall marketing is unexcelled. Handsome bulbs of a rich yellow color and fine globe form. Pkt. 10c, oz. 20c, $1 / 4$ lb. $60 \mathrm{c}, 1 \mathrm{~b} . \$ 2.00$.

\section{FOR ONION IPLANTS, SEE PAGE 8.}

\section{ONION SETS THE QUICKEST WAY TO GROW BUNCH ONIONS.}

Onion Sets are subject to market changes. We are glad to quote by letter at any time.

Onion Sets from Seed. These are the product of seed and are used for "Green Onions," or to produce large onions, which they do much quicker than can be grown from seed.

Yellow Bottom Sets. Market Prices.

White Bottom Sets. . Market prices.

Red Bottom Sets. Market Prices.

Ebenezer or Japanese Bottom Sets. Market Prices.
Onion Sets for Fall Planting.

Egyptian or Perennial Tree Onion Sets. Also called Winter Top Sets. Never form a large bulb. Especially for green onions for Spring and Fall. Very productive. Market Prices.

Potato Onion Sets. Sometimes called Hill Onion. Valuable for bunching or early crop of bulbs. Smallest sets make fine, large bulbs. Bulbs, when planted, multiply, each producing from 6 to 12 stalks for bunching. Sets, lb. $12 \frac{1}{2}$ c, $10 \mathrm{lb}$. lots $10 \mathrm{c}$ lb. Postage extra. 


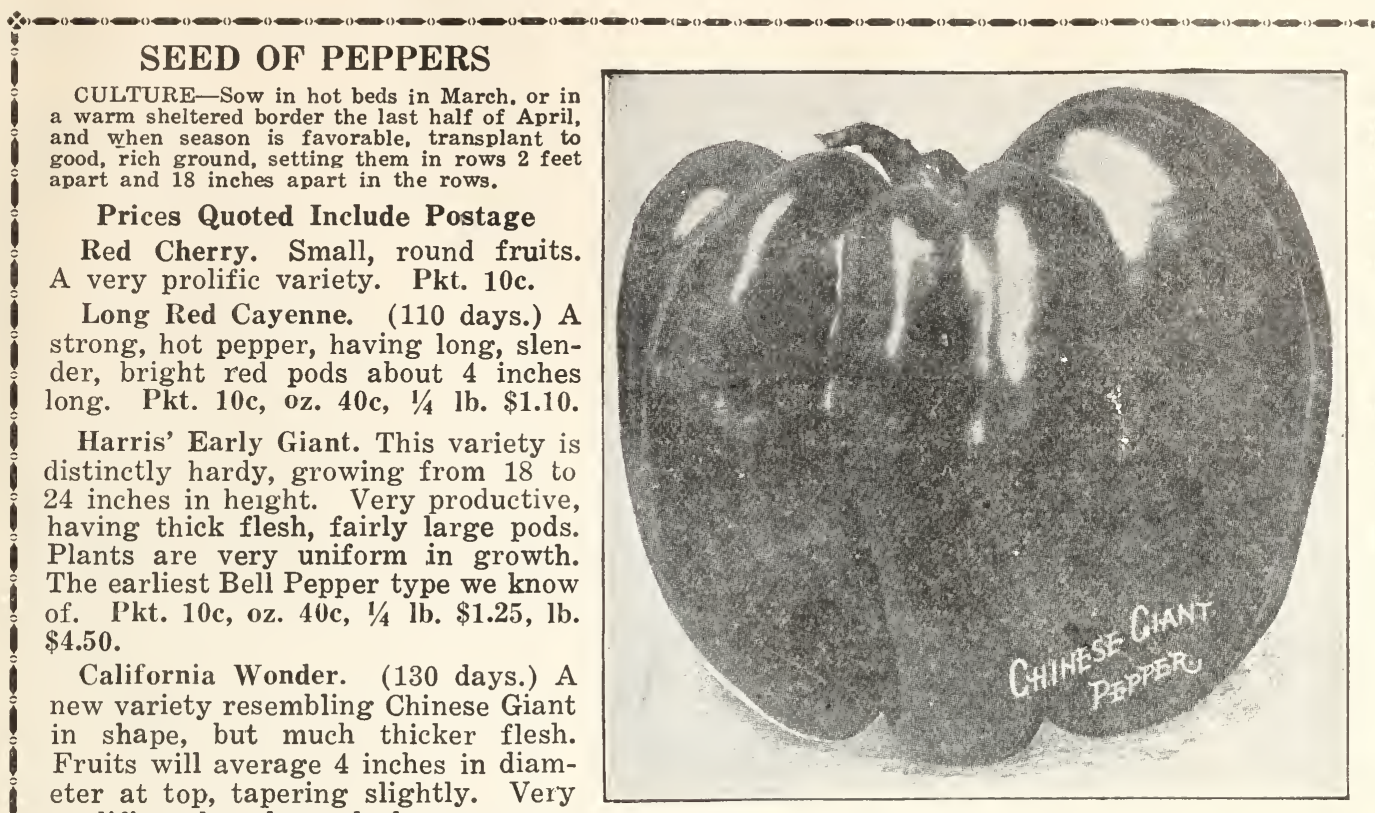

eter at top, tapering slightly. Very

prolific, color glossy dark green turn-

ing to crimson. Pods very heavy. Pkt. 10c, oz. 60c, 1/4 lb. $\$ 2.00$.

Chinese Giant. (140 days.) The largest and finest mild red pepper grown. The plants are vigorous and stocky in growth, well branched and thickly set with enormous fruits. It ripens early and is immensely productive. Fruits are of thick and blocky form, and most brilliant, glossy scarlet. IPkt. 10c, oz. 50c, 1/4 lb. $\$ 1.50$.

Royal King. (130 days.) A beautiful pep per similar in shape to Bullnose but much larger and flesh thicker. It is exceptionally mild. Color of fruit green when young, bright glossy red color when matured. Pkt. 10c, oz. 35c, 1/4 lb. $\$ 1.00$.

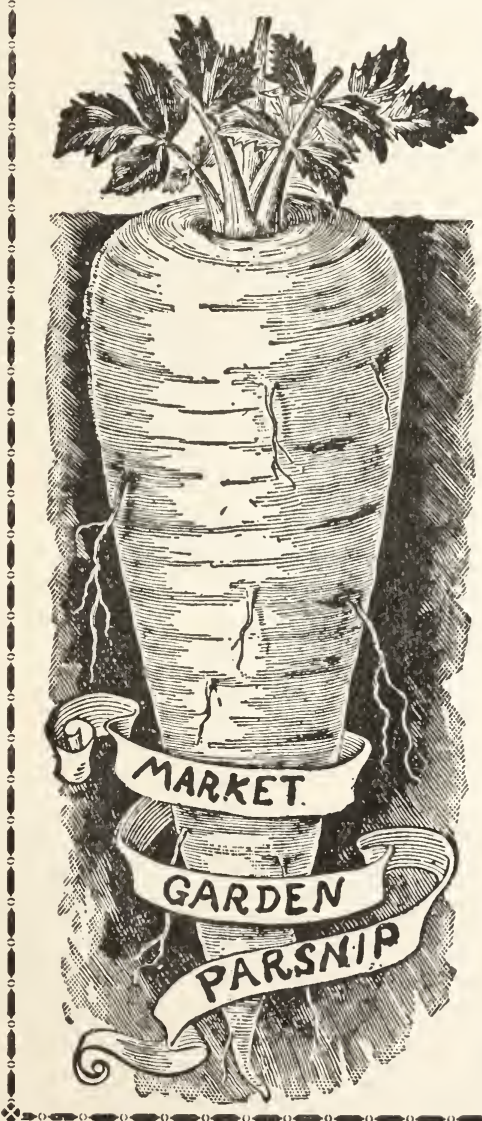

Bell or Bullnose. (120 days.) Early, prolific and popular. Flesh thick but somewhat hot. Pepper is medium and bright red. Pkt. 10c, oz, 35c, $1 / 4$ lb. $\$ 1.00$.

Pimento. Is very thick fleshed, heart-shaped, smooth, mild crimson variety; much used for salads. Pkt. 10c, oz. 40c.

Golden Queen. (120 days.) The largest of the sweet yellow pepper. Similar in size to Royal King, mild in flavor and golden yellow when ripe. Pkt. 10c, oz. 30c, 1/4 lb. $85 \mathrm{c}$.

\section{PARSLEY}

CULTURE-Soak seed in water for a few hours and sow in rich soil early in spring in rows a foot apart and cover lightly. Parsley is slow to germinate and is sometimes 3 to 4 roeks in coming up. One ounce will sow 150 feet of drill.

Double Curled. The best and most improved strain. It is beautifully curled and crimped, and is the best for garnishing and flavoring. It makes an ornamental plant for edging walks. Pkt. 10c, oz. 15c, $1 / 4$ lb. 35c.

Plain. Leaves flat, deeply cut, but not curled;Pkt. 10c, oz. $15 \mathrm{c}, 1 / 4 \mathrm{lb}$. $35 \mathrm{c}$.

\section{PARSNIP}

CULTURE-A rich, sandy loam, deeply worked, is the best for parsnips. Sow in April in drills 1 inch apart, covering lightly. Parsnip seed is very slow in germinating, es pecially when the ground is dry. When the plants are 2 inches high, thin out to 4 or 5 inches apart. One ounce of seed will sow 200 feet of drill. Five or six pounds to the acre.

Parsnips remain in the ground all winter without protection and can be dug for use as required until they begin to run to seed in the spring. They are altogether a most desirable winter vegetable, and should be much more largely grown than at present.

Sugar Hollow Crown. (90 days.) This is an old standard variety. Smooth skin, tender and well flavored. It is good either for table use or stock. Pkt. 10c, 1/4 lb. 25c, 1 lb. 75c.

Improved Guernsey. (90 days.) An improved strain which has given general satisfaction. The roots do not grow so long as those of the Hollow Crown, but are of greater diameter and more easily gathered. Pkt. 10c, 1/4 lb. 25c, 1 lb. 75c. 
NORTHERN-GROWN SEED PEAS
CULTURE-The extra early varieties should be sown as early in the spring as the ground can be worked. In
this latitude they can frequently be planted in February Continue sowing for a succession every two weeks
until June, then stop until the last of August, when a go crop can be obtained by planting the extra early sorts
for all use. In the home garden sow double rows 6 to 8 inches apart and 2 to 4 inches deep, with double rows
2 or 3 feet apart. Varieties growing 2 feet high or more should be supported with brush. The early kinds do
best in a light, warm soil. Later varieties require a rich loam, including clay, and should be planted deeper
than others.
Postage on Packets Free. For postage on pounds, see inside cover page.
EXTRA EARLY DWARF VARIETIES

Laxton's Progress. (56 Days.) The earliest large podded dwarf sweet pea. Height 18 inches. In season four days earlier than Laxtonian. Pods 4 inches long, broad and pointed, deep green in color, containing 8 large, dark green peas of high quality. Pkt. 15c, lb. 30c, 5 lbs. $\$ 1.25,10$ lbs. $\$ 2.00$.

Laxtonian. (60 Days.) A large podded dwarf variety; height 11/2 feet, pods and vine dark green; pods about $3 \frac{3}{4}$ inches long, containing 6 to 8 large dark green peas. Excellent quality. Pkt. 15c, $1 \mathrm{lb}$. 30c, $5 \mathrm{lb}$. $\$ 1.25,10 \mathrm{lb}$. $\$ 2.00$.

Little Marvel. (60 Days.) Height 14 inches. Foliage and pods very dark green. Pods about 3 inches long, containing six to eight very dark green peas of high quality. They are very productive; a fine variety for the market gardeners. Pkt. 15c, 1 lb. 30c, 5 lbs. $\$ 1.25$, 10 lbs. $\$ 2.00$

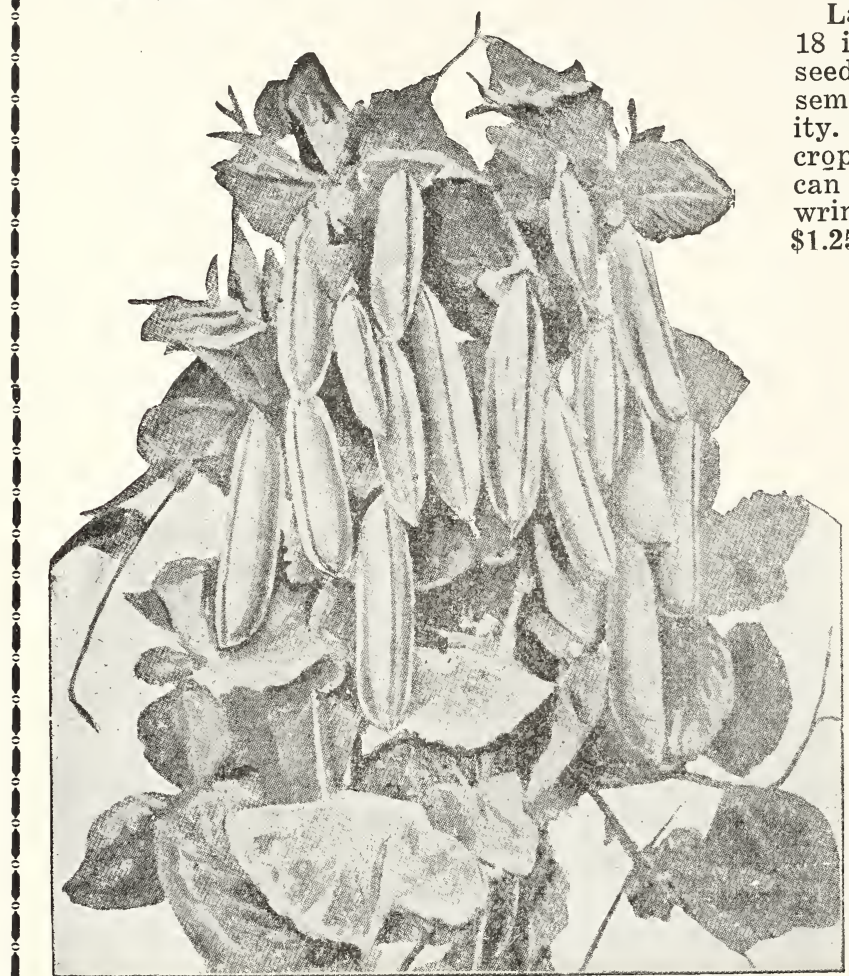

Laxton's Superb. (60 Days.) Height 18 inches. A hardy semi-wrinkled, blue seeded, extra early pea. The pods are semi-broad, deep green and of good quality. Desirable for market gardeners first crop. The seed being practically smooth, can be planted out earlier than the wrinkled sorts. Pkt. 15c, $1 \mathrm{lb}$. 30c, 5 lbs. $\$ 1.25,10$ lbs. $\$ 2.00$.

\section{SECOND EARLY VARIETIES}

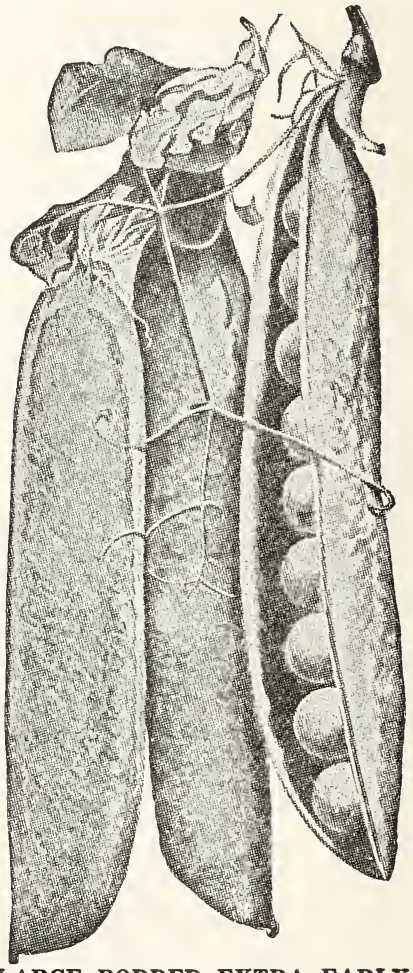

LARGE PODDED EXTRA EARLY

Large Podded Extra Early. Practically all the pods can be gathered at one or two pickings. Pkt. 15c, 1 lb. 25c, 5 lbs. $\$ 1.00,10$ lbs. $\$ 1.60$.

First and Best. (50 Days). Early, productive, and hardy, with strong, vigorous vine, which is light in color and uniform in growth, $2 \frac{1}{2}$ feet in height. Pkt. 15c, 1 lb. 25c, 5 lbs. \$1.00, 10 lbs. \$1.60.

Alaska. (50 Days). (21/2 ft.). A well kuown popular early variety. Pkt. 15c, 1 lb. 25c, 5 lb. \$1.00, 10 lbs. $\$ 1.60$.

Days). Larğe podded early pea, bearing more pods than any other variety. This new pea is ready for market about a week after the Extra Early. The vines are about 30 inches high, bearing an abundance of well-filled pods. The peas are of the very finest quality. Pkt. 15c, 1 lb. 25c, 5 lb. $\$ 1.00$, 10 lbs. $\$ 1.60$ 


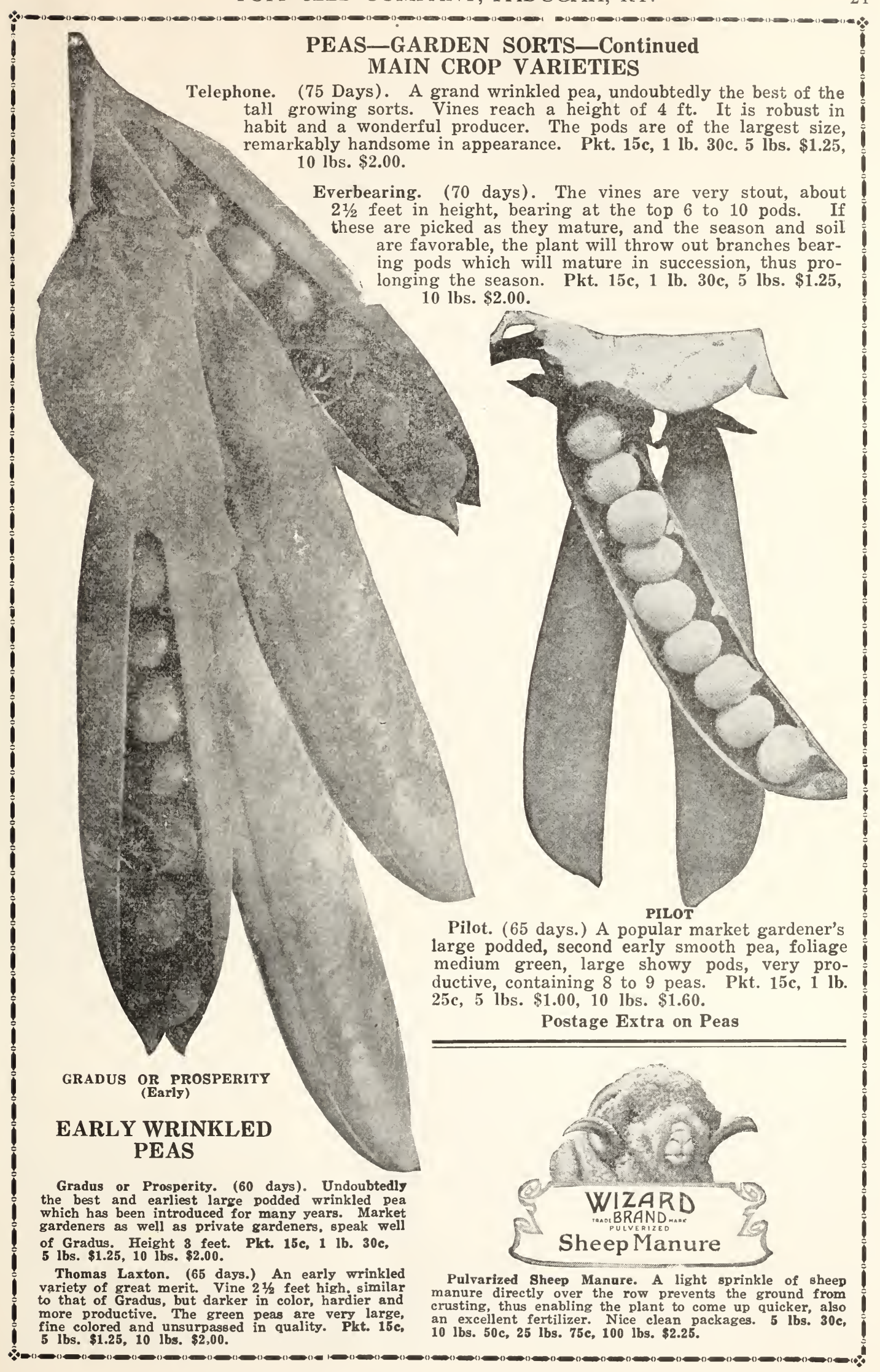




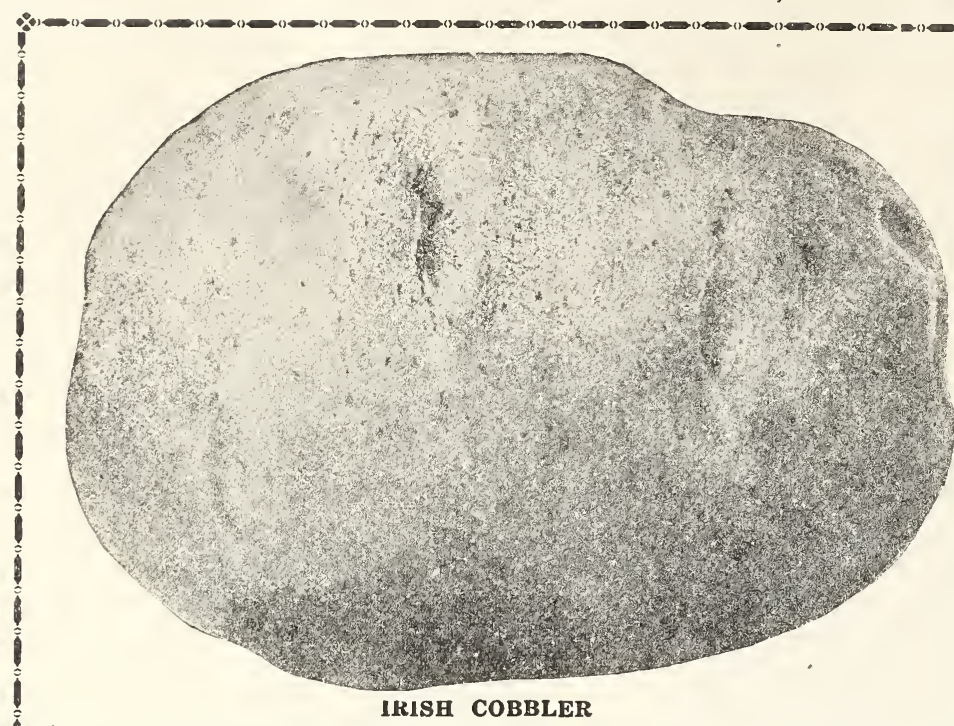

\section{SEED POTATOES}

CULTURE-A sandy loam. reasonably rich in organic matter is considered the very best soil for potatoes. However, any soil that is light and easily worked and contains a good supply of plant food will grow potatoes successfully. It is not advisable to apply fresh manure just before the tubers are planted. Fresh manure, besides causing a number of diseases on the tuber, contains too large a supply of nitrogen, which produces too rank a grow $t h$ at. the expense of the tubers.

Certified Seed Irish Potatoes. When you purchase genuine State Certified Potatoes, you get stock that has been inspected by an authorized state agent which assures you that this stock is free from serious diseases, and straight one variety. A state certification tag on each bag of Certified Potatoes. We have Irish Cobblers, Bliss Triumph and Early Ohio in Certified stock. Prices quoted on request.

Early Ohio. Favorite variety among gardeners everywhere and practicularly well suited to light or loamy soil, but succeeds well anywhere. Tubers are oval, have few eyes, smooth white skin, slightly flushed with rose and of exceptional quality.

Irish Cobbler. This has become one of the general favorites in all localities for early as well as late planting. The particular features which impress our many growers are the general thriftiness of the vines, combined with a remarkably large yield of fine, most at tractive, pure white-skinned potatoes. The tubers are of both fine appearance and quality.

Bliss' Triumph. One of the earliest and largely planted by truckers and gardeners for early crop, being mostly shipped to Northern markets, and is highly recommended. Potatoes round, with deeply idented eyes, and of pink skin.

Burbank. Of the late Northern sorts, this is more largely used than any other. It is of good size, oblong shape, and an excellent yielder. The flesh is white, and is very mealy, and of fine flavor.

Iiural New Yorker. A valuable variety of large size, very smooth and a great cropper. In quality it is unexcelled. It is the best late keeper and is highly recommended. Their large, handsome appearance makes them more profitable than any other sort. Market prices will be quoted on all seed potatoes upon application.

\section{gEED POTATO TREATMENT}

Irish Potatoes: All Seed Potatoes should be treated to prevent any possible disease It is a very simple and easy matter, and by doing this the crop can be increased considerably. Potatoes should be treated before cutting.

1. Solution, one ounce Corrosive Sublimate to seven and one-half gallons of water. Soak first lot in this solution for one and one-half hours and dry. Second lot, one and three-fourths hours, third lot for two hours and then discard solution.

2. For treating large quantities, use two pints Formaldehyde to each thirty gallons of water: heat to a temperature of 118 to 122 degrees F. and soak seed two minutes. Cover for one hour and dry.

Sweet Potatoes: Use one ounce of Corrosive Sublimate to seven and one-half gallons of water. Soak seed five to ten minutes and dry. Treat two lots and add one-eighth ounce of Corrosive Sublimate for each successive lot to be treated. After ten lots have been treated, make up a new solution.

\section{SWEET POTATOES}

Our seed is grown in this county and this market has a splendid reputation of having the finest and best sweet potatoes in this country. We can supply the following varieties in A pril: Florida Yams or Nancy Hall, and Porto Rico. We can furnish Nancy Hall or Florida Yam plants. Prices on both seed stock and plants on request.

\section{PUMPKIN SEED}

CULTURE-Plant the seed as soon as the ground becomes warm, in hills 8 to 10 feet apart each way, or in fields of corn about every fourth hill. Plant at the same time as the corn.

One ounce plants 20 to 30 hills; 2 to 3 pounds per acre.

Tennessee Sweet Potato. Medium sized, pear-shaped; slightly ribbed; color, cream white, sometimes lightly striped with green. Pkt. 10c, 0z. 15c, $1 / 4$ lb. 35c, 1 lb. $\$ 1.00$.

Japanese Pie. A high quality pumpkin of Japanese origin. The flesh is very thick, of a rich salmon color, fine grained, dry and sweet; seed cavity small. Pkt. 10c, oz. 15c, $1 / 4$ lb. 35c, 1 lb. $\$ 1.00$.
Large Yellow Field. A good stock variety, planted chiefly among corn; one of the largest and most attractive pumpkins grown. Pkt. $10 \mathrm{c}, 1 / 4 \mathrm{lb}$. 15c, $1 \mathrm{lb}$. 40c, 5 lbs. $\$ 1.50,10 \mathrm{lbs}$. $\$ 2.50$.

Mammoth. This is the very best genuine strain of the true mammoth pumpkin. Fruits grow to enormous size, sometimes reaching 2 feet or more in diameter, 50 to 100 pounds in weight. Pkt. 10c, oz. 15c, 1/4 lb. 50c, lb. $\$ 1.50$. 
CULTURE-Radishes to be crisp and tender, must be grown quickly. This requires a light, rich and finely pulverized soil. Sow thinly in drills 10 inches apart and thin the plants to stand 2 inches apart so the bulbs will rave ample room for development. When sown in frames they must have plenty of ventilation or they will grow all leaves and very small bulbs. Sow the winter varieties during July and August.

\section{Prices Include Postage}

One ounce sows 100 feet of drill; 10 to 12 pounds to the acre. For forcing, sow in January or February in frames. Outdoors from February to June. For late use, from July to September. Early sorts are ready for the table 21 to 30 days from sowing.

\section{EXTRA EARLY TURNIP VARIETIES}

Early Sparkler White 'Tipped. (22 days.) The outer skin is bright crimson color, with white tip; flesh pure white. Ouı strain of this variety is superior to mos1 stocks offered, making a nice, globeshaped, clean root, with no lateral roots. It has very small top and grows much quicker than the ordinary strain of White Tip Scarlet. Pkt. 10c, $1 / 4$ lb. 25c, 1 lb. 80c.

Bicolor-Transplanted Stock. This new Radish introduced to the trade two year's ago. An increasing demand on some markets for Raddish with a larger portion of white than Sparkler prompted our grower to select a breed and type of which the white extends from the tip up to the middle of the root, or even a little farther. Upper half is a vivid scarlet sharply marked. In shape it is quite similar to our Sparkler. A raddish of very attractive appearance which has already proved to be a favorite with truckers.

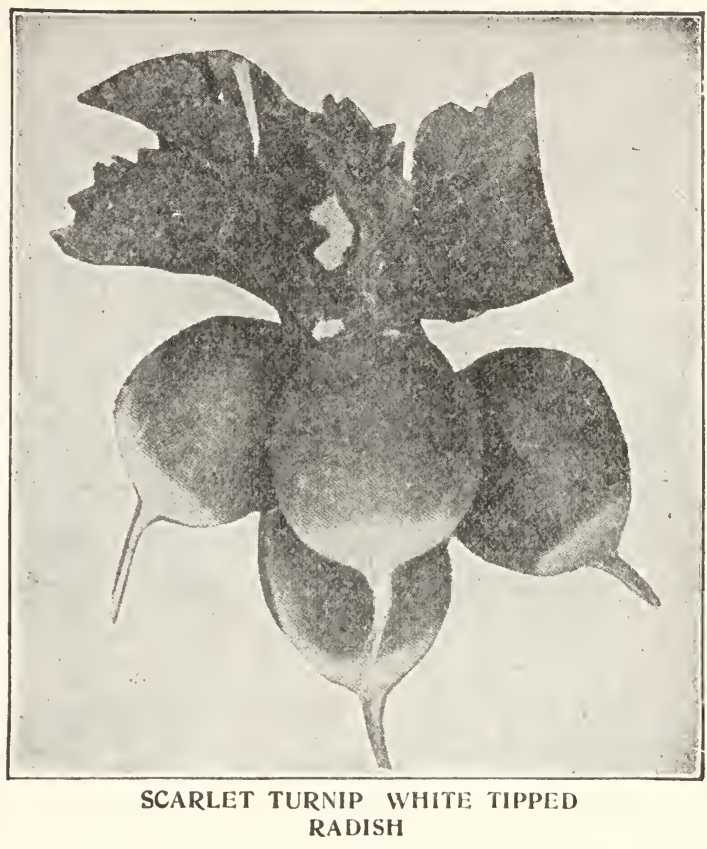

Pkt. 10c, oz. 15c, 1/4 lb. 30c, 1 lb. 90c.

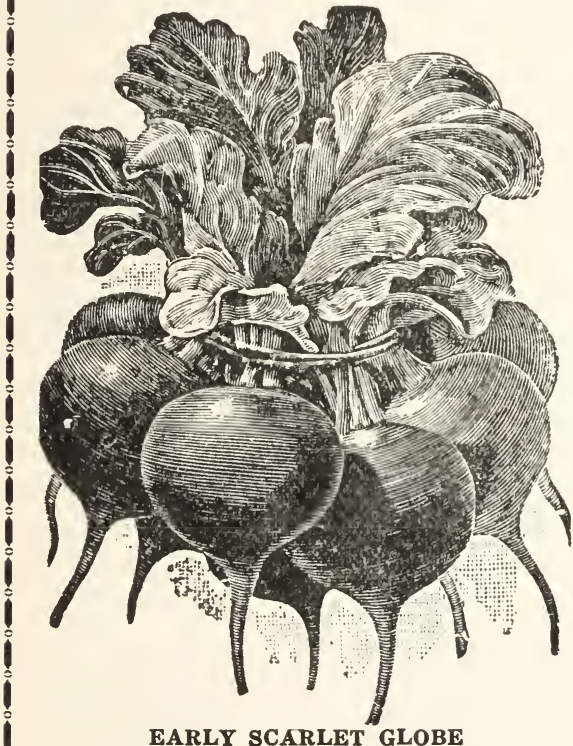

Early Scarlet Globe. (20 days.) This radish is a great favorite with market gardeners on account of its size and attractive appearance. Of beautiful color and one of the sweetest and tenderest on our whole list. Pkt. $10 \mathrm{c}, 1 / 4 \mathrm{lb} .25 \mathrm{c}, 1 \mathrm{lb}$. $80 \mathrm{c}$.

Scarlet Turnip, White Tipped. (22 days.) One of the most handsome of the turnip radishes and a great favorite in many large markets for early planting out-doors. Pkt. 10c, $1 / 4$ lb. 25c, $1 \mathrm{lb} .80 \mathrm{c}$.

Early Scarlet Turnip. (25 days.) A round, red turnip-shaped radish with a small top and of very quick growth. A very early variety, deserving general cultivation on account of its rich color and crisp, tender flesh. Very desirable for early out door planting as well as forcing. Pkt. 10c, 1/4 lb. 25c, 1 lb. $80 \mathrm{c}$.

Crimson Giant. (28 days.) A variety extraordinary in that while growing to unusually large size, is always tender, crisp and nild flavor. Root turnipshaped; color, beautiful crimson-carmine; fine crisp and tender. While very desirable as second forcing variety, we especially recommend for outdoor planting. Pkt. 10c, $1 / 4 \mathrm{lb}$. 25c, $1 \mathrm{lb}$. 80c.

Early White Box. (30 days.) A small, beautiful pure white sort of exceedingly quick growth, forming handsome, round white roots, of pearly white color. Has a small top and is excellent for family use as well as market. Pkt. 10c, $1 / 4$ lb. 25c, $1 \mathrm{lb} .80 \mathrm{c}$.

Early White Turnip. (25 days.) A very handsome and popular early turnip-shaped white variety. Of quick growth; color pure white; fine for forcing or open. Pkt. 10c, 1/4 lb. 25c, $1 \mathrm{lb}$. $80 \mathrm{c}$.

IF INTERESTED IN FRUIT GROWING, WRITE FOR PRICE LIST ON ALL KINDS OF SPRAY MATERIAL 


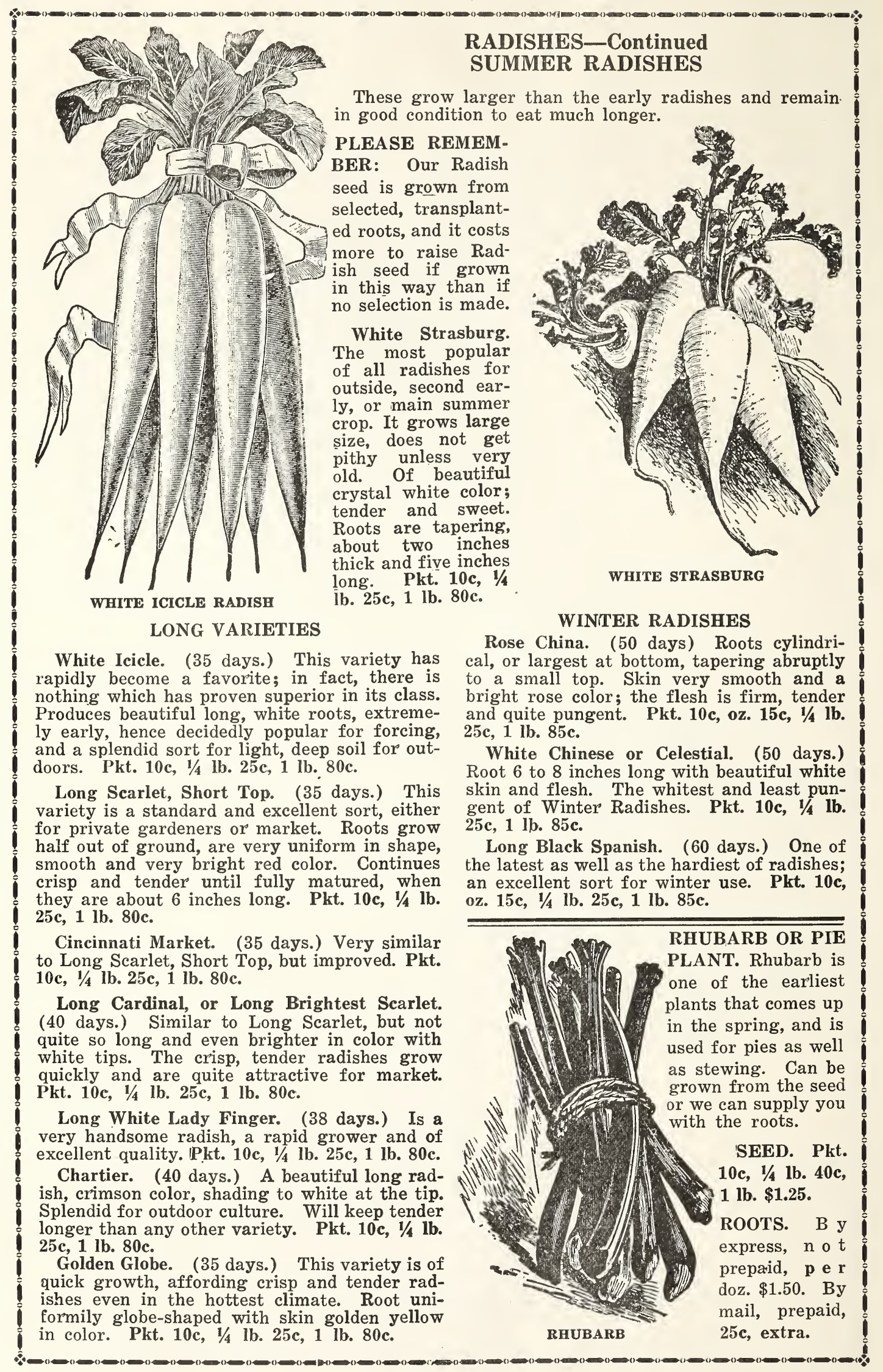


CULTURE-The squash is a tender annual. and should not be planted until all danger from frost is past. and the ground is warm, settled and dry; as aside from the tender nature of the plant. the seed is liable to rot in damp, cold weather. Flant in hills 5 to 6 feet for the bush varieties, such as White Bush Scallop, Yellow Summer Crookneck, etc., and in hills 6 to 8 feet apart for running varieties such as the Hubbards and other winter sorts; hills should be thoroughly manured. Slightly elevate hills and place 7 or 8 seeds in each. so as to have plenty for the bugs, finally leaving but 3 plants. Press seed down firmly before covering; cover early planted ones 1 inch and late ones 1 1-2 inches.

Prices Include Postage

Early White Scallop Bush, or Patty Pan Cymbling. (50 days.) For many years this has been extensively grown in the South for shipment to Northern and nearby markets, also for home use. It is early, of light cream color, very prolific, grows to nice size, and is an excellent shipper. Pkt. 10c, oz. 15c, 1/4 lb. 35c, 1 lb. $\$ 1.10$.

Yellow Summer Crookneck. (50 days.) One of the best of the summer squashes. It is of dwarf, bushy habit and very productive. The skin is yellow, flesh has greenish yellow color, is dry and most agreeable flavor. This is, in fact, the most highly esteemed of all summer varieties. Pkt. 10 c, oz. 15 c, $1 / 4$ lb. 35c, 1 lb. $\$ 1.10$.

Straightneck, Giant Summer. A selection from the Crookneck squash but with a straight rather than a crooked neck, and thus being more easily packed for shipment. Fruits intensely warted, 18 to 20 inches long, deep orange in color with a thick, meaty neck. Pkt. 10c, oz. 15c, 1/4 lb. 50c,

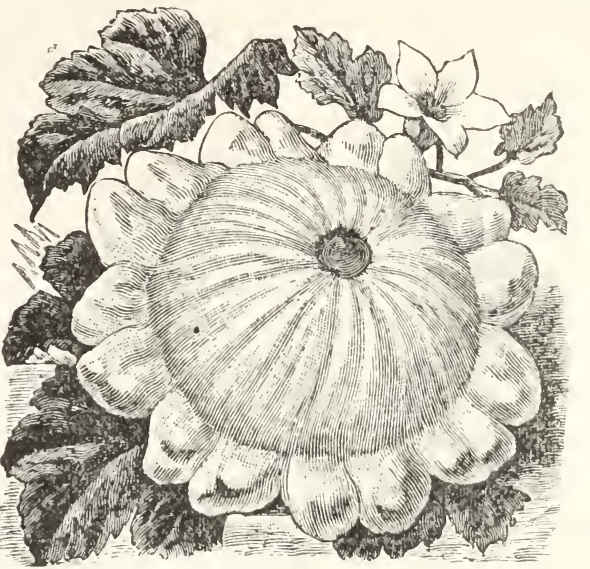

EARLY WHITE BUSH 1 lb. $\$ 1.50$.

Hubbard. (95 days.) A splendid keeping squash with orange-colored flesh, very dry, and of richest flavor. Pkt. 10c, oz. 15c, 1/4 lb. 40c, lb. $\$ 1.25$.

\section{S P I N A C H}

One ounce sows 100 feet of drill; $10 \mathrm{lbs}$. per acre in drill; 15 to $20 \mathrm{lbs}$. broadcast; 1/2 pound is sufficient for a medium garden. Sow in February, March or April. For fall and early spring, sow in September or October.

CULTURE-Sow in drills 1 inch deep, 18 inches to 2 feet between the rows or it can be sown broadcast like Kale. Requires but little or no cultivation.

Nobel, Giant Leaved. By far the best of the so-called smooth leaved sorts. It produces a large mass of rather smooth, very thick, rounded leaves, of enormous size, and although it is a very quick grower, it stands very long before bolting. Pkt. 10c, 1/4 lb. 15c, 1 lb. 40c, 5 lbs. $\$ 1.50,100$ lbs. $\$ 25.00$.

King of Denmark. This spinach stands longer before seeding than any other sort; grows vigorously and rapidly, forming compact rosettes of broad, thick, slightly crumpled, dark green leaves. Pkt. 10c, 1/4 lb. 15c, $1 \mathrm{lb}$. 35c.

Savoy or Bloomsdale. Very early and hardy, with leaves curled and wrinkled like a Savoy Cabbage. The best for fall sowing. Pkt. 10c, 1/4 lb. 15c, 1 lb. 35c, 10 lbs. @ 22c lb., 50 lbs. @20c lb., 100 lbs.@18c lb.

Round Thick Leaved. The best variety for spring seeding; makes thick, dark green, crumpled leaves of finest quality. Very slow in running to seed. Pkt. 10c, 1/4 lb. 15c, 1 lb. 35c, 10 lbs.@22c,50 lbs.@20c,100 lbs.@18c.

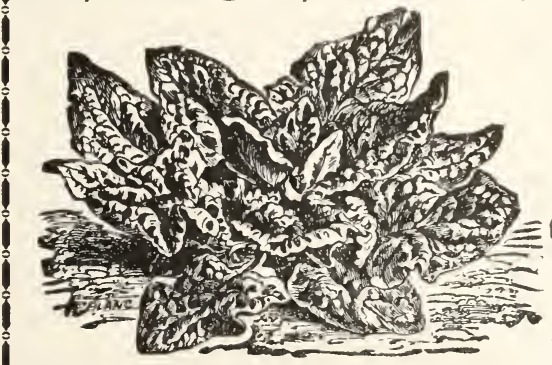

SAVOY OR BLOOMSDALE

Long Standing. Fine for both fall and spring sowing. Leaves thick and fleshy; stands long without running to seed. Pkt.10c,1 lb.35c,10 lbs.@22c,50 lbs.@20c, 100 lbs. $18 c$.

New Zealand Spinach. Entirely different from true Spinach in type. An all summer variety and it thrives during the hot weather in any soil rick or poor. The tender shoots are of good quality and may be cut through the summer. Plant 3 or 4 seed to the hill. Pkt. 10c, $1 / 4$ lb. $30 c$, lb. $\$ 1.00$.

New Japanese Mustard Spinach. This splendid Greens has a delicious flavor of Spinach, Mustard and Turnip Greens combined. See page (1) for full description. Oz. 10 c, $1 / 4$ lb. 25 c, lb. 75 c, 5 lbs. $\$ 3.00$.

\section{SALSIFY OR OYSTER PLANT}

CULTURE-Sow in March or April in rich. light soll: rows 18 inches apart and thin to 4 to 6 inches in rows. Cultivate often. One ounce sows 100 feet, 5 lbs. per acre.

There is no vegetable more rich and delicious than the Oyster Plant or Salsify. Splendid for winter use and should be extensively grown.

Mammoth Sandwich Island. (90 days.) A great improvement over the old sort, growing double the size. Quality excellent. Pkt. 10c, oz. 20c, 1/4 lb. 60c, 1 lb. \$2.00. 


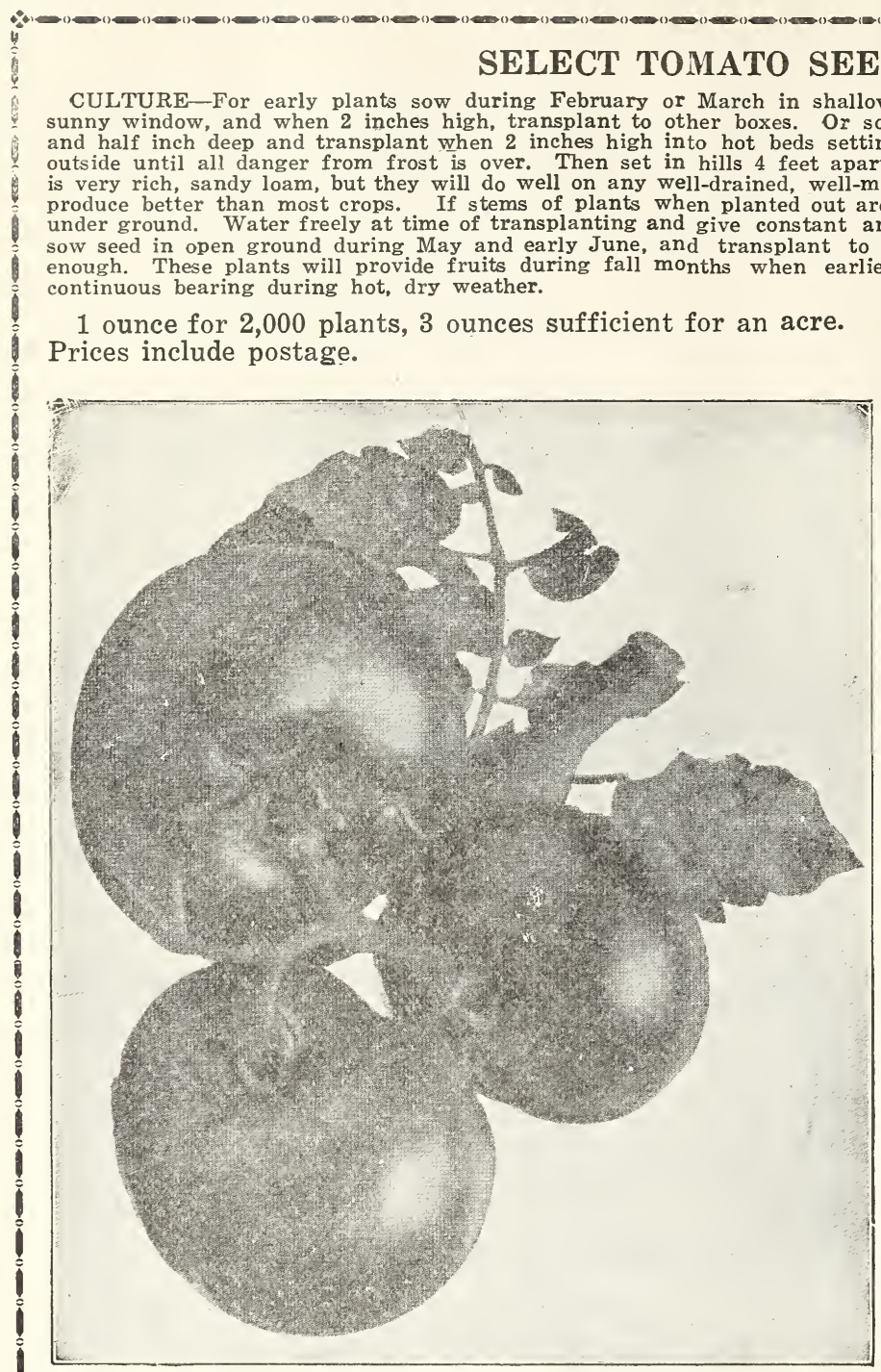

\section{SELECT TOMATO SEED}

作 outside 作 produce better than most crops. If stems of plants when planted out are very long they should be partly buried under ground. Water freely at time of transplanting and give constant and thorough cultivation. For late use, continuous bearing during hot, dry weather.

1 ounce for 2,000 plants, 3 ounces sufficient for an acre. Prices include postage.

\section{EXTRA EARLY EARLIANA}

Extra Early Earliana. (Red). (80 days.) A new strain of the well-known Earliana Tomato grown in Northern New York, it being earlier and more smooth than the old Earliana. If you are looking for a good extra early tomato, you can't get anything better than this variety. Pkt. 10c, oz. 40c, $1 / 4$ lb. $\$ 1.50,1 / 2$ lb. $\$ 2.50,1$ lb. $\$ 4.50$.

Chalk's Early Jewel. (95 days). The largest, smoothest, finest flavored, early tomato in cultivation; it is a heavy cropper with fruit of large size. Pkt. 10c, oz. 40c, 1/4 lb. $\$ 1.25,1$ lb. $\$ 4.00$.

New Stone Tomato. (115 days.) This is the most popular main crop variety in cultivation. This variety has obtained immense popularity with market gardeners, growers, canners and home growers everywhere. Its color is a desirable red. Its shape is perfectly smooth and thicker from stem to blossom end than most varieties. Pkt. 10c, oz. 25c, 1/4 lb. $75 \mathrm{c}, 1$ lb. $\$ 2.50$.
Bonny Best. (90 days). This new variety is somewhat earlier than Chalk's Early Jewel. A vigorous grower, very prolific, with larger foliage than most tomatoes, which protects fruit from the hot sun. When ripening, each set ripens nearly all at once, and evenly, all over up to stem. It is a good, early, red skin variety. Pkt. 10c, oz. 40c, $1 / 4$ lb. $\$ 1.25,1$ lb. $\$ 4.00$.

Dwarf Champion. (100 days). A purplish red early variety which is very dwarf growing, and the vines so stiff and upright that they are seif-supporting, even when laden with fruit. The branches are short, making a bushy plant growing about 2 feet high. Pkt. 10c, oz. 40c, $1 / 4$ lb. $\$ 1.25,1$ lb. $\$ 4.00$.

Extra Select Beauty.

(110 days). A decided favorite for either home market, or shipping purposes. The color is glossycrimson, with a tinge of purple. It grows in clusters of 4 to 6 large fruits, retaining its large size late in the season. Pkt. 10c, oz. 40 c, $1 / 4$ lb. $\$ 1.25$, lb. $\$ 4.00$.

Ponderosa Tomato. (120 days.) The finest tomato grown. Fruit ripens quite early and keeps on coming until very late; of immense size, solid, almost seedless and of delicious flavor. One of the best tomatoes for home use. Pkt. 10c, oz. 50c, $1 / 4$ lb. $\$ 1.75,1$ lb. $\$ 5.00$.

Yellow Ponderosa. (115 days.) Best of the large yellow sorts, resembling the Ponderosa in growth and shape, but a bright lemon color. Ripens evenly and is desirable for private use, forming a pretty contrast with the red sorts. Pkt. 10c, oz. 75c, 1/4 lb. $\$ 2.50,1$ lb. $\$ 8.00$.

Gulf State Market. (110 days.) An excellent shipping tomato, fruits medium to large, round or globe shape and are smooth and free from cracks, color deep purplish pink. The skin is firm and the flesh solid. One of the best purplish pink tomatoes. Pkt. 10c, oz. 40c, $1 / 4 \mathrm{lb}$. $\$ 1.25,1 \mathrm{lb}$. $\$ 4.00$.

June Pink. (90 days). One of the very earliest and most productive and best pinkfruited varieties in cultivation. The plants are of compact growth, produce more fruits for earliest picking and continues to bear in good quantities throughout the season. We especially recommend it for light, loamy, quick soils for earliest crops. The fruits are smooth, good size and quality. Pkt. 10c, oz. 40c, 1/4 lb. $\$ 1.25,1$ lb. $\$ 4.00$. 


\section{TOMATOES-Continued}

Wilt Resistant Tomatoes. Tomato wilt is a disease that causes the plant to gradually die about the time the first fruit is half grown; this disease is easily recognized by l examining a cross section of a stem, as a plant with wilt has a brown to black ring I surrounding the pith. If you have been disappointed in growing tomatoes because of 1 this disease you will be interested in these hardy Wilt Resistant varieties.

Norton "Wilt Resistant." (115 days). So serious has become the loss of tomato crops from the disease known as "Tomato Wilt," that a few years ago the U. S. Department of Agriculture started the breeding of a number of Wilt Resistant varieties. Of these the Norton is the most popular all-purpose variety. Color and shape similar to Stone. Pkt. 10c, oz. 40c. 1/4 lb. $\$ 1.25,1$ lb. $\$ 4.00$.

Marglobe. Wilt Resistant. (100 days.) This splendid new Tomato introduced by he U. S. Department of Agriculture through the efforts of Dr. Fred J. Pritchard of the Bureau of Plant Industry. Fine in appearance very productive, shape deep globe and very fine table quality; color a most beautiful scarlet, ripening well up to the stem. This tomato is truly very much in advance of the ordinary sorts, a truly remarkable commercial variety. Be sure to try this wonderful Tomato. Pkt. 10c, oz. 50c, 1/4 lb. $\$ 1.50,1 \mathrm{lb}$. $\$ 4.75$.

Louisiana Pink. Wilt Resistant. (110 days.) This variety has been grown and selected for ten years by the Louisiana Experiment Station, Baton Rouge, La. A smooth flesh, medium size, Pink Tomato with a small seed cavity and $\mathrm{f} \in \mathrm{w}$ seeds. The skin is medium in thickness. An unusually heavy producer. Pkt. 10c, oz. 50c, $1 / 4 \mathrm{lb}$.

$\$ 1.50,1$ lb. $\$ 4.75$.

Break O'Day, Wilt Resistant. (85 days). The newest development by Dr. Fred J. Pritchard of the U. S. Department of Agriculture. Was developed from Marglobe and - Marvana. This new Red Tomato should have a great future as there has long been a need for an extra early Wilt Resistant Tomato of good shipping qualities. Pkt. $25 \mathrm{c}, \mathrm{oz} . \$ 2.00$.

\section{H E R B S}

Packets of Either Varieties, 10c each, postpaid

Anise. Well known; has an agreeable aromatic odor and taste.

Basil. (Sweet). Used for flavoring soups and sauces.

Dill. The seeds are aromatic and are used in pickles.

Fennel.

Fennel. Leaves are larjely used.
Trucker's Favorite. (110 days.) The finest large-fruited purple tomato. Regular in form and size; thick meated and very solid. This is one of the largest smooth tomatoes grown. Pkt. 10c, oz. 40c, 1/4 lb. $\$ 1.25,1$ lb. $\$ 4.00$.

Matchless.

(115 days.)

The color is a rich red. The skin is so tough that it makes a splendid keeper and shipper, and is less liable to crack in wet weather than any other large tomato. Unsurpassed for market or table. Strong grower and very productive, bearing with undiminished vigor until frost. The fruit is free from core and the seed spaces comparatively small. Pkt. 10c, oz. 40c, $1 / 4$ lb. $\$ 1.25$, 1 lb. $\$ 4.00$.

\section{SMALL SORTS FOR PRESERVES AND PICKLES}

Yellow Pear Shaped. A popular sort for preserving and pickling. Probably the best sort for marketing purposes. Very prolific. Pkt. 10c, oz. 50c, $1 / 4$ lb. $\$ 1.50$.

Yellow Plum. Not quite so large in size as Yellow Pear, producing oblong, plum-shaped fruits, ripening evenly and most desirable for preserving. Pkt. $10 \mathrm{c}$, oz. 50c, $1 / 4$ lb. $\$ 1.50$.

Our Tomato Seed are taken from selected fruits and are superior in every way.

Marjoram. (Sweet). The tender tops are used green or dry for seasoning or flavoring.

Sage. Broad leaved English.

Summer Savory. Used extensively for dressing and soups.

Thyme. Used both green and dry for soups. 


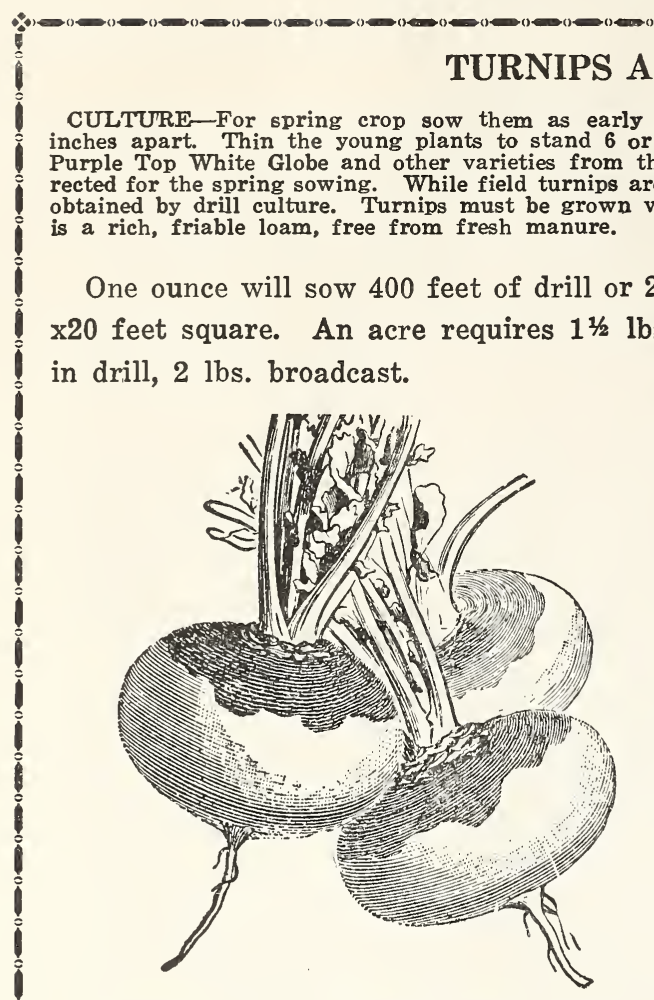

PURPLE TOP FLAT STRAP-LEAF TURNIP

\section{PRICES INCLUDE POSTAGE}

Purple Top Flat Strap Leaf. (60 days). The demand for this popular variety is always heavy. We take special care to secure extra selected seed from the most carefully grown stock. Has a bright purple top, white underneath. Pkt. 10c, 1/4 lb. 20c, 1 lb. 60 c, 5 lbs. $\$ 2.50$.

Purple Top White Globe. (70 days.) One of the handsomest and most profitable turnips, unsurpassed for either home or market use. Is a large, rapid-growing sort with globe-shaped roots, purple at top and white underneath. Pkt. 10c, 1/4 lb. 20c, 1 lb. 60c, 5 lbs. $\$ 2.50$.

Japanese Louse Resistant. Excellent variety for both early and late plantings, tops very large and upright, tender and juicy when cooked as greens. Roots solid white, between flat and globe in shape. Oz. 10c, $1 / 4$ lb. 25c, 1 lb. 75c, 5 lbs. $\$ 3.00$. See page one for more complete description.

Rutabaga-American Yellow Purple Top. (95 days.) The most satisfactory variety to grow for either family use or stock feeding. It is hardy, productive, sweet, solid and fine quality. Pkt. 10c, 1/4 lb. 20c, 1 lb. 60c, 5 lbs. $\$ 2.50$.

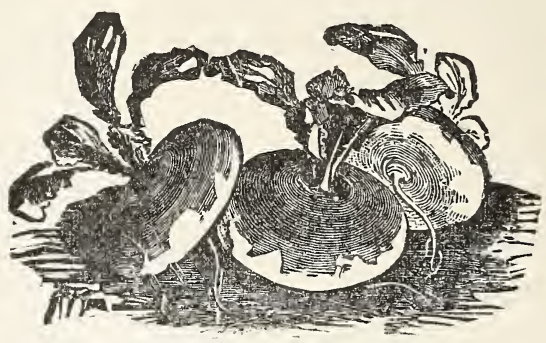

EARLY PURPLE TOP MILAN TURNIP

Early Purple Top Milan. (50 days).). The earliest. variety in cultivation. Ready for use a week earlier than any other. Shape flat and smooth. Medium size with bright purple top and few leaves. Pkt. 10c, 1/4 lb. 35c, 1 lb. $\$ 1.00$.

White Flat Dutch Strap Leaf. (55) days̄). The standard early turnip, flat in shape, smooth, and with clean, white skin. Flesh mild, juicy and of excellent flavor. Matures quickly and grows to medium size. Pkt. 10c, $1 / 4$ lb. 20c, 1 lb. 60c, 5 lbs. $\$ 2.50$.

Pomeranian White Globe. (75 days.) Produces immense, white, globe-shaped roots, which in rich ground, frequently attain a weight of 12 pounds. Pkt. 10c, 1/4 lb. 20c, 1 lb. 60c, 5 lbs. $\$ 2.50$.

White Egg. (60 days). This turnip forms a beautiful egg-shaped root, with a thin, white skin. IPkt. 10c, 1/4 lb. 20c, 1 lb. 60c, 5 lbs. \$2.50.

Seven Top. A variety of Turnip grown entirely for its tops, which are used as a salad. Produces no edible fruit. This is a very hardy sort, standing through the winter without any protection. Pkt. 10c, 1/4 lb. 20c, 1 lb. 50c, 5 lbs. $\$ 2.25$.

\section{TOBACCO SEED Prices Include Postage}

One ounce sows 150 square yards, sufficient to set 6 to 8 acres.

Improved One Sucker. A good medium width and long-leaf heavy tobacco. A true one-sucker. Good Italian grade. 1/4 oz. 25c, $1 / 2$ oz. 40 c, oz. 75 c, $1 / 4$ lb. $\$ 2.50$.

Madow. Broad leaf, medium early. We think one of the best varieties for all purpose; one of the best wild fire resistant tobaccos grown. $1 / 4$ oz. $25 \mathrm{c}, 1 / 2$ oz. $40 \mathrm{c}, 1$ oz. $75 \mathrm{c}, 1 / 4 \mathrm{lb}$. $\$ 2.50$.

Black Kelly. One of the best extra early tobaccos grown. Has a broad, short leaf, easy worked and a splendid all-purpose tobacco. 1/4 oz. 25 c, $1 / 2$ oz. 40 c, 1 oz, 75 c. $1 / 4$ lb. $\$ 2.50$.

Judy's Pride White Burley. Burley tobacco is becoming more popular each year, and this variety seems to be the best adapted to this section. $1 / 4$ oz. $25 \mathrm{c}, 1 / 2 \mathrm{oz}, 40 \mathrm{c}, 1 \mathrm{oz} .75 \mathrm{c}$.

White Burley, (Certified Root-Rot Resistant.) The best in Burley Tobacco. Grown from the latest improved strain, selected, developed and certified by the Kentucky Agricultural Experiment Sation. Price, Pkt. 10c, $1 / 4$ oz. 40 c, $1 / 2$ oz. 75 c, 1 oz. $\$ 1.25$.

Use Nitrate of Soda for Plant Forcing 


\section{SEED CORN-White}

Paducah Market. (70 days.) A. very early fair sized ears, well filled, recommended highly for roasting ears and planted largely for early maturing field corn. $10 \mathrm{lbs}$. $\$ 1,00$, bu. $\$ 3.00$.

Silver Mine...(90 to 100 days.) One of the very best yielding White Dent corns. Originated in Ford County, Illinois, and introduced in Iowa. Creamy white in color cylindrical shape, tapering only a little at the tip: 18 to 20 rows: length 9 inches circumference 7 1-4 inches: kernels rough and deep, a little space between rows. A fine shelling and high-yielding variety. $1 / 4$ bu. 75 c, bu. $\$ 2.50$.

Hickory King. (100 to 110 days). An old favorite sort, well known in this locality. Ears are rather small, but usually 2 or 8 on the stalk, and it is a good yielder. The cobs of this variety are small, a single grain of corn sometimes being large enough to eover a cross section of the cob. The grains are very large, flinty, and of the finest quality for milling or feeding. $1 / 4$ bu. 75 , bu. $\$ 2.50$.

Tennessee Red Cob. (120 days). An extra large field corn, the ears of this sort run from 9 to 12 inches long and have from 18 to 20 rows. It is a rather late maturing sort, but for bottom land and late crops this corn cannot be excelled. One of the best milling corns: stalks from 8 to 12 feet high and broad and short jointed. It makes one of the best ensilage corns. $1 / 4$ bu. $75 \mathrm{c}$, bu. $\$ 2.50$.

Boone County. (100 to 110 days). It is a very large, white corn, somewhat like Silver Mine, larger and later. Ear 10 to 11 inches long, cylindrical, 18 to 22 rows. Grain deep and rather rough. Well filled at both ends. Cobs always white and medium size. 1/ bu. $75 \mathrm{c}$, bu. $\$ 2,50$.

Neals Paymaster. (110 days). This has become the most popular of the Red Cob Dent Corns. The grain is softer and more dented than the other Red Cob Corns and has two ears to most every stalk. The yield of this Corn is very large. The ears are of sized cob. $1 / 4$ bu. $75 c, 1$ bu. $\$ 2.50$.

\section{SEED CORN-Yellow}

Reid's Yellow Dent (100 days). This is now the standard variety in many of the corn-growing sections of the Middle West Ears average 9 to 10 inches, tapering slightly toward tip, are about 6 inches in circumference, contain from 14 to 16 rows and are remarkably uniform. Kernels light yellow, deeply dented and well placed on a cob of medium size. $1 / 4$ bu. $75 \mathrm{c}$, bu. $\$ 2.50$.
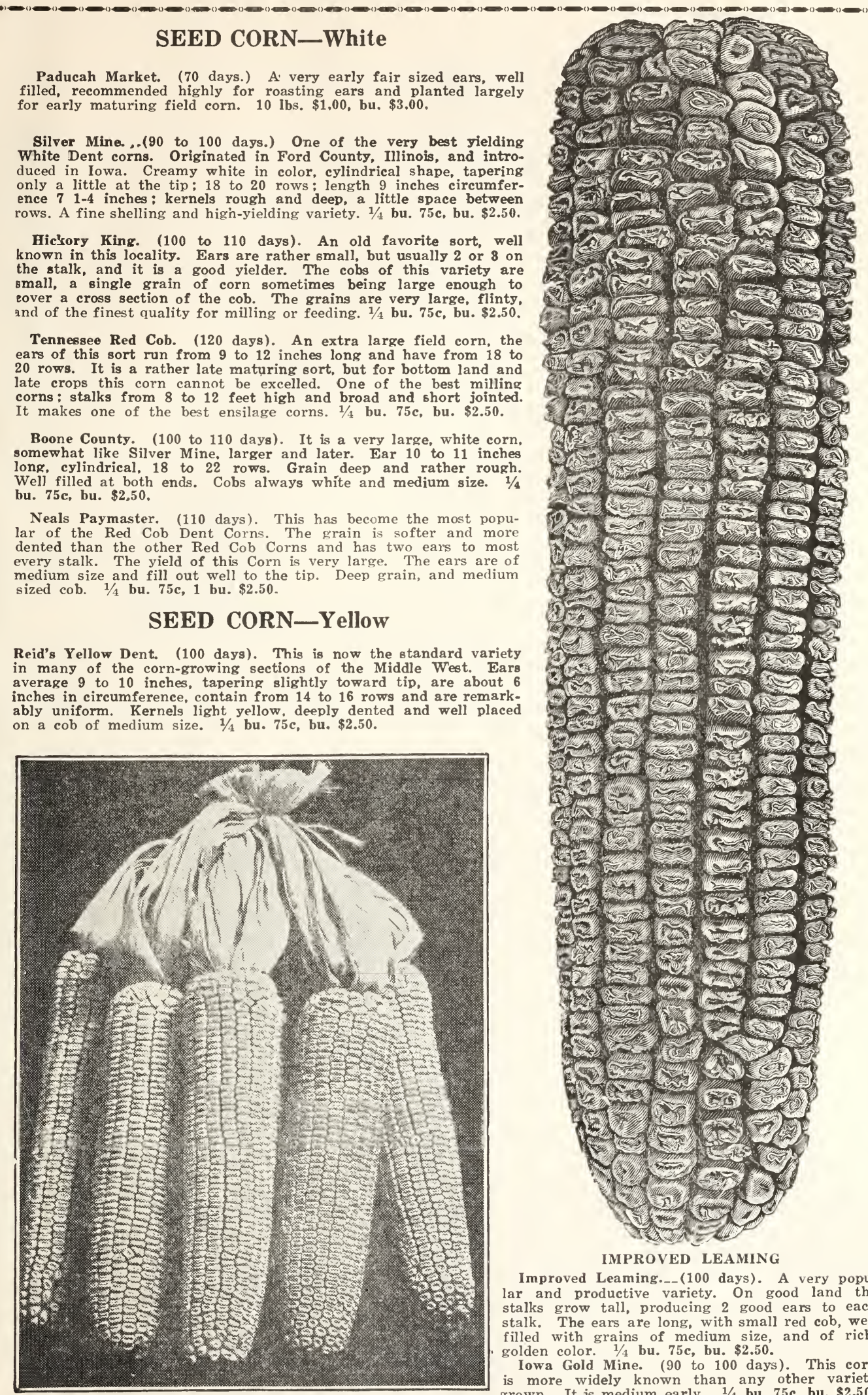

IMPROVED LEAMING

Improved Leaming.--(100 days). A very popular and productive variety. On good land the stalks grow tall, producing 2 good ears to each stalk. The ears a re long, with small red cob, well filled with grains of medium size, and of rich, golden color. $1 / 4$ bu. $75 \mathrm{c}$, bu. $\$ 2.50$

Iowa Gold Mine. (90 to 100 days $)$. This corn grown. It is medium early. $1 / 4$ bu. $75 \mathrm{c}$, bu. $\$ 2.50$. BOONE COUNTY WHITE DENT WRITE FOR PRICES ON ALL FIELD SEEDS 


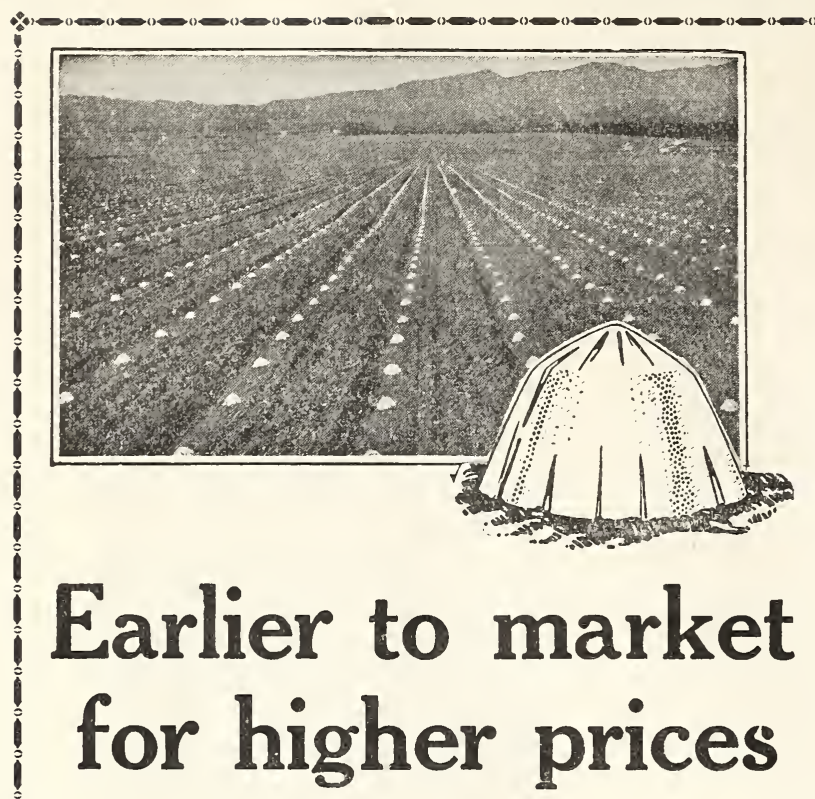

HOTKAPS are inexpensive to use. One man can "set" over 3000 of them per day.

Write us now about this moneymaking crop necessity, or simply order your season's supply now.

Prices: 1,000 lots, $\$ 11.50 ; 5,000$ lots, $\$ 11.00$ per $\mathrm{M} ; 10,000$ lots, $\$ 10.75$ per M; 250 Trial Package, including Garden Setter with Tamper, $\$ 4.00 ; 100$ Home Package, including Garden Setter with Tamper, $\$ 2.50$; Germaco Hotkap Steel Setter with Tamper, $\$ 2.50$; postage extra.

Weights: 1,000 package HOTKAPS, 26 lbs.; 250 package, 9 lbs.; 100 package, 5 lbs.; Steel Hotkap Setter, 3 lbs.

Germaco HOTKAPS-“individual hothouses for every. plant"-are made of waxed paper in the form of a cone which completely covers the plants-the only way to fully protect them from frost. HOTKAPS also protect against rain, wind, ground-crusting and insects-your assurance of faster-growing, hardier plants, with larger yields and greater profits, because you market earlier.

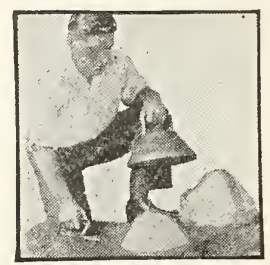

Germāco

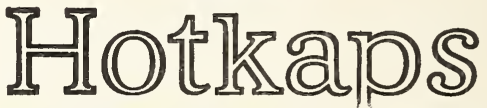

\section{MYTRS SELF. MYERS OILING For Shallow and Deep Wells}

Self-Oiling-Self-St arting-Self-Stopping

Complete Automatic Control of Air and Water

Style and Sizes for Any Installation Up to Ten Thousand Gallons of Water per Hour.

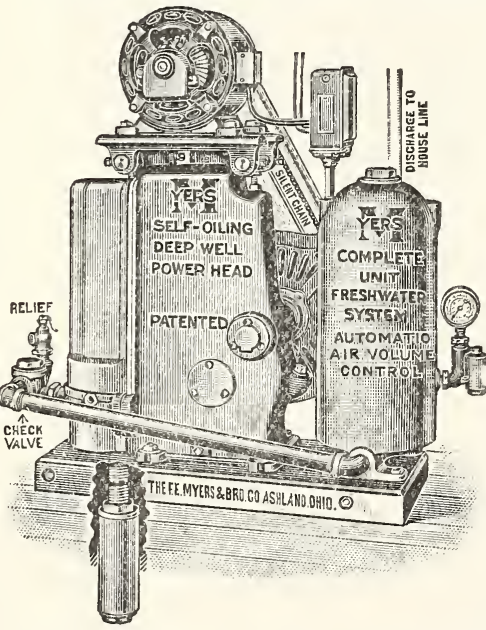

More than fifty years of experience is back of every Myers Water System. All are typical of Myers superior quality. Expert engineering design, pract i c a l improvements, careful workmanship, assure users the utmost in value.

You can now enjoy running water conven-

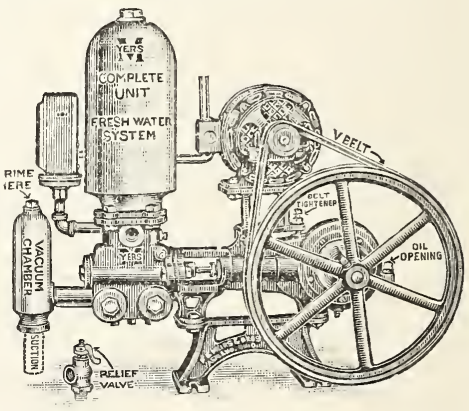
iences equal to those provided by city water service. House stables and yards-anywhere about the premises-water at the turn of a faucet automatically supplied means a saving of time and labor that quickly pays for a Myers Water System. The Meyers company builds water systems -hand, wind, engine or motor operation-for deep or shallow wells, in styles and sizes to meet your requirements, whether they be a few hundred gallons a day or thousands of gallons an hour.

Ask for Catalog and Prices on the Complete Myers Line of Water Systems. 
Lespedeza. (Japan Clover). This crop is exceedingly valuable to the farmer in building the fertility of his valuable to the farmer in building the fertility of his when this can be obtained through Lespedeza which is the when this can be obtained through Lespedeza which is the no legume so valuable and no legume so sure. You don't need Lime and you don't need fertilizer to grow Lespedeza. Especially is this true of Kobe and Korean Lespedeza. It has several advantages over Red Clover. First, it will grow well on soil that has not been limed. rirst, it in it has lasting qualities uncommon in Red Clover as it it has lasting qualities uncommon in Red Clover as it innoculation. It is remarkable drought resisting. Sevinnoculation. It is remarkable drought resisting. Seva cover crop or mulch crop in their apple orchards, especially the Korean and Kobe.

Korean Lespedeza. This new early mammoth variety Jf Lespedeza or Japan Clover not only is much earlier than the ordinary variety but yields almost twice as much hay and on the average of four times as much much

Kobe Lespedeza. A late variety of Mammoth Lespedeza (Japan Clover) much later than Korean. It stays green until nearly Christmas if the frost is not too severe, does not produce as much seed as Korean but probably twice as much seed as the Common Lespedeza. For pasture, best results can be obtained by mixing one-half Kobe and colf Korn one-half Korean. ct will have a tendency to hold the Korean up and you will have a very late pasture as well as an early one from the Korean. Write for prices.

\section{SEED OATS}

Recleaned and tested for Germination.

Burt or Ninety-Day Oats.

White Spring Oats.

Black, Mixed Spring Oats.
COW PEAS

THE GREAT SOIL IMPROVER

Makes poor land rich; makes good land more productive. Also makes splendid hay crop.

CULTURE-Sow in June or July at the rate of 1 to $1 \frac{1}{2}$ bushels per acre broadcast or in a wheat drill.

New Era. The peas are dull lead colored, not quite as large as the Whippoorwill, but the vine is somewhat longer. Earlier than the Whippoorwill, and produces more peas.

Red Ripper. Red seeded, a most desirable and productive variety.

Whippoorwill. A favorite early bunch-growing variety; has brown speckled seed, which are more easily gathered than from the vine-growing sorts. This variety is a favorite in the Middle West on account of its early maturity and habit of growth.

Clay Cow Peas. A favorite variety in the South. Grow similar to Black. Produce abundance of vine. Color of peas is light brown.

Mixed Cow Peas. A mixture of Clays, Whippoorwills, Blacks and some other sorts, which are offered at a lower price. Price fluctuates. Write for prices on all Cow Peas.

\section{EDIBLE COW PEAS}

Black Eyed Peas. Large black eyed peas make a profitable crop for picking before getting dry, and hulled and sold on the market, or the dry peas sold luring the winter. Lb. 15c.

Lady Peas. Very fine for table use. Very small.

Rice Peas. Round, medium size, white peas, Cook very quickly.

Brown Crowders. Very fine for table use; also make good hay crops. ASK FOR PRICES

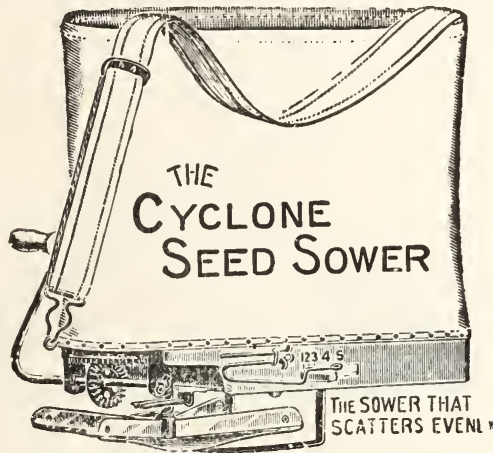

SORGHUM OR CANE

Texas Honey Dew. One of the best Sorghums ever used for making molasses. Makes a clear, fine syrup, rich amber color, containing much more saccharine matter than syrups from other cane. 1 lb. 10c.

Blue Ribbon. This is one of the best varieties of Sorghum for Syrup. Largely planted in this section and a favorite sort among our farmers. $1 \mathrm{lb} .10 \mathrm{c}$

Early Orange. For molases or fodder. It is a favorite in Southern States, as it produces a heavier crop. 1 lb. 10c.

Early Amber Sorghum. (For fodder only). Furnishes a large yield of most nutritious forage, which can be fed either green or cured. Will yield two or three cuttings a year, shooting out thicker each time it is cut.

\section{Wrte for prices \\ KAFFIR CORN}

White Kaffir. This grain makes most nutritious feed and can be used for both stock and poultry. $1 \mathrm{lb}$. $10 \mathrm{c}$.

Feterita. A new fodder plant of the Kaffir Corn type, but maturing from 15 to 20 days earlier than Kaffir Corn. Is also remarkable for its drought-resisting quality. 1 Ib. 10c.

We also have in stock, Red Kaffir Corn, Dwarf White Kaffir Corn, Milo Maize and Jerusalem Corn. Write for prices.

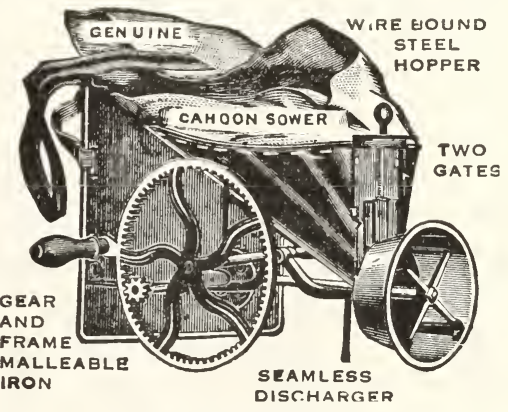

Lightning (Tin Horn Seeder), each $\$ 1.00$. BUCKWHEAT

CULTURE-A valuable crop for soil improving. production of grain, and largely used for sowing for bees. It is better not to sow before June, though July and August are better months in this latitude.

Japanese. One of the best sorts, with large grain, and produces much larger yields than the common buckwheat. Ask for price.

\section{BROOM CORN}

Improved Evergreen. The best variety in cultivation, on account of color and quality of brush; ripens very early, grows about 8 to 10 feet high; brush of good length, fine and straight, and always of green appearance when ripe. $1 \mathrm{lb}$. $10 \mathrm{c}$.

Oklahoma Dwarf. An extra early sort. Average height about 5 feet. Is also less trouble to harvest, while the yield is nearly the same as the tall variety.
$1 \mathrm{lb} .10 \mathrm{c}$.

Black Japanese. A new Broom Corn and one of the best; has fine straw, of good length. Try this new variety. $1 \mathrm{lb} .10 \mathrm{c}$.

Russian Sunflower. This is highly prized by poultry raisers and farmers as a cheap food for fowls. Best egg-producing food known. Oz. Bc, 1/4 lb. 10c,
1 lb. 20c.

Hairy or Sand Vetch. (Vicia Billosa). Recommended for all seeding at the rate of 15 to 30 pounds per acre with rye or winter oats. Yields enormously, and can be used either green or dry, similar to clover hay. 


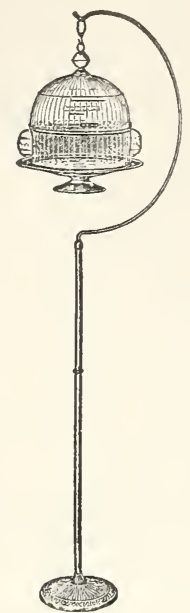

Stand Only

Red and black, each _-_._-_. $\$ 1.25$

Blue and gold, each

\section{2.}

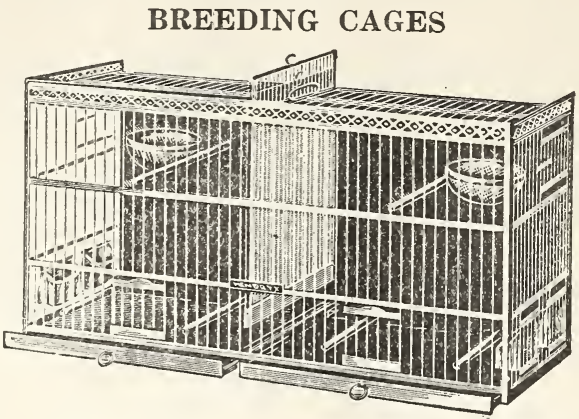

Size No. 1

$17 \frac{1}{4} \times 8 \frac{3}{4} \times 14$

each _..... $\$ 4.00$

Size No. 2

$22 \times 11 \times 16 \frac{1}{4}$ each ------- $\$ 5.50$

Parrot Cages, round 131/2 in. diameter

20 in. high_._-_._-_._-_ $\$ 6.00$

Parrot Cages, square, $16 \times 115 / 8 \times 24 \ldots-$ - 8.50

\section{CANARY BIRDS}

Imported Rollers, male

$\$ 7.50$

Imported Rollers, female_._._._._._. 2.50

Hartz Mountain, male

Hartz Mountain, female

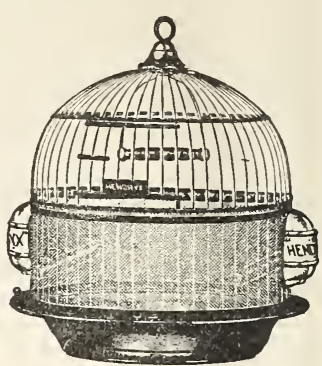

CAGES

Brass

Size 1__-_\$3.25 each Size 2 _...- 3.50 each Size 3.-.-- 4.00 each

Red with Black

Size 1__._. $\$ 2.00$ each Size $2 \ldots-2.25$ each

Size 3..... 2.50 each Blue and Gold

Size 1_._\$2.00 each Size $2 \ldots \ldots 2.25$ each Size 3 ....- 2.50 each

All prices F. O. B. Paducah-Birds by express only.
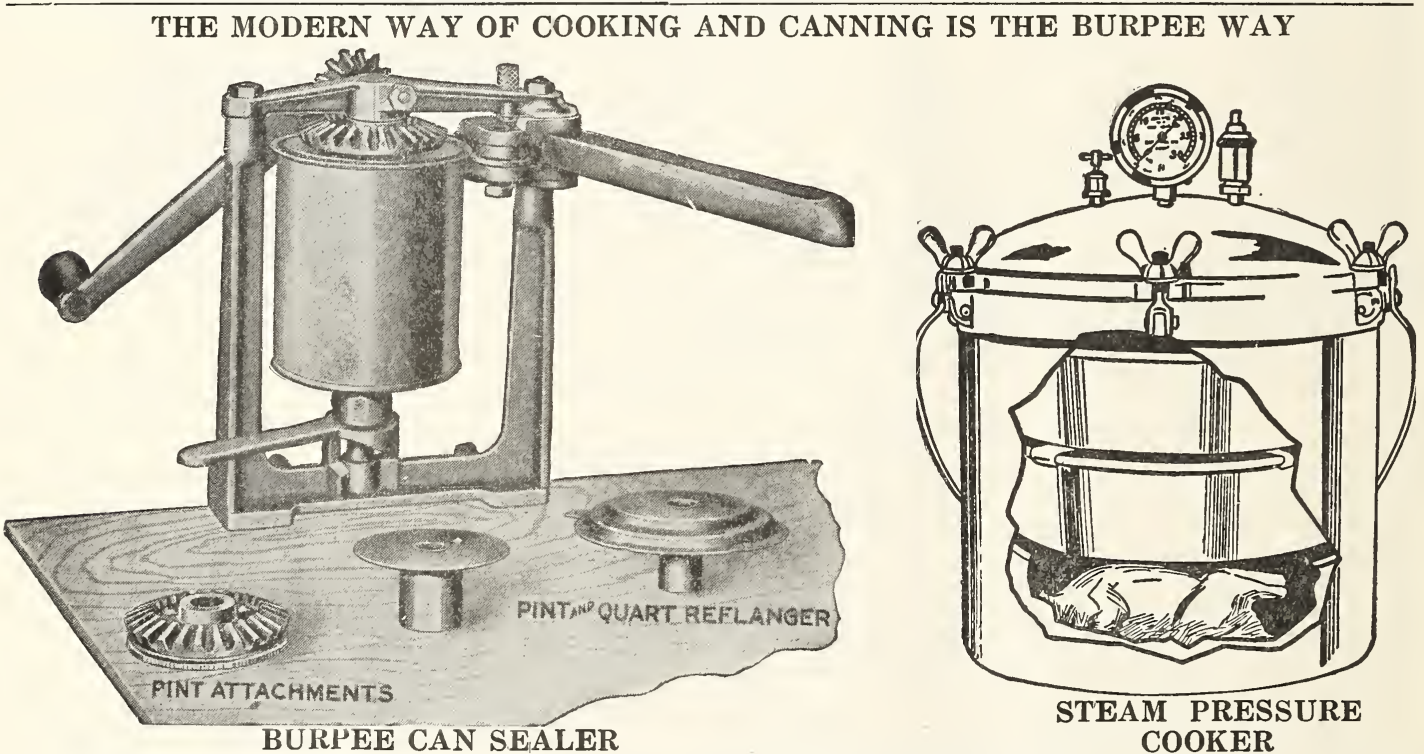

The Burpee Can Sealer is exceedingly simple and anyone, even a child, can quickly acquire the knowledge necessary to operate it successfully.

It is complete in itself. and all that is requi red is to attach it to a shelf or table with the strong double screw clamps with which it is provided and it is ready for action.

Likewise the machine is also for cutting the tops off cans, as well as reflanging cans that have been previously used. Special rolls are furnished for these operations. Write for prices on cans, sealer's and cookers.

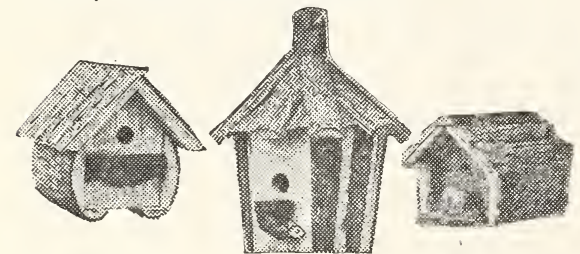

BIRD HOMES Blue Bird Wren or Woodpecker Houses, $\$ 1.75$ each or Assortment of three for $\$ 5.00$

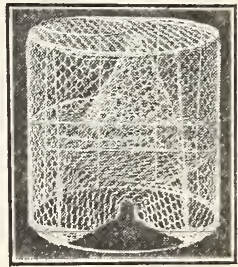

Sparrow

Traps

$\$ 5.00$

each 


\section{BIRD FOOD AND REMEDIES}

HALLERS Pkg.

Canary Bird Pie_._-_-_._-_-_-_-_-_15c

Bird Tonic, Bottle

Mocking Bird Food_._.

Cod Liver Oil Nesting Food

Parrot Food _..-_-

Health Food

Scaly Leg Oil

Sure Cure Parrot Tonic, Bottle_-_-_-_-25c

Color Food -..-_..-_.

Cage Wash, Bottle

Natural Fish Food... MISCELLANEOUS SPRATTS

Song Restorer

Cod Liver Oil Nestling Food_--_--_---_20c

Egg Flake and Fruit_._-

i Bird Manna

Bird Bitters, Bottle_._._.

French's Bird Seed._.

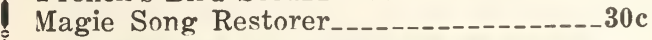

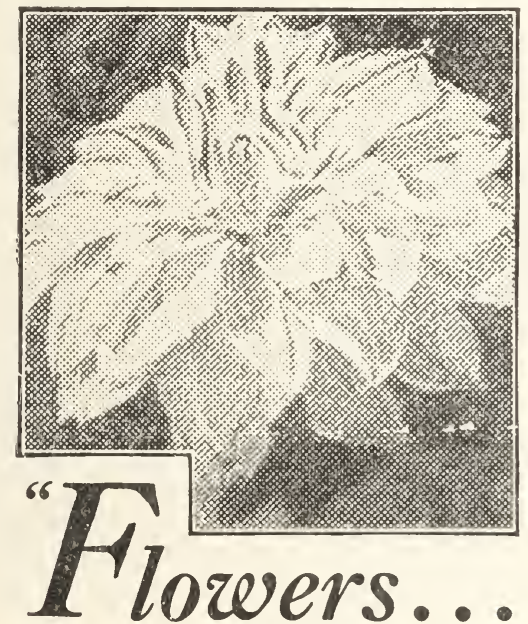

\section{larger, more blossoms}

"I am very pleased with Vigoro's results on all my plants," writes E. A. Heins, 112 Clarewill Ave., Montclair, N. J. "They were larger, had more blossorns than in previous years."

Easy, success like this, with Vigoro! Better lawns, vegetables, shrubs, trees, too. Complete, balanced, Vigoro supplies all elements of plant food for sturdy growth, full development. Clean, odorless! Costs only $10 \mathrm{c}$ to $20 \mathrm{c}$ per 100 sq. ft. Sold where you buy lawn, garden supplies. Order today!

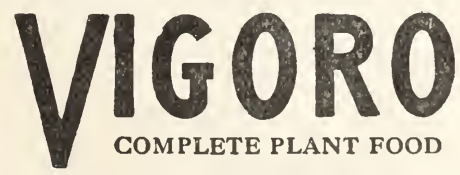

A SWIFT \& COMPANY product Price: 5 lbs. 50c, 25 lbs. $\$ 1.75,50$ lbs. $\$ 3.00,100$ lbs. $\$ 5.00$. F. O. B. Paducah.
Red Diamond Bird Seed

Cuttle Bone-5c each, 3 for

Bird Nests, each__-_-__-_-_-_-_-_-_-_-15c

Hendryx Feedcup, Glass, each._.....

Hendryx Feedcup, Opal__._-_-_-_-_-_-_15c

Hendryx Opal Bath Tubs, each

Straight Canary Seed, Bulk, lb._-_-_-_-_15c

Straight Canary Seed, 10 lbs. at_---_--121/2c

German Sweet Rape, 1 lb....-..-_-_-_-15c German Sweet Rape, 10 lbs. at_-_-_-_121/2 c Hemp Seed, 1 lb. Hemp Seed, 10 lbs., at._._. Mixed Bird Seed, Bulk, lb...-. Mixed Bird Seed, 10 lbs. at _-_-_-_-_--121/2c Sunflower Seed for Parrots, lb._._...-_-_15c Sunflower Seed for Parrots, $10 \mathrm{lbs}$. at_- 121/2 c Mixed Mexican Cardinal (Red Bird) Food, lb. Mixed Mexican Cardinal (Red Bird)

Food, 10 lbs. at Love Bird Seed, 15c lb., $10 \mathrm{lbs}$. at.-_- 121/2 Bellows Lice Powder._._._. Bird Gravel _.

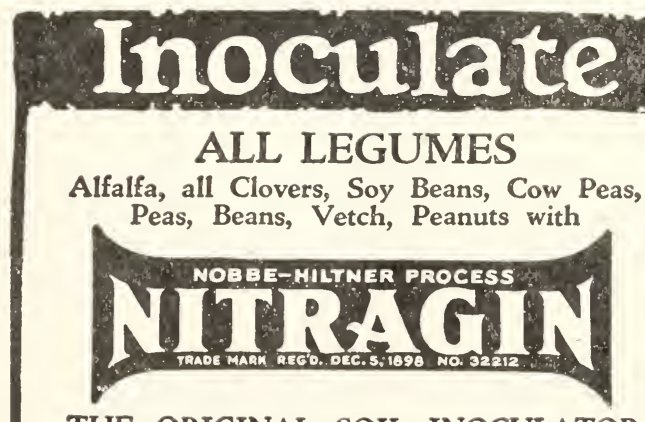

THE ORIGINAL SOIL INOCULATOR with the Date and Germ Count on every can For profitable results, Agricultural Colleges advise inoculation for all legume seed, because it pays well in producing larger quality yields. Fresh, high count NITRAGIN, containing billions of nitrogen-gathering germs build up the soil. Costs less than others - is cheapest crop insurance. Insist on NITRAGIN.

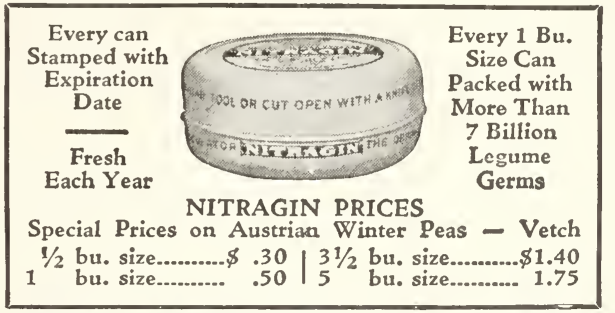

Alfalfa, All Clovers, - Peas, Beans $\frac{\text { Size }}{\mathrm{S} / 4 \mathrm{bu} .} \frac{\text { Inoculates }}{15 \mathrm{lbs} \text {. seed }} \frac{\text { Price }}{\$ .40} \frac{\text { Size }}{1 \mathrm{bu} .} \frac{\text { Inoculates }}{60 \mathrm{lbs} \text {. seed }} \frac{\text { Price }}{\$ 1.00}$

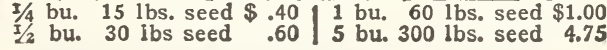

Special Prices on Soy Beans and Cow Peas (Note sizes carefully - not packed in smaller sizes) 1 bu. 60 lbs. seed $\$ .40 \mid 5$ bu. 300 lbs. seed $\$ 1.50$

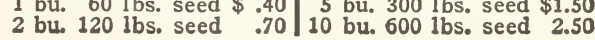
GARDEN NITRAGIN

Inoculates from 1 ounce to $8 \mathrm{lbs}$. seed. Price, $\$ .25$ IMPORTANT: When ordering NITRAGIN, always be sure to state kind of legume seed you wish to inoculate.

Nitragin Has Served the American Farmer Since 1898 


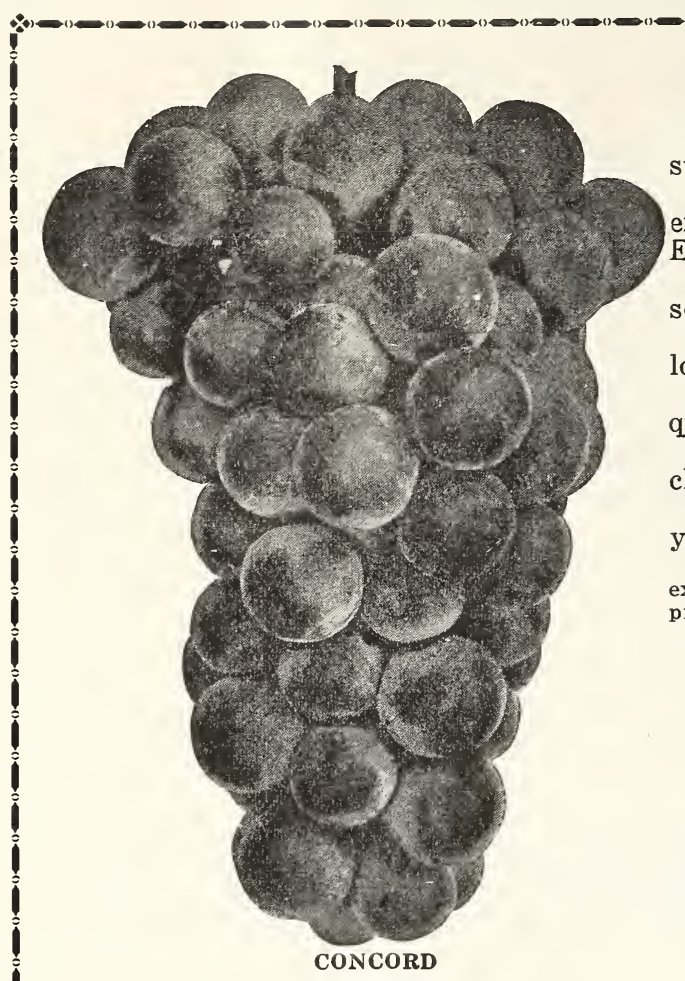

\section{PEACHES}

Mayflower, very early, cling stone.

Red Bird Cling, high color, good quality, cling stone.

Belle of Georgia, large, skin white, red cheek, excellent flavor, free stone. Ripens just ahead of Elberta.

Champion, white free stone, good quality, mid season.

Elberta, most popular peach in cultivation, yellow free stone.

J. H. Hale, very large size, beautiful color, fine quality yellow free stone.

Heath Cling, large white, fine canning peach, cling stone.

Krummel, ripens 4 weeks after Elberta, large yellow free stone.

All above peaches 2 to 3 feet. June Buds. Postage or express prepaid. 20c each; 20 or more 15c each. Write for prices on large quantities.

\section{GRAPES}

Concord, purplish black, 2 yr., 25c each. Niagara, white, 2 yr., $25 \mathrm{c}$ each.

Moore's Early, purplish black, 2 yr., 25c ea.

Lucille, red, 2 yr., $25 \mathrm{c}$.

\section{APPLES}

\section{Red June}

Transparent

Paducah

Grimes Golden

2 years 4 to 5 feet. Single Tree, $50 \mathrm{c}$; Lots of 5 or more 40c each. Postage or express prepaid.

\section{PLUM}

Abundance (Early) Purplish red, Japanese Plum, each $75 \mathrm{c}$.

Burbank, (mid season), dark red, Japanese Plum, each $75 \mathrm{c}$.

Wild Goose, (early), bright red, native, each 75 c.

Damson, (late) dull purplish black color, each $\mathbf{7 5} \mathrm{c}$ Postage or express prepaid

\section{YOPP'S CHIEF BRAND LAWN GRASS}

In this mixture we use only the best tested grass seed. For the most beautiful velvety lawn the year 'round, you will find nothing to compare with this mixture. $1 \mathbf{l b}$. 40c. 5 lbs. for \$1.75, Postage extra,

\section{YOPP'S PERMANENT LAWN OR PASTURE GRASS}

Especially prepared for use on large lawns, where lawn and grazing are desired. 1 lb. $40 \mathrm{c}, 5 \mathrm{lbs}, \$ 1.75 .100 \mathrm{lbs}$. $\$ 30.00$. See front cover for parcel post rates.

\section{KENTUCKY BLUE GRASS}

For lawn purposes we consider it the standard and superior to any ther sort. Will grow in most any soil, but more adapted to limestone soils. 1 lb. 50c, 3 lbs. but more adapted to limestone soils. 1 ib.
$\$ 1.25$. Write for prices on larger quantities.

Shade Lawn Grass. (Poa Trivialis.) Especially adapted for shady lawns, has a fine blade which makes a beautiful lawn. If you have shady spots in your lawn and have not been able to get a stand of grass you would not make a mistake trying this new grass. Price 60c 1

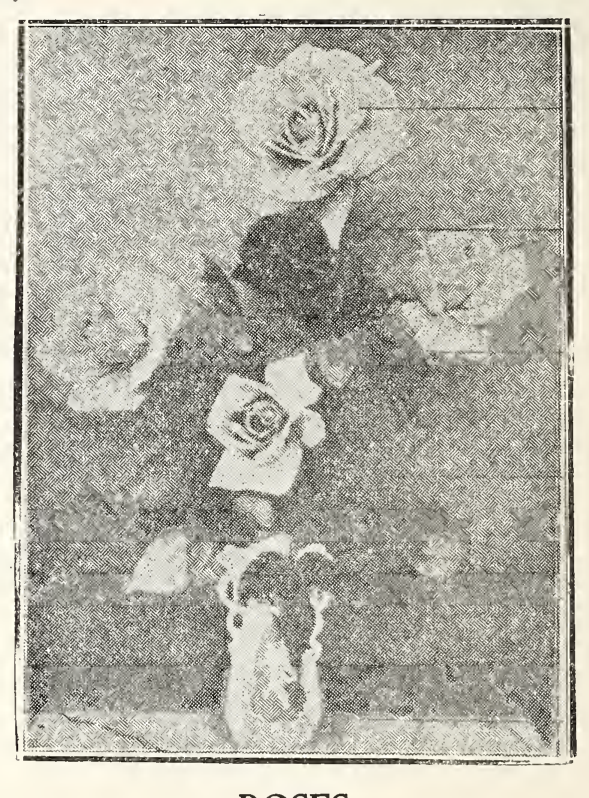

\section{ROSES}

Named Varieties-For Spring Delivery Only Price: all Roses listed 15c each, 10 for $\$ 1.25$. Postage charges paid.

RYdiance, TEA

Radiance, Pink
Radiance, Red

Radiance, Red
Kiserine Aug. Victoria, Cream

Lady Hillingdon, Yellow

Maman Cochet, Pink

Sunburst, Coppery Yellow

Bridesmaid, Pink

Bridesmaid, Pink
Helen Gould, Cherry Red

Helen Gould, Cherry Red
HARDY CLIMBING

Dr. Van Fleet, Pink

Emily Gray, Yellow

Christine Wright, Pink

Pauls Scarlet, Red

Silver Moon, Cream CLIMBING HYBRID TEA OR MONTHLY FLOWERING

K. A. Victoria, White Cream

Lady Ashtown, Pink

Sunburst, Coppery Yellow

\section{CHERRIES}

Montmorency, large, sour, color fruit beautiful glowing red, each $75 \mathrm{c}$.

Governor Wood, sweet, yellowish white tinted with crimson, each $75 \mathrm{c}$.

Postage or express prepaid 


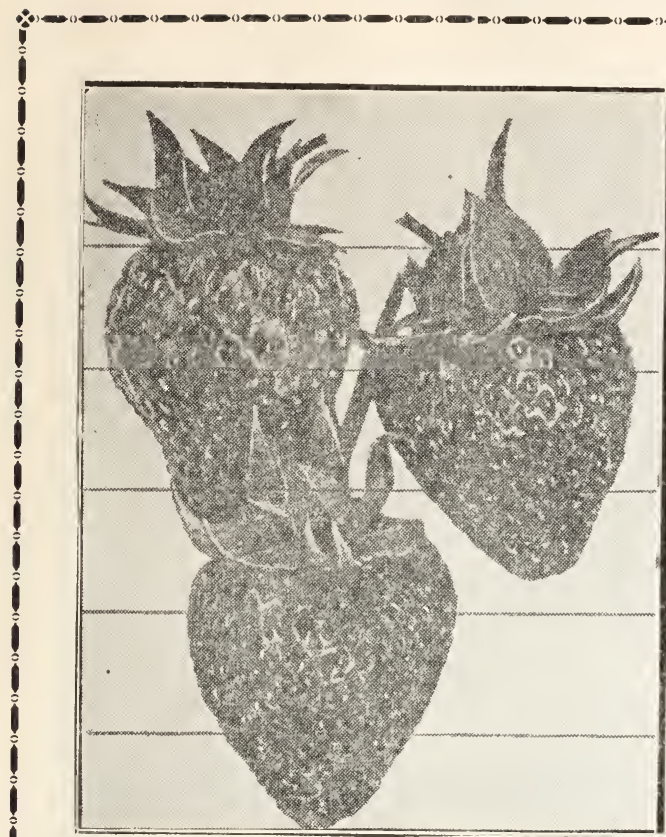

BLAKEMORE STRAWBERRY

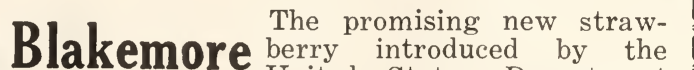
United States Department of Agriculture. No variety is more prolific in setting a good bed of plants and none is more healthy. Ripens from two to four days ahead of Missionary. Blakemore is more productive than Missionary and much more productive than Klondyke.

Perhaps the most outstanding characteristic of Blakemore is its firmness and ability to stand up in shipping. It seems to us that this variety should certainly replace Klondyke because where it has been tried it is better than Klondyke in every way, being a better shipper and going into market with a brighter, fresher look than Klondyke or Missionary.

It has been found also that Blakemore will mature its crop of fruit and be through in a much shorter season than Missionary or Premier, and the average size has been considerably better than Missionary. Price, $\$ 1.25$ per 100 , or $\$ 10.00$ per 1,000 .

Aroma Strawberry $\begin{aligned} & \text { The famous berry } \\ & \text { grown by McCrack- }\end{aligned}$ en County Berry Growers Association. Brings highest prices on all Northern markets. Genuine Aroma plants. Price, 100 for $\$ 1.00$.

Premier. Fine, large, early. Per $100 \$ 1.00$.

Postage or Express Extra. Write for prices on larger quantities.

Mastodon Everbearing Strawberry. The largest everbearing Strawberry yet introduced, sometimes run as large as 5 inches around, very uniform as to size and at no time do they run small. They are just as large in September, October and November as they are in July and August the first of the everbearing season. This uniform large size all through the everbearing season is one of the outstanding features of the variety.

HOW THEY BEAR

First crop: Set plants in April (Spring) begin picking ripe berries in July (90 days) continue through August, September and October.

Second crop: This comes next Spring during May and June.

If you will at least plant a few of this wonderful large everbearing Strawberry you will always continue to grow the Mastodon. Price: 25 plants $\$ 1.00,50$ plants $\$ 1.50,100$ plants $\$ 2.00,1,000$ plants $\$ 15.00$.

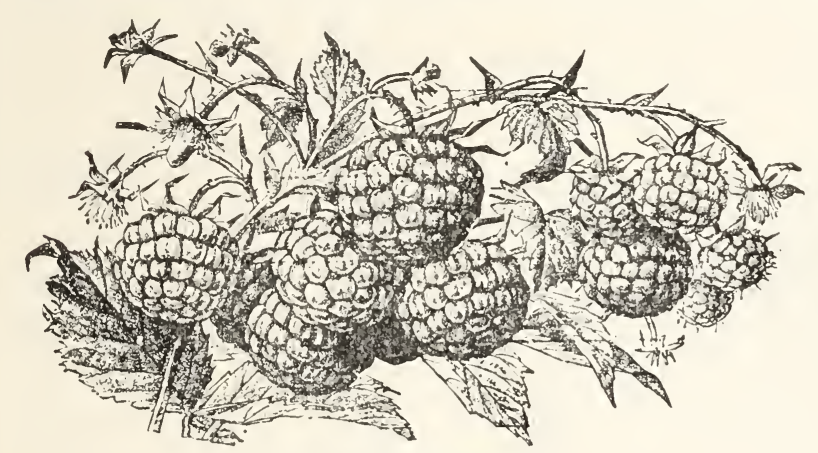

LATHAM RASPBERRY

\section{Latham-The Big Red Raspberry}

A BIG MONEY MAKER FOR BERRY GROWERS

The ability of Latham to produce so heavily, together with the fine appearance of the fruit and its splendid shipping qualities make it one of the most profitable Red Raspberries now grown.

Its extreme hardiness and splendid vigor insure big crops. It stands shipping well and tops the market. It combines all of the good qualities for profitable berry raising.

\section{EASY TO GROW}

Latham Raspberries can be easily grown in the home fruit garden and they require little care.

Set red raspberry plants $3^{\prime}$ to $5^{\prime}$ apart in rows

$6^{\prime}$ to $8^{\prime}$ apart. Plant 2 or 3 inches deeper than they were in the nursery. Cut back all stems as soon as planted to within 1 to 3 inches of the ground. Don't let any fruit set first year. Cultivate well between the rows to destroy weeds and sprouts, not allowing the new shoots to make rows over 6 to 8 inches wide. After fruiting cut out old canes and burn, leaving 6 or 8 vigorous new ones to grow for fruiting the following year. In the spring cut off the top 12 inches or possibly more of previous season's growth to srong, well ripened wood.

Start right! Plant LATHAM (Redpath Strain) Mosaic-free Stock. Per $100 \$ \$ 4.00$. Write for prices in large quantities.

St. Regis, everbearing red, 5c each; per $100, \$ 4.00$.

King Red, large, 5c each; per $100, \$ 4.00$. Cumberland, black, 5c each; per 100, $\$ 4.00$.

\section{DEWBERRY}

THE NEW YOUNG DEWBERRY

A hybrid Dewberry originated in Louisianna, bears larger fruit than the popular Lucretia variety, exceptionately f i n e quality. The berry is an attractive deep wine color. It has been found resistant to Anthracnose disease, and has been found especially suitable for culture in Southern states. This Dewberry has attracted very much attention because of its exceptional qualities of both its fruit and plant. Prices: 3 plants for $25 \mathrm{c}$, per $100 \$ 6.00$.

Lucretia. 5c each, per $100 \$ 3.00$. Postage or express prepaid.

\section{BLACKBERRY}

Eldorado, 6c each; per 100, \$5.00. GOOSEBERRY

Downing, 25c each. 


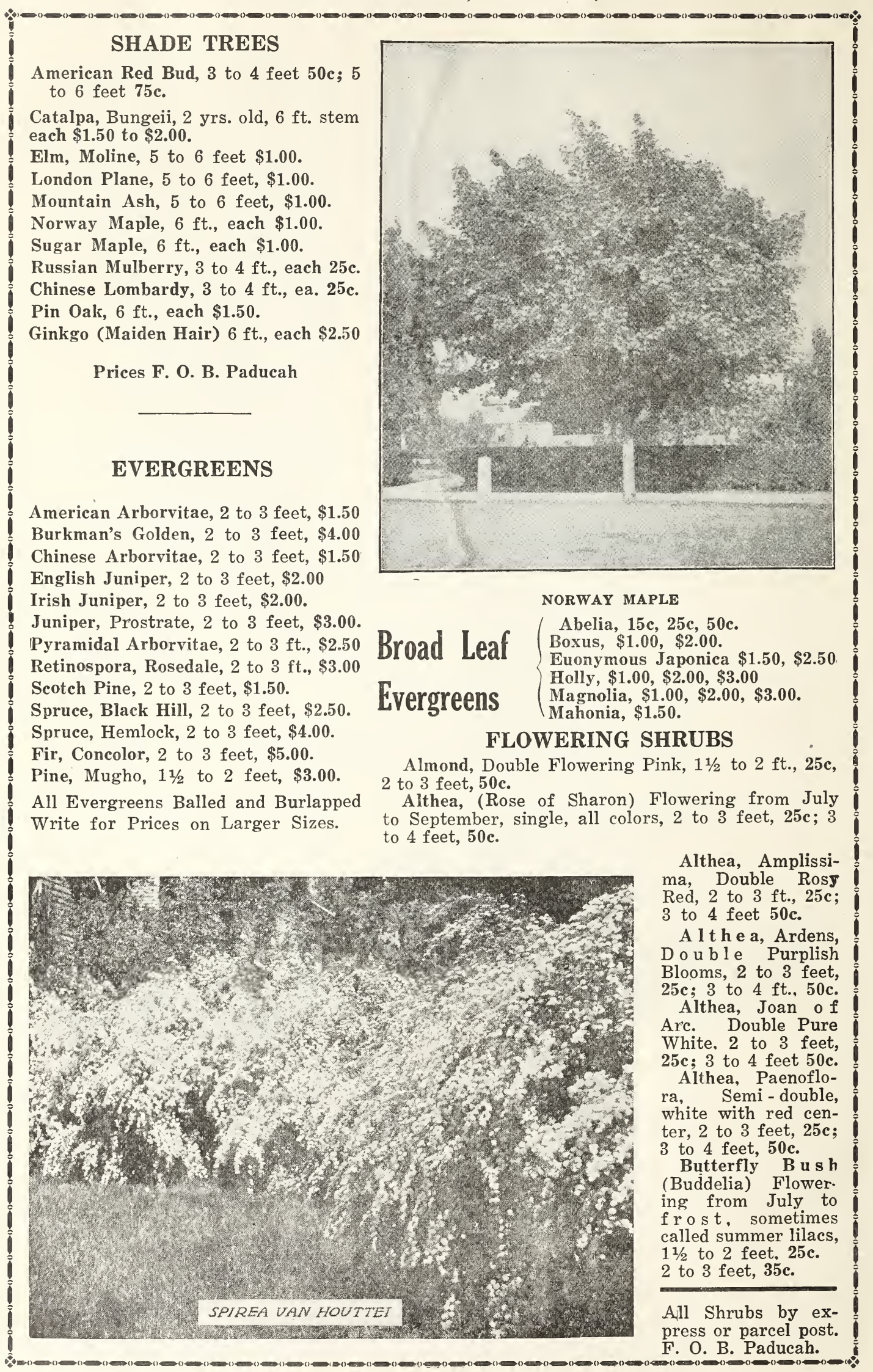




\section{FLOWERING SHRUBS}

Betchel's Flowering Crab. 2 to 3 ft. $\$ 1.00 ; 3$ to $4 \mathrm{ft}$. $\$ 1.50$.

Calycanthus (Sweet Shrub) small double purple blossoms, very fragrant, $1 \frac{1}{2}$ to 2 feet, $25 c$.

Crepe Myrtle, flowering June until frost, one of the finest shrubs, colors, pink and crimson, $1 \frac{1 / 2}{2}$ to $2 \mathrm{ft}$. $50 \mathrm{c}, 2$ to 3 feet.

Deutzias, well known valuable shrub.

Deutzias, Pride of Rochester, tall upright growing with double white blossoms, slightly tinged with pink, 4 to 5 feet_.......

Deutzias, Crenata, pink flowers, 4

to 5 feet.

Deutzias, Gracilis, Dwarf White

Blossoms, 2 to 3 feet__-_._-_-50c

Dogwood White Flowering. 2 to 3

ft. $50 \mathrm{c} .3$ to $4 \mathrm{ft}$. $75 \mathrm{c}$.

Forsythia, among the first to bloom

in spring, bright yellow flowers.

Forsythia, Fortunei (Golden Bell) upright,

$11 / 2$ to 2 feet $25 \mathrm{c}, 3$ to $4 \mathrm{ft} . \ldots \ldots$

Forsythia, Suspensa, long curving branches,

$11 / 2$ to 2 feet

Honeysuckle (Bush)._-15c, 25c, 35c.

Honeysuckle Red Tartarian. 15c, 25c.

Hydrangea, P. G. Cone shape flower, blooming in August, white turning to bronze. $1 \frac{1}{2}$

to 2 feet.

Hydrangea, A. G. (Hills of Snow) blooms in

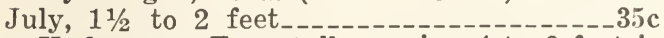

Hydrangea, Tree, tall growing 4 to 6 feet in

height, $3 \mathrm{ft}$. size -

Japonica (Japan Quince). Red. 35c, 50c. feet

Lilac, common white, 2 to $3 \mathrm{ft}$.

Spirea, Anthony Waterer, dwarf growing, crimson flowers, all during summer, 12 to 15 inches $25 \mathrm{c} ; 11 / 2$ to 2 feet

ANTHONY WATERER SPIREA

Lilac, French, named varieties, write for decription, 2 to 3 feet
Philadelphus (Mock Orange). Grandiflora, grows 10 feet tall, large white flowers, 2 to 3 feet -...-_-_-_-_-_-_-_-_-_-_-_35c

Philadelphus, Virginal, very large, semidouble white flowers, 2 to 3 feet_-_-_-_50c Pussy Willow, 25c, 35c.

Snowball (Viburnum Sterilis) well known

ld time shrub, 2 to 3 feet---_-_Spirea, white flowers, early spring, 2 to 3 feet, $15 \mathrm{c}$ ea., 3 to $4 \mathrm{ft}$. $25 \mathrm{c}$ each.

Spirea, Bilardi. tall growing, rich pink, flowers in July, $1 \frac{1 / 2}{2}$ to 2 feet.-.-.-- 25 c

Spirea Prunifolia (Bridal Wreath). 35c, 50c.
Spirea Thunbergi, low bushy plant, small star-like flowers early Spring, 11/2 to 2 feet._._-_._.

Tamarix, Odessiana, Silver foliage, pink blossoms, 2 to 3 feet $35 \mathrm{c}, 3$ to $4 \mathrm{ft}$. $50 \mathrm{c}$.

Viburnum, High bush Cranberry (Opulus) $1 \frac{1}{2}$ to $2 \mathrm{ft} .--35 c$ Viburnum, Opulus Sterilis (Common Snowball) 2 to $3 \mathrm{ft} 35 \mathrm{c}$ Weigelia, Candida, pure white flowers, 2 to 3 feet_-_-_-_50c Weigelia, Eva Rathke, flowers blood red, white stamens, 2 to 3 feet $50 \mathrm{c}, 3$ to $4 \mathrm{ft}$. $75 \mathrm{c}$.

Weigelia, Rosea, beautiful, pink flowers, late spring, 2 to 3 feet $35 \mathrm{c}, 3$ to $4 \mathrm{ft}$. $50 \mathrm{c}$.

Wisteria, Purple or White. 2 to $3 \mathrm{ft} .50 \mathrm{c}$.

\section{HEDGE}

California, 2 to 3 feet $\$ 4.00$ per $100 ; 3$ to 4 feet $\$ 6.00$ per 100 . Armoor River, 2 to 3 feet_-_._-_- $\$ 8.00$ per 100

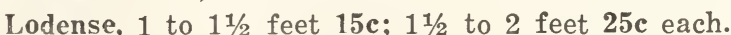

Barberry, (Thunbergi) 1 to $1 \frac{1}{2}$ feet $15 \mathrm{c} ; 1 \frac{1}{2}$ to 2 feet $25 \mathrm{c}$. Red Barberry, $1 \frac{1 / 2}{2}$ to 2 feet. Abelia, 1 to $1 \frac{1}{2}$ feet 15 c; $1 \frac{1 / 2}{2}$ to 2 feet $25 c$ each.

Shrubs by Express or Parcel Post F. O. B. Paducah

We have a full line of Ornamental and Flowering Shrubs. Write for prices and description on any Shrub wanted not listed above. Write for prices on larger or smaller sizes. 


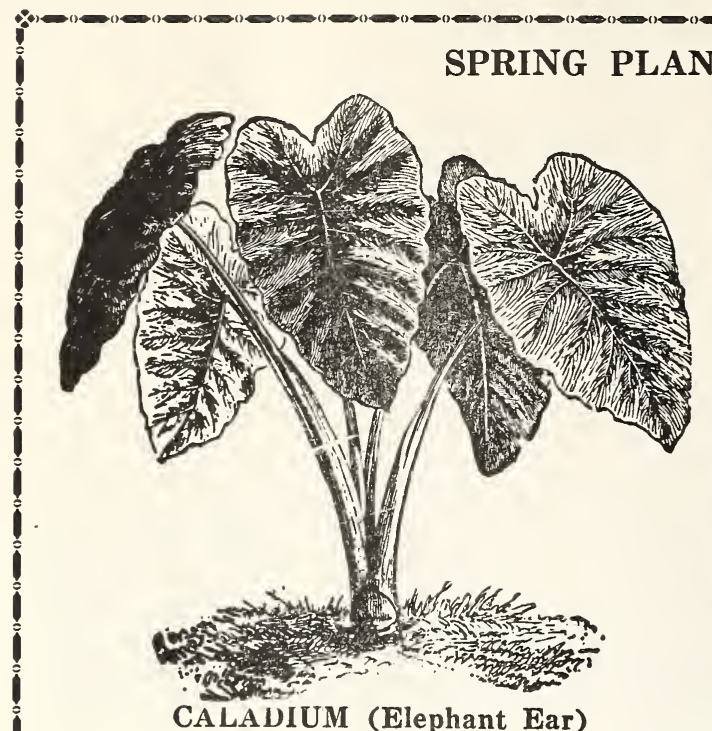

Price, first size 20c each; per dozen $\$ 2.00$, not post paid. Second size $15 \mathrm{c}$ ea., dozen $\$ 1.50$. Not postpaid.

$$
\text { CANNAS }
$$

Colossal, 4 to $5 \mathrm{ft}$, rich red blossom, green foliage. per dozen 75c.

Wyoming, beautiful shade of orange, bronze foliage, per dozen 75c.

King Humbert, $4 \mathrm{ft}$., scariet flowers, and bronze leaf per dozen $75 \mathrm{c}$.

President, $4 \mathrm{ft}$., large crimson flowers, green foliage, per dozen $75 \mathrm{c}$.

City of Portland, $31 / 2 \mathrm{ft}$, deep pink, green foliage, per dozen $\$ 1.00$.

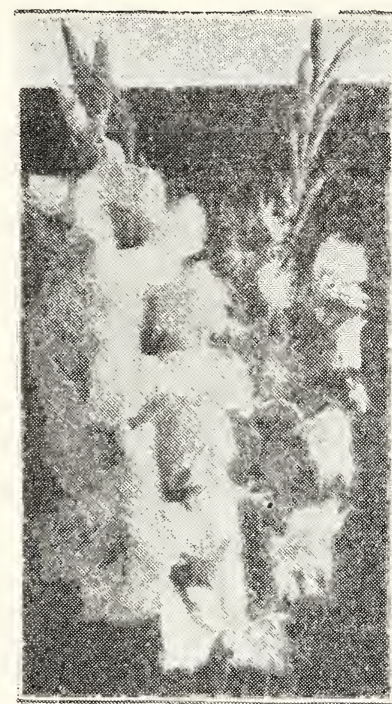

\section{GLADIOLUS BULBS}

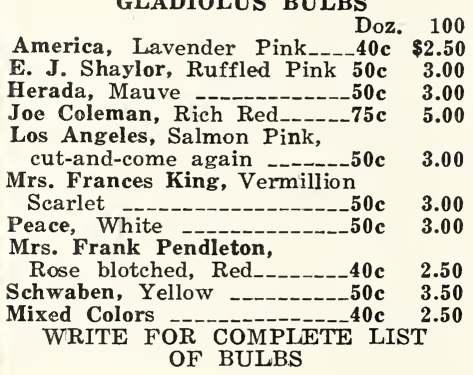

\section{IRIS}

8.9 Alcazor; S. Light bluish violet; F. Rich velvety crimson, each $\mathbf{1 5 c}$.

9.4 Ambassadeaur; S. Fascinating, smoky purple; F. Velvety purple maroon, orange bearded, each 50c.

9.4 Ballerine; S. Light violet blue; F. Deeper, very fragrant, blooms 5 inches long, each 50c.

7.5 Caprice; S. Reddish, purple; F, Deeper purple, each 10c.

7.8 Eldorado; S. Bronze shaded yellow; F. violet purple, touched with bronze yellow, each $\mathbf{1 5 c}$.

7.6 Florentina Alba, White, trace of pale blue, ea. 10c.

Flavencense, sulphur yellow, each 10c.

7.3 Her Majesty; S. Soft rose; F. Deeper rose, heavily veined, each 15c.

8.5 Isoline, lilac pink, bearded yellow, each 25c.

8.2 Lohengrin, large handsome silvery mauve flowers, each 10c.

7.9 Iris King; S. Old Gold; F. Rich crimson, bearded gold, each 15c.

9.0 Lent A. Williamson, S. Very broad soft campanula violet; $F$, Very large velvety royal purple, gold beard, each $35 \mathrm{c}$.

9.1 Magnifica; S. Light violet blue; F. Deep reddish purple, fragrant, very large, each 50c.

8.5 Mother of Pearl, a pale bluish lavender, vigorous grower, free bloomer, each $35 \mathrm{c}$.

7.4 Mme. Chereau, pure white with broad clear border, each $10 \mathrm{c}$.
8.4 Monsignor: S. Bluish lavender; F. Violet with white penciling at throat, each $10 \mathrm{c}$.

8.8 Pallida Dalmatica, exquisite lavender blue, free flowering, each 25c.

7.2 Princess Vic. Louise; S. Sulphur yellow; F. Plum shaded primrose, each $10 \mathrm{c}$.

8.3 Prosper Laugier; S. Fiery bronze; F. Velvety ruby purple, each $\mathbf{1 5 c}$.

7.4 Queen of May; S. Lilac pink, each $10 \mathrm{c}$.

8.3 White Knight, pure white, each 35c. Walneri, light blue, each $10 \mathrm{c}$.

8.4 Rein Nixe; S. White very large; F, Rich violet purple, narrow white edge, each 25 c.

7.6 Sherwin Wright, golden yellow, each 15c. 


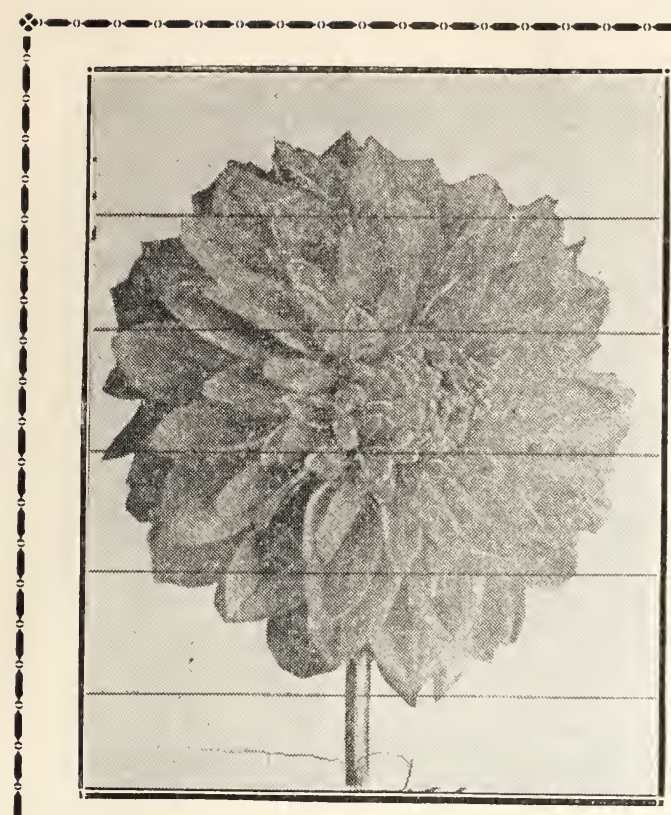

DAHLIA

\section{DAHLIA}

Plant any time in May or June in well worked soil. Lay tuber flat and cover about 6 inches deep, 3 feet apart, allow on stalk to grow from each tuber, pinch out middle bud when the second set of leaves has appeared, this will make the plant branch freely and very little or no support will be needed.

Amon Ra, (Decorative). Beautiful blend of Each Dozen copper, orange and scarlet, large blossoms_-_40c $\$ \$ 4.00$ Bashful Giant, (Decorative). Large Apricot with golden shading---_-_-_- $35 \mathrm{c}$ Jean Keer, (Decorative). White-_-_-_-_-_ 35c 3.50 Jersey Beauty, (Decorative). Large pink__-_35c 3.50 Jersey Beacon, (Decorative-. Large Chinese

red _-

Mrs I. De Ver Warner, (Decorative). Orchid color, very large

Jane Cowl, (Decorative). Orange buff and old gold, each Pride of California, (Decorative). Large crimson red Queen Mary, (Decorative). Rose pink Sagamore, (Decorative). Saffron Yellow_-_-_50c Frank A. Walker, (Decorative). Lavender pink -

Double Red -

Double Pink -

Double Yellow ---

Double White

\section{FLOWER SEED}

CULTURE-Most flower seed should be planted shallow and kept covered with old cloth or jute sacks until sprouted, to prevent drying out. Plant in rows for easy tending and keep weeds pulled out. Be sure first that they are weeds. With slow growing seeds it is a good plan to drop a few cabbage or radish seeds, as they will come up quickly and mark the rows for you. Use pulverized sheep manure.

Unless otherwise specified, the flowers are in mixed colors, as most people prefer them that way. On some we offer separate colors, but in such cases the colors are named.

Flower seed in $10 \mathrm{c}$ pkts. 6 for $50 \mathrm{c}$, or 12 for $80 \mathrm{c}$, in bulk, $1 / 2$ ounce at ounce prices. Postage prepaid by us.

Everyone should plant a flower bed, as it encourages the little ones and there is nothing more attractive than a pretty flower bed.

Abronia (Sand Verbena). Hardy Annual, resembling the Verbena in its style of growth, of trailing habit and thrives in poor soil and dry location. Its fragrant flowers are borne in clusters. Mixed. Pkt. 10c.

Ageratum. One of the best Summer blooming plants, has soft Lavender Blue Flowers. Pkt. 10c.

Alyssum, Annual. Popular little plants for edging or massing, blooming profusely all summer. Begins blooming very early in the spring covering itself with clusters of small flowers. White. Pkt. 10c, oz. 25c.

Alyssum Saxatile, (Basket of Gold). Hardy perennial. 6 to 12 in. high. Produces a mass of golden yellow flowers very early. One of our best rock plants and good for borders. Pkt. $10 \mathrm{c}$.

Alyssum. Lilac Queen. Deep lavender lilac. Pkt. 10c.

Amaranthus, Annual. The leaves and stems are different shades of red, blended with green. Mixed varieties. Pkt. 10c, oz. 35c.

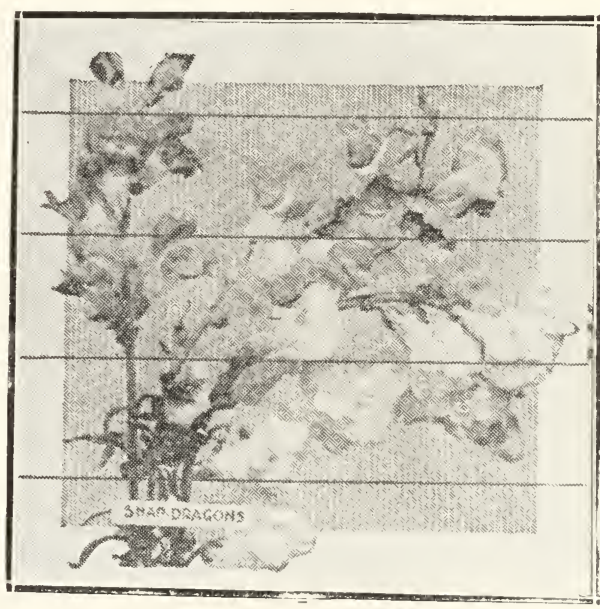

\section{ANTIRRHINUM}

Antirrhinum, (Snapdragon). An old fashioned annual flower that has been greatly improved in late years useful alike for garden decoration and cutting.

Ruby, Velvety Ruby, red, Pkt. 10c.

The Rose, rose, pink, Pkt. $10 \mathrm{c}$.

Appleblossom, Rosy pink, white throat, pkt. 10c.

Purple King, Velvety dark garnet, pkt. 10c.

old Gold, Golden yellow, old rose throat, pkt. 10c.

Copper King, Velvety copper scarlet, pkt. 10c.

Snowflake, Pure snow white, yellow tube, pkt. 10c. Mixed, pkt. 10c.

Aquilegia, (Columbine). Hardy Perennial, will bloom from seed the first year if started early. By planting in August or September will make vigorous plants and bloom profusely the next spring. Very easy to grow. They can be used for cut flowers.

Long Spurred Hybrids mixed, pkt. 10c. 


\section{FLOWER SEED-Continued}

\section{ASTERS}

One of the best Annual flowers grown. Excellent for bedding, and unsurpassed for cut flowers. It is quite easy with a little care in selecting varieties in time of planting to have Aster's in bloom from early July to killing frost. For early blossom, you should plant seed in February or March in cold frames transplanting out-doors after danger of frost. For late planting, sow seed out-doors in May or June.

Giant Crego. Also known as Ostrich Plume. Blooms in midseason bearing fluffy flowers of immense size.

Rose, pkt. 10c. Purple, pkt. 10c.

White, pkt. 10c. Mixed, pkt. 10c.

Giants of California. A midseason late flowering strain. Plants grow 3 to $3 \frac{1}{2}$ feet high. Single mixed, pkt. 25c.

American Branching. The plants are branching type with full flowers on long strong stems. A midseason variety. Ruby red, rose, white, purple. Pkt. 10c.

Balsam (Lady Slipper) Annual. A very popular old time flower. For best growth, Balsam should be planted 15 to 18 inches apart. $10 \mathrm{c}$.

Double Camellia Flowered, Mixed, Pkt. * * * * *

Calendula (Pot Marigold). Hardy Annual. Grows about one foot high. Wonderful profusion of flowers ranging from Ivory to Orange. Fine for cut flower, make attractive beds and border's, Pkt. 10c.

Candytuff. Hardy Annual. Very attractive bedding plant used for Rockeries, splendid cut flowers, lavender, crimson, rose, white, rose cardinal. Mixed, pkt. 10c.

Cannas. (Indian Shot). Crosby's large flowering dwarf. Pkt. 10c.

Calliopsis (or Correopsis) Annual. Very graceful bright flowering border plant, splendid cut flowers. Will grow in most any type of soil. Yellow and rich brown. Mixed. Pkt. 10c.

Canterbury Bells. Annual. An old favorite hardy plant, has large bell shaped flowers. Colors including shades of blue, rose and white. Pkt. 10c.

Carnation. (Marguerite), Perennial. These lovely fragrant carnations produce fine double flowers. All colors. Pkt. 10c.
Centaurea (Cornflower or Bachelor Button). A very large hardy flowering Annual. Blooms all summer long. Will grow in most any garden soil, but if soil is rich the flowers will be large and have longer stems. Mixed colors. Pkt. 10c.

Centaurea (Sweet Sultan). Our strain of Sweet Sultan is of the finest for cut flower purpose. Colors run from white, red, blue, lilac, etc. Should be planted early in order to flower before hot weather. W'hen cut and put in water will last several days in good condition. Pkt. 10c.

Centaurea (Dusty Miller), Annual. For bedding, hanging baskets and edging. Pkt. 10c.

Chrysanthemum, Annual. Flowering freely during summer and fall. Quite ornamental. Pkt. 10c.

Clarkia, Annual. A pretty and easily grown flower. Good for bedding and cut flowers. They are rapid growers and constant bloomers. Flowers. rose. white red, pink and purple. The double flowers appear on long spikes which make beautiful cut flowers. Will grow in shade or sun. Mixed, Pkt. 10c.

Cleome (Giant Spider Plant). A showy garden Annual, producing a curious head of flowers of bright rose color. A good bee plant. Pkt. 10c.

Cock's Comb, Annual. The combs often grow 8 to 10 inches across the top. Pkt. 10c.

Coleus, Annual. These showy plants are grown for their foliage. Pkt. 10c.

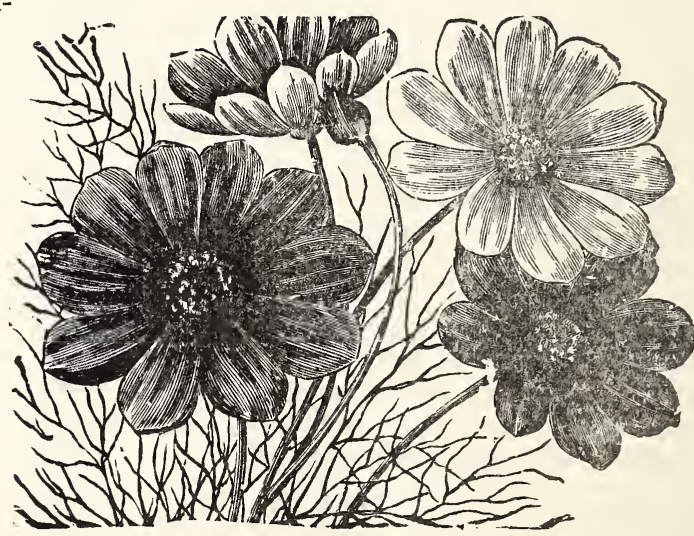

cosmos

Cosmos. One of the most attractive plants for the garden blooming in early summer and continuing until frost. Has beautiful feathery foliage. Single Early Mixed, Pkt. 10c. Pink. crimson, white, Pkt. 10c. Double Early Mixed, Pkt. 10c. Miniature Yellow, Pkt. 10c. 


\section{FLOWER SEED-Continued}

Shasta Daisy, Perennial, Large snow white flowers with yellow centers borne on long wiry stems, blooms abundantly until frost. Good for cut flowers. Pkt. 10c.

Dahlia. Annual. A favorite for autumn flowering, blooming the first season from seed if started early. Pkt. 10c.

Dianthus. (Pinks), Biennial. Few flowers can equal these in profusion and bloom. Double mixed. Pkt. 10c.

Delphinium. With their long clustered spikes of charming shades are most effective when planted in groups and make strikingly attractive back grounds and most desirable for cutting. Delphinium is a hardy Perennial. Mixed color, Pkt. 10c.

Digitalis (Foxglove). A tall growing biennial with large leaves and spikes of varicolored and spotted flowers. Fine for borders or back ground. Mixed color, Pkt. 10c.

Eschscoltzia. Annual, (California Poppy). A showv. free-flowering plant, blooming throughout the season. Pkt. 10c.

Euphorbia, Annual. (Snow on the Mountain). Strong growing annual, the rich green leaves being heavily margined with white. Pkt. 10c.

Gillardia, (Blanker Flower), Perennial. Splendid bedding border and cut flower, has large beautiful flowers which blooms until frost. Mixed color, Pkt. 10c.

Godetia. Useful for beds or mixed borders. The flowers are cup shap ad and do well in most any soil. Pkt. 10c.

Gypsophila, Annual. (Baby's Breath). A greatly esteemed hardy plant, bearing dainty mist-like white flowers. Used for mixing with other large flowers in bouquets. Pkt. $10 \mathrm{c}$.

Helichrysum. Annual. Sometimes called straw flower. Large, full double daisy-like

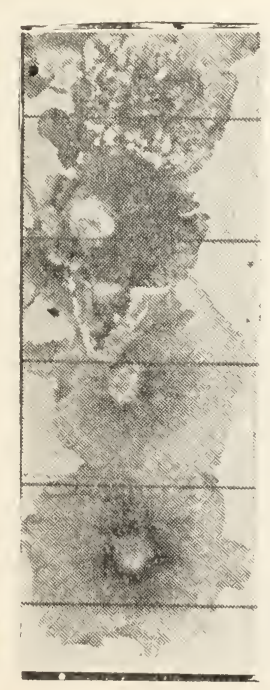
flower. Desirable as dried specimens and for use in making winter bouquets. Pkt. 10c.

Heliotrope, Perennial. Well known and much admired border and bedding plants, highly valued for the blue color and fragrance of their branching clusters of small salvershaped flowers. Pkt. 10c.

Hollyhock. Hardy perennial. This fine old fashioned flower is more popular each scason and you could not find a more beautiful flower in the whole garden than our improved strain of Hollyhocks. Makes a charming hedge or background. Colors pink, red, mixed. HOLYHOCKS
Kochia, Annual. Burning Bush). A very attractive quick growing foliage or hedge plant, bright green color. Early in the fall the bush turns to a fiery red. Pkt. 10c.

Lantana, Annual. Shrubby plant with Verbena-like flowers, may be grown in pots or set out in open. Colors range from orange, white, to rose and red. Mixed. Pkt. 10c.

Larkspur, Annual Delphinium, produces long cluster spikes of beautiful flowers. Very desirable for bedding and cut flowers. Colors, lilac, dark blue, pink. Mixed, Pkt. $10 \mathrm{c}$.

Lobelia, Annual. A popular border plant. Flowers blue and white. Pkt. 10c.

Lupinus. Free flowering, early grown annals, with long spikes of rich and various colored pea-shaped flowers. Mixed. Pkt. 10c.

Marigold, Annual. A hardy plant in dwarf and tall varieties. Foilage bright green and deeply cut, flowers are various shades of yellow and brown.

Tangetes Miniature, Pkt. 10c.

French Dwarf or Tall, Pkt. 10c.

Marvel of Peru, Annual. (Four O'clock). Well known and popular flower. Pkt. 10c.

Mignonette. A quick growing sweet scented and very popular Annual, produces large dense cone-shaped flower spikes of white, yellow and red shades. Used principally for combining with more showy flowers in bouquets on account of its delightful fragrance. Pkt. 10c.

Mourning Bride, Annual. (Scabiosa). An old fashioned but most attractive flower. Its great abundance and long succession of richly colored, fragrant blossoms on long stems make it one of the most useful decorative plants of the garden. Pkt. 10c.

Nasturtium. The most popular of all Annuals, really does best where soil is not too rich. The dwarf varieties make the most beautiful beds or bordering plant also for porch boxes. The trailing or tall varieties are used for covering stumps, trellises or low fences. Mixed colors, Pkt. 10c.

Nicotiana, Annual. (Sweet Scented Tobacco Plant). A very beautiful and fragrant tall border plant flowering throughout summer and fall. Mixed. Pkt. 10c. 


\section{FLOWER SEED-Continued}

Pansy, Annual. Pansies are now produced in almost infinite color and markings. Giant flowering. Especially fine mixture of very large blotched and stained flowers. Pkt. 10c, oz. \$2.50. All colors mixed.

Petunia. During the whole season it is covered with large, showy blossoms which are always bright and fresh in spite of heat and drought. The flowers are of an almost infinite variety of colors and markings, and quite as varied in form, fringed and plain, double and single. Hardy Annual.

Giant of California. Choicest Ruffled Mixed, Pkt. 25c.

Howard's Star. Purplish violet with white stars, Pkt. 10c.

Rosy Morn. Pink with white throat, Pkt. 10c.

General Dodds. Velvety blood red, Pkt. 10c.

Balcony Blue. Deep velvety blue, Pkt. 10c.

Single Mixed, Pkt. 10c.

Double Mixed, Pkt. 50c.

Phlox (Drommondi). A very popular free blooming Annual. Colors ranging from white to deepest scarlet, fine for cutting and bouauets, unsurpassed for bedding in masses, Pkt. $10 \mathrm{c}$.

Poppy. A showy magnificent flower with

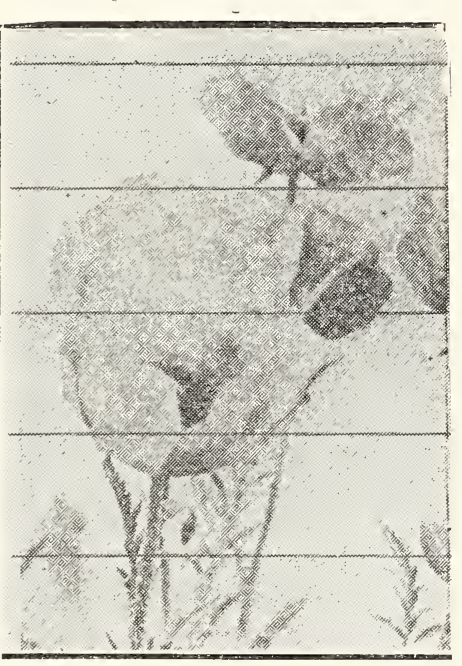
large silky blooms on tall stalks i n many bright colors. Some a $\mathrm{re}$ hardy Annuals, others a $\mathrm{r} \mathrm{e}$ Perennials. Shirley

Mixed.

Very large single flowers in delicate shades of colors, Pkt. 10c.

American Legion.

Brilliant orange scarlet with yellow, Pkt. ORIENTALE POPPY 10c.

Double Mixed, Pkt. 10c.

Orientale. Perennial, immense red, salmon and pink shades, Pkt. 10c.

Zinnia. The most popular Annual. Has a wonderful range of colors, blooming from spring until killed by winter frost. Extremely double flowers with long stems and good keeping qualities. The easiest of all flowers to transplant. We have several types of Zinnias. Giant flowered Zinnia produces the largest flowers of all Zinnias, are profused bloomers. No flower garden is complete without some of these large flowering Zinnias. Colors, rose, yellow, crimson, white, lavender, mixed colors, Pkt. 10c.

Dahlia Flowered Zinnia. This new type of Zinnia has become very popular. Our strain of these is like the balance of our flower seed, the best obtainable. Mixed colors, Pkt. 10c.

Lilliput Pom Pom Zinnia. This small double flowering Zinnia is very popular for cutting, bedding and lining borders. Mixed colors, Pkt. 10c.
Portulaca, Annual. (Moss). Succeeds best in sunny places and produces flowers of almost every color. Single mixed. Pkt. 10c, double mixed, Pkt. 10c.

Ricinus (Caster Bean) Annual. Large tropical foliage plant highly ornamental of stately growth. Large leaves of glossy green, Pkt. 10c.

Salpiglossis, Annual. Very showy bedding border plants, with richly colored, funnel-shaped flowers, which are borne on long, graceful stems. Pkt. 10c.

Salvia (Scarlet Sage). Hardy Annual. These popular flowers are very ornamental, strong grower and free bloomer of fiery red or crimson flowers, borne in spikes and continues to bloom until frost. Pkt. 10c.

Statice. A splendid hardy perennial used for rockeries and borders and producing panicles of graceful flowers of the everlasting type, can be dried and used for winter bouquets. Pkt. 10c.

Sunflower (Heilanthus), Annual. Valuable as a screen to hide unsightly places and as a background for lawns. Pkt. 10c.

Sweet Violets. Perennial. This beautiful and fragrant flower is a favorite everywhere; the plants should be grown in a rich, moist soil. Plkt. 10c.

Sweet William, Perennial. Fine for display in beds or borders. Many brilliant colors. Pkt. 10c, oz. 50c.

Verbena, Annual. In the varieties may be found every color from white through lilac rose to purple. All colors mixed. Pkt. 10c.

Vinca (Periwinkle). Annual. An old favorite, free flowering, bedding or border plant, produces a round single flower and glossy foliage of dark green. Mixed colors, Pkt. 10c.

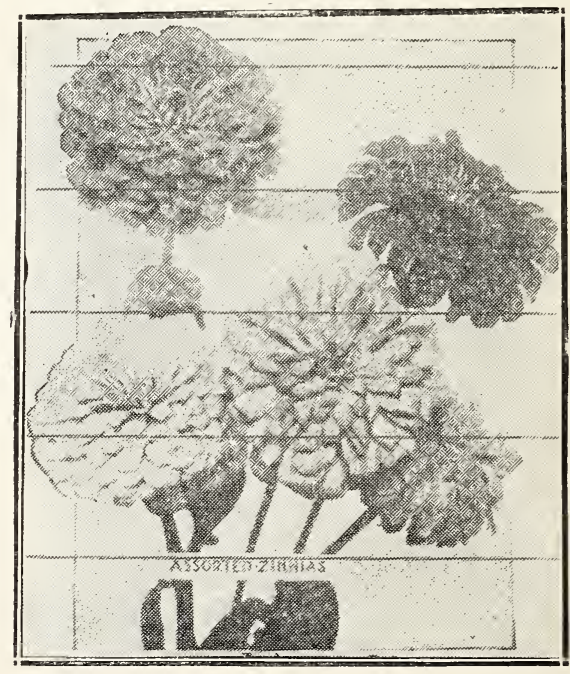

Z1 NNIA 
Be sure to plant vines to have plenty of shade during the summer

Balsom Pear. A very desirable climber. When kept in alcohol makes a most effective pain cure and healer of cuts, bruises, etc. Pkt. 10c, oz. 50c.

Cardinal Climber. Annual. A most beautiful vine of very rapid growth, with delicately cut, fern-like foliage and producing in abundance dainty star-shaped, scarlet flowers. Pkt. 10c.

Coboea, Scandens. Half hardy perennial; a rapid growing climber with handsome dark green foliage and bearing large bell shaped flowers. Blossoms are green at first but change rapidly to a beautiful, deep violet blue. Desirable for covering trellises. verandas, etc. Grows about 25 to 30 feet long. Pkt 10c.

Cypress Vine. One of the prettiest in cultivation. Sow the seeds thickly, so as to make a thick growth. White and scarlet blooms. Pkt. 10c, oz. 50c.

Hyacinth Bean. Climber of quick growth, bearing large clusters of purple and white flowers, which are followed by bright, purple pods. Pkt. 10c, oz. 20c.

Kudzu Vine, A. The most rapid growing vine in cultivation. Will grow from 20 to 40 feet in one season. Has large heart-shaped leaves and small, rosy-purple pea-shaped flowers. Pkt. 10c.

Moonflower. (Evening Glory). Beautiful rapid climber. Very large, white flowers, which open in the evening and on cloudy days. Before planting it is best to file a small hole in one end through the outer hulk size, the standard, and wings waved or frilled and the general effect remarkably graceful growth and remain in bloom for a longer period of time than the Grandiflora sorts. Also have longer stems.

Super Mixed

Pkt. Oz.

Avalanche, White

Hero, Rose Scarlet -..-_-_-_-_10 25c

Powerscourt, Clear Lavender-.-10 25c

I Pinkie. Large Rose Pink _._____-_10c 25c

Mary Pickford, Salmon Pink, Cream

Tint

I Idyl, Cream Salmon Pink

Olympia, Purple -

Reflection, Clear Blue

What Joy, Deep Cream-

Warrior, Bright Red_._._._._-_-_10c

$25 \mathrm{c}$

$25 \mathrm{c}$

$25 \mathrm{c}$

$50 c$

EARLY SPENCER VARIETIES

Early Spencer

Early Blue Boy, Clear Blue

I Early Harmony, Lavender........10 $25 \mathrm{c}$

Early Giant, Rose, Deep Rose...-10 $50 \mathrm{c}$

Early Snowstorm, White _..._._10 25c

Early Springsong, Salmon Pink

I Early Torch, Deep Salmon, Orange 10c 25c

Vulcan, Cerise Red _.......... $10 \mathrm{c} 25 \mathrm{c}$

Morning Glory, (Common). All colors mixed. Pkt. 10c, oz. 20c.

Maderia Vine Roots. A popular climber, will run 20 feet or more. Doz. 75c.

Gourds. All varieties, mixed. Pkt. 10c.

\section{$25 \mathrm{c}$} $5 c$
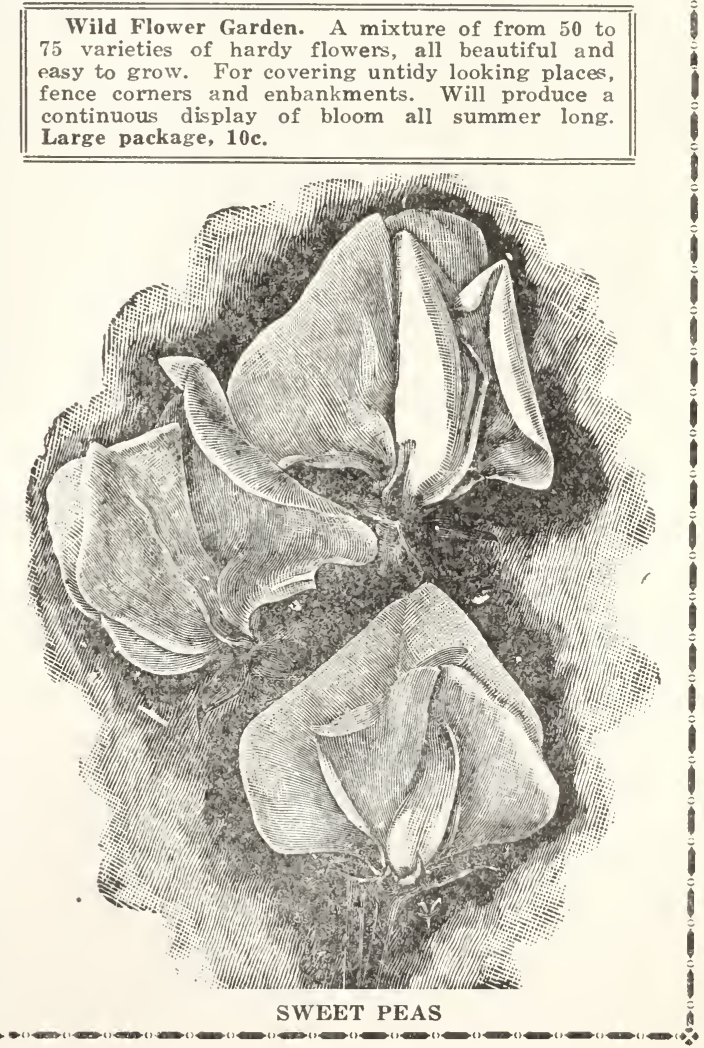


\section{ORCHARD SUPPLIES}

We Sell BEAN and F. E. MEYERS POWER SPRAY OUTFITS

If interested, write for complete catalog on each

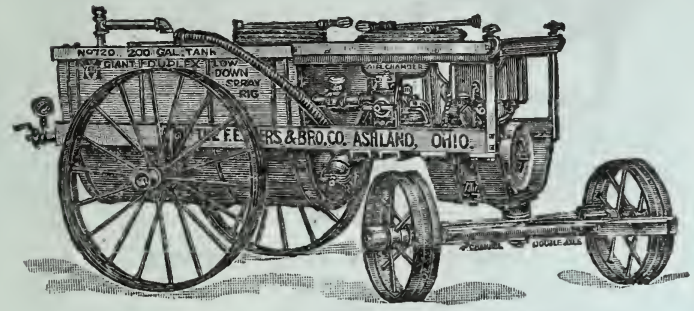

Myers' Giant Duplex Power Spray Rig No. 720

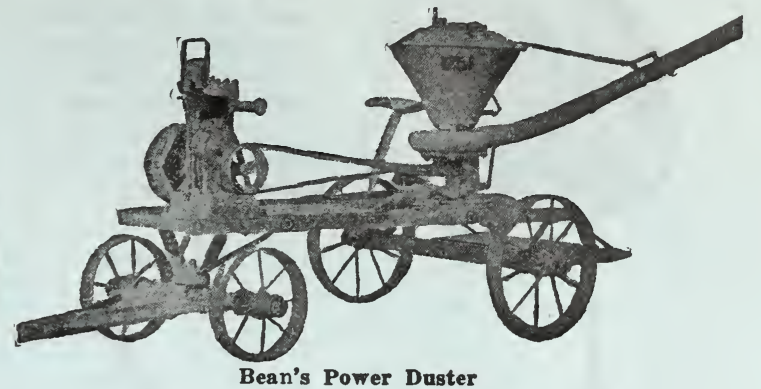

POWER DUSTERS-Bean and Niagara

\section{REDDICK \\ MOLE TRAPS}

They Never Fail to

Catch

\section{Price $\$ 1.00$}

Each

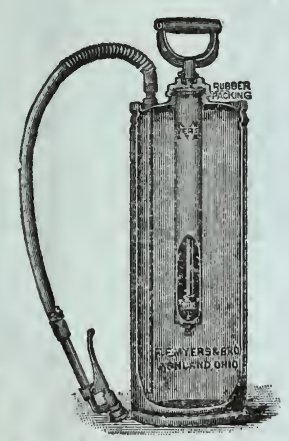

No. 1297 and No. 1296 MYERS' COMPRESSED AIR SPRAYER

For spraying vegetables and small trees and poultry houses. No. 1296-2 $1 / 2$ Gallon Capacity, $\$ 5.00$.

No. 1297-41/2 Gallon Capacity. $\$ 6.00$.

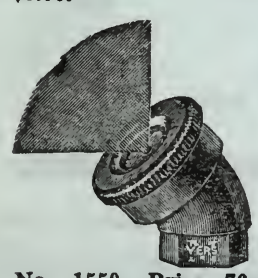

No. 1559, Price 70c

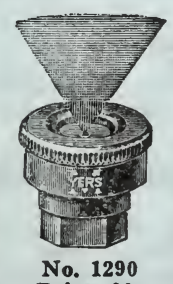

Price 60c

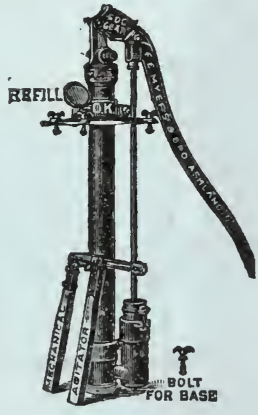

No. R308-B

With one lead of 15 feet of 7 ply 3-8 inch discharge hose and one Fembro nozzle. Price $\$ 25.20$.

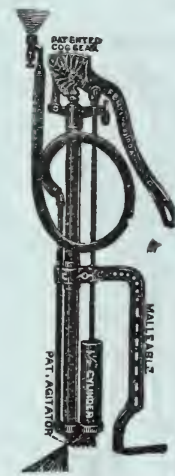

No. 324 MYERS' BUCKET SPRAY

Can be used in bucket or attached to top of keg. Price $\$ 6.00$

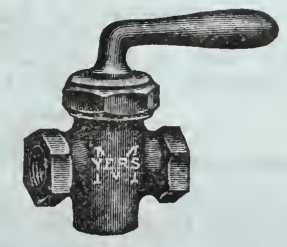

No. 1283 , Price $\$ 1.00$

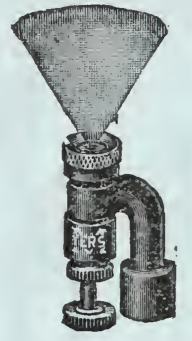

No. 1564

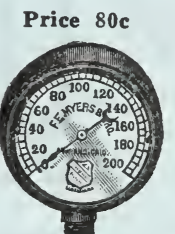

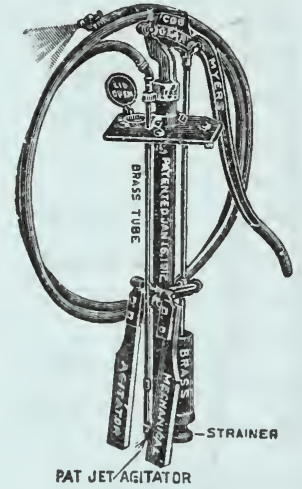

No. 318-B

This is one of the best one-lead barrel sprays on the market. Fitted with 15 feet of Hose, Nozzle, ShutOff and 8-foot Rod. Price $\$ 16.00$.

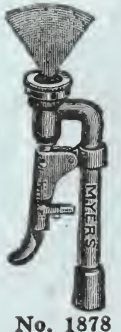

No. 1878

THE MYERS' PRESSURE GAUGE

No. 1721-Built especially for Myers' Pumps ; in three sizesstate which size wanted.

100 lb. 3 " Diameter, Price_- $\$ 2.50$ 250 lb. 3 " Diameter, Price_- 2.50 400 lb. $31 \frac{1 / 2}{}$ " Diameter, Price_- 3.50

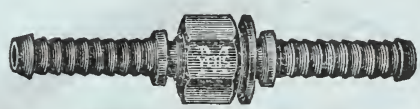

No. 1284, Brass Hose Coupling, Sure Grip, 60c each.

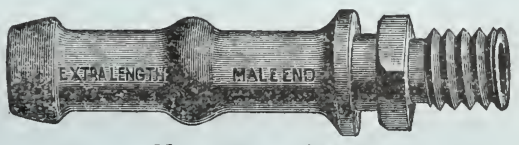

No. 1325, Price 35c 

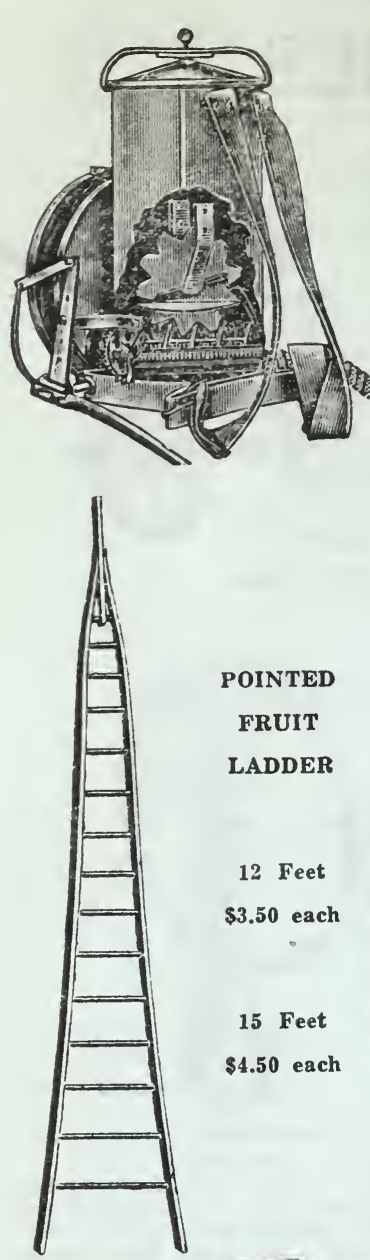

POINTED

FRUIT

LADDER

12 Feet

$\$ 3.50$ each

15 Feet

$\$ 4.50$ each

Is the most powerful portable duster built. One man carrying and operating the American Beauty can dust trees up to 25 feet in height and thoroughly cover from 5 to 15 acres per day in orchard work and corresponding acreage in truck crops.

\section{Price $\$ 20.00$}

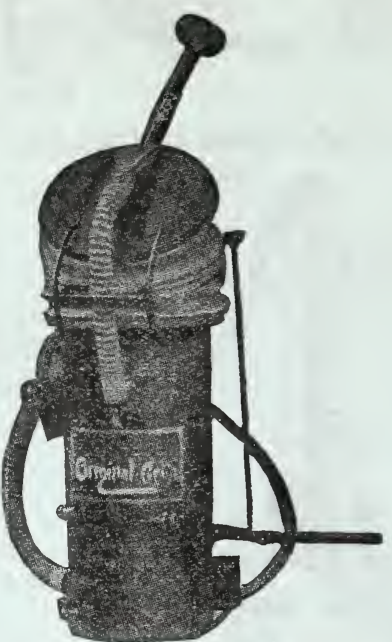

PLATZ GREEN DUSTER Single Acting $\$ 17.00$ Each Double Acting \$20.00 Each Write for full Description
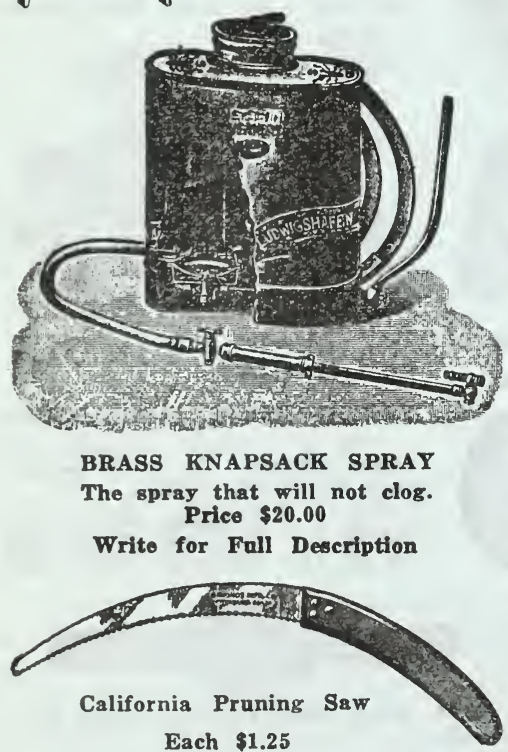

PLATZ GREEN HAND DUSTER

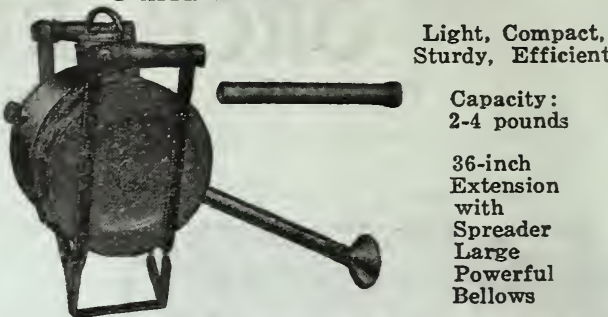

Easy to work and regulate. Practically indestructible -wearing parts can be readily replaced. Excellent for dusting either hill crovs or underside of foliage. Handles any dust that can be used in larger outfits. Price $\$ 6.00$

\section{THE TIFFANY TREE PRUNER}

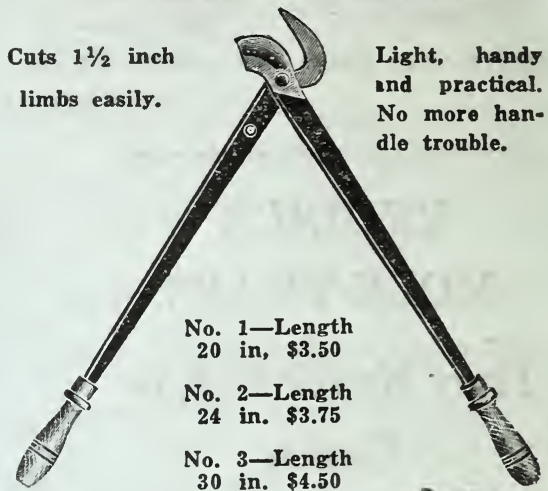

o. 3-Length
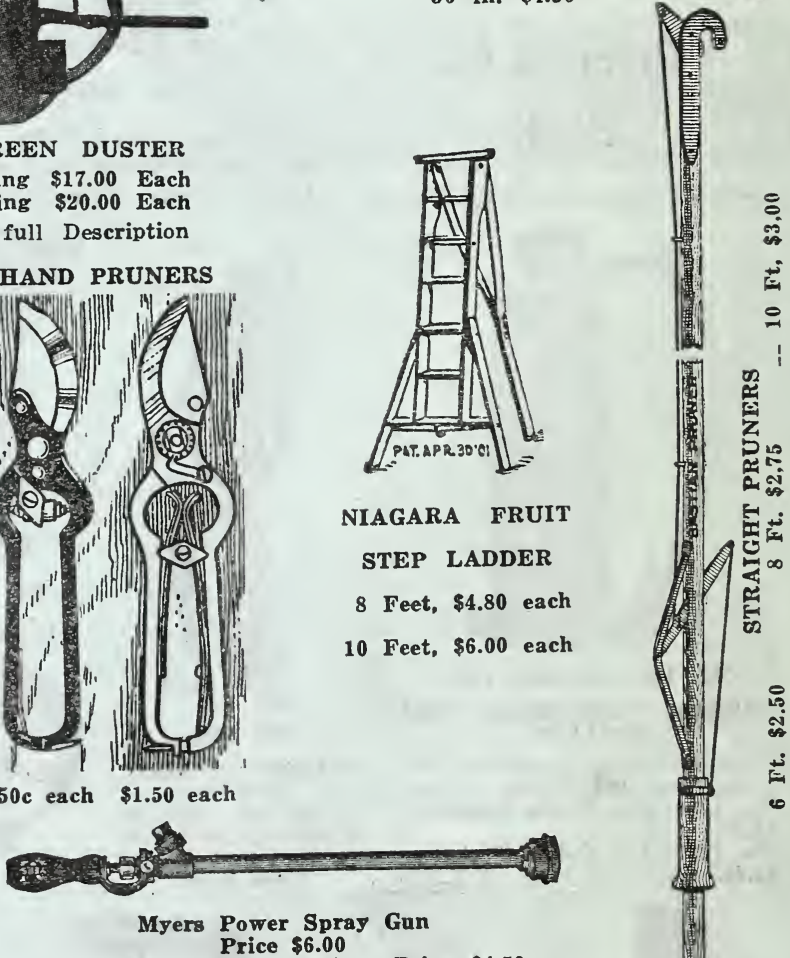
$10-F$ t. Extension, Price $\$ 4.75 ; 12-F t$. Extension, $\$ 5.00$

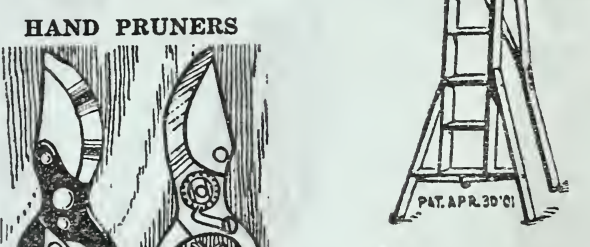

BRASS KNAPSACK SPRAY

The spray that will not clog. Price $\$ 20.00$

Write for Full Description

No. 1536, 8 Ft. Extension, Price $\$ 4.50$

NIAGARA FRUIT STEP LADDER

8 Feet, $\$ 4.80$ each

10 Feet, $\$ 6.00$ each F1G. 1535 No. $1535, \&$ ft. pipe extension with lever shut-off cock $\$ 1.80$ lever shut-off cock. ALL PRICES F. O. B. PADUCAH 


\section{FEED}

FERTILIZERS

\section{YOPP SEED CO.}

318-320 South Second St.

PADUCA H, KENTUCKY

We are pleased to quote you today's prices on Seed, Produce and Poultry Supplies, F. O. B. Paducah. Terms, Net Cash.

\section{ASK FOR SPECIAL PRICES ON LARGE QUANTITIES}

Cotton bags charged at cost and not returnable.

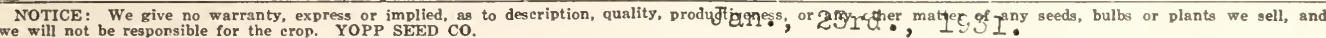

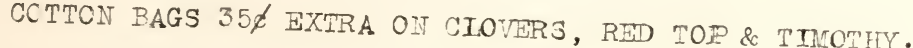

CIO $\sqrt{\mathrm{E}} \mathrm{RS}$

UHIFE Sapling, - - - - -318.00 CIIEF Red Native, - _ -17.00 PADUKE " " - - 16.00 CHIEF Alsike, - - - - - 15.06 FLDUKE " - - - - 14.00 CHITP Alfalfa, $-----\overline{-}$ - -52.50
PADUKE

SWEET CIONER (6O\# to Bu.)

White Blossom, HuIIed, _ Yellow " " - 6.60 Small Eots $2 \not$ Fer Ib.Higher. White Blossom, Unhulled $10 \not 2$ Ib.

WHITE CICVER, Chief - Lb. - .50 " $"$ " Easture "- 1 - .30

JAFAN CIOVER (Ies pedez Bu.- 15.00 KOPFAN \& KOBE (Iespedeza)

1 Lo. to 10 Lbs. - Ib.-

10 "

$50 "$

$-11-$

GRASS STED

$\mathrm{Bu}$.

CHIET Timothy, - - - - - -4.75

PADUKE " - - - - -4.60

CIIEF Ty. Blue Grass, -
EFDUKE "

CHIEF Crchard " -

PADURE " $"$ " -2.50

CHIEF Red TOP, 100\# - - 25.00

IADUKE " " I00\# - - 24.00

mall Lots Red Top If Ib.Higher.

3IRIUDDA GRASS, - Ib.- - - .50

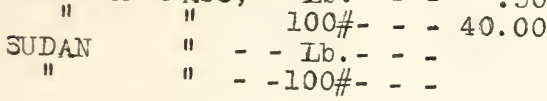

\section{SEED OATS}

Re-cleaned \& Tested

Northern White, - - -
Black Mixed, - - -

Burt, - - - - - - -

Bu.

RAE, DWarf Essex,

100 Lots, Fer Ib. - - .09

50 \# " " "

Small iots " "

\section{SEED SCHERS}

Each

Cahoon, - - . - . - 3.00

Cyclone, - - - - - 2.00

$\mathrm{T}$ in Horn, - . . . . 1.00
SEAD CORN

Faducah Market, - _ .

Silver Mine, - - - . - - 2.50

St. Charles, - - - - - -2.50

Hickory King, - - - - - 2.50

Reid's Yellow Dent, - - - - 2.50

Ieaming Yellow, - - - - -2.50

SEED POTATOES

fied River Trimphs, - - - - I.25

" " $"$ Cobblers, - - - 1.25

Certified Cobolers, - - - - -7.60

Eating rotatoes, - - - -

SCRGHUM SEED-For Forded AnZ. . Fu.

Crange, - - - - - . - -

Amber, - - - . . . - -

REd TOP, - - . - . - -

For iyrup, Gal.

Bu.

G oney Dew-

CNION SETS Ga.l. Bu.

Red or Yellow, - $-.40_{-}--2.25$

SOI BRANS

Namoth Yellows, Ru.

ilimoth Brcins, - $-{ }_{-}-2.25$

IIanchu (Early Yellors) - -

Plack Sabel, - _ _ _ - 2.50

Virginia, - - - - - - - 2.50

Iaredo, - - - - - - -3.50

COT PEAS (Pe-cleaneä)

Mixcd, - _ - _ Bu.

Whippoorwills, _ _ - $\ldots-2.00$

New Eras, - - - $-\ldots$

FERTIIIZHR I25\# SK.

Ton.

Analy is , 4-16-4 - -

Fotato \& Fobacco Gr.

Swifts 2-12-2- - - -

Hoid Frosphate $16 \%$ -

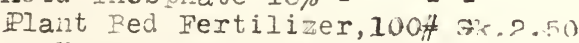
IATF TCINS AT TON TIICES.

ITME, Fer Parrel, - - - - 2.00

$"$ Hydrated, 50 H Fass, - - .50

"Portland "Cenent, Ier " Bas, - - .

FROST IPROOF CARBAGE FIATTS, YEITCVI BERUITA OIION WIANTS, ( $\triangle \mathrm{SK}$ IOR IRICES) 

P. 0 .

\section{ORDER TO YOPP SEED COMPANY}

Incorporated

PADUCAH, KY.

\section{AMOUNT ENCLOSED}

Check

$\$$

M. O. - - \$

Yopp Seed Company, Incorporated, gives no warranty express or or plants it sells, and it will not be in any way responsible for the crop.
Ship to

At

\section{By}

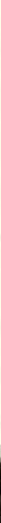





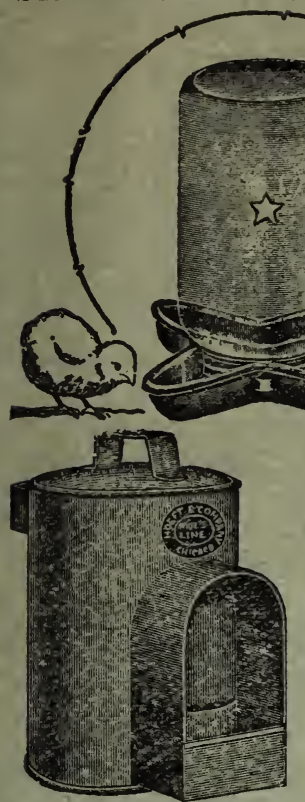

Wall Fountain

No. 98,1 gal. $\$ 1.00$

No. 99, 2 gal.

MOE'S

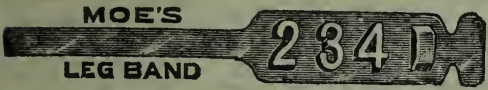

FITS ANY

MASON JAR

Jars Not

Included

EACH 10c

\section{Wall Fountain}

26-A, 1 gal. $\$ .65$ No. 74,5 gal. 1.75

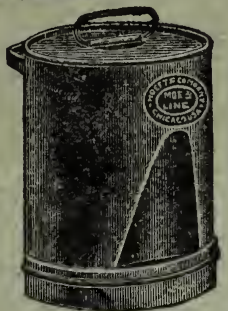

Postage extra on Feeders Fountains.

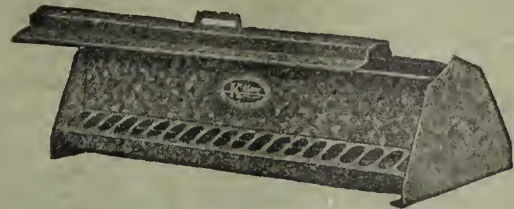

A large capacity feeder meeting with universal success for baby chicks and growing stock.

Hopper is built narrow at top and wide at bottom. assuring an even flow of feed at all times. No bridging or clogging of feed.

Special hinged grill over feeding trough allows ease in cleaning and can be removed when birds have grown too large to eat through the openings. Turned flange on top of feeding trough prevents wasting of feed when grill is removed.

No. 40-Length 24 in., capacity 14 qts., each $\$ 1.00$

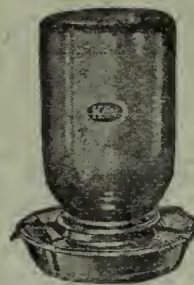

and

\section{Glass Buttermilk Fountain}

Formed wire clip snaps over outer edge of glass pan holding fruit jar firmly in position.

Clip is formed so that standard fruit jar fits. Ideal for feeding clabber, or medicated water.

No. 10-Glass Buttermilk Fountain, jars not included, each15c.

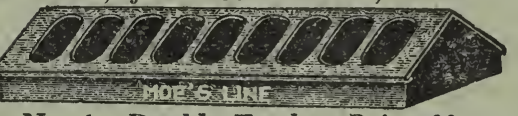

No. 1-Double Feeder, Price 60c

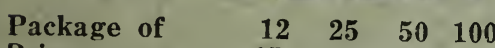

Price

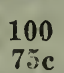

\section{Moe's Regal}

\section{Carrier}

15 egg size, ea. 20c

30 egg size, ea. 40c

$50 \mathrm{egg}$ size, ea. $70 \mathrm{c}$

100 egg size, ea. $\$ 1.25$

CELLULOID LEG BANDS

Baby Chick size_r.r. Doz. 100

Leghorn size

Rock and Red size

TOE PUNCHES

For marking baby chicks, postage paid $25 \mathrm{c}$ each.

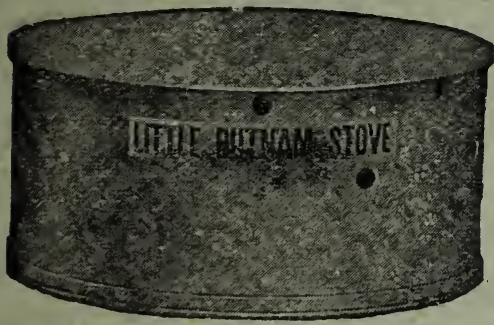

Putman Stoves, $\$ 1.95$ each, postpaid

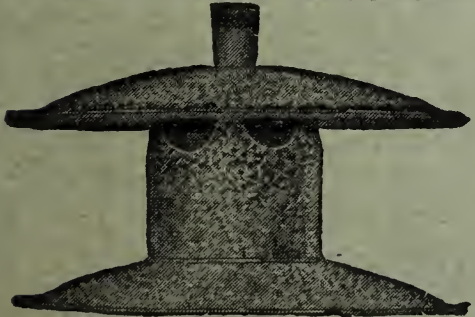

Putman Brooder Heater, $\$ 4.75$ po tpaid

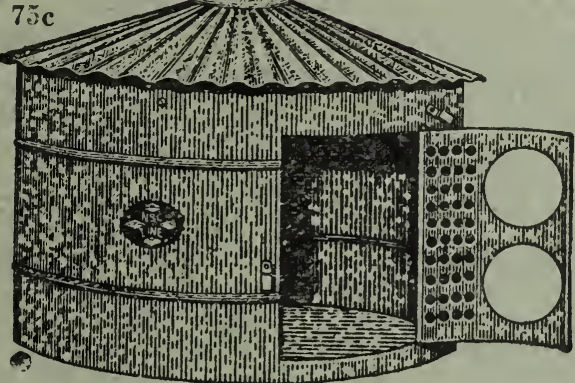

Galvanized Chick Hover

Round and pevents crowding in corners. Rat proof and well ventilated. Easily taken apart and cleaned. Shipping weight 15 lbs. Each $\$ 1.50$. Express or freight charges extra.

Conkey's Poultry Remedies.

Hess' Pan-a-min.

LeGear's Poultry Remedies.

Don Sung Laying Tablets.

B. A. Thomas' Poultry Tonic.

Lee's Egg Maker.

Lee's Lice Killer.

Lee's Louse Powder.

Sodium Floride, lb. 25c.

Conkey's Buttermilk Starter

Conkey's Growing Mash.

Corno Chick Starter.

Corno Growing Mash.

Corno Chick Grains.

Corno Lay:ng Mash.

Full-O-Pep Starter.
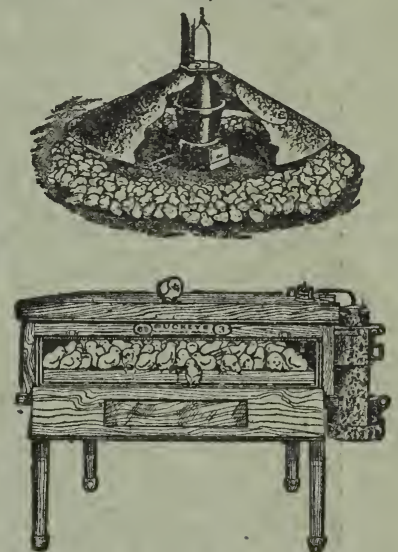

Buckeye Incubators and Brooders, International Sanitary Hovers.

Write for Catalogs

Full-O-Pep Chick Grains.

Full-O-Pep Growing Grains.

Full-O-Pep Laying Mash.

Full-O-Pep Growing Mash.

Yopp's Laying Mash.

Yopp's Scratch or Hen Feed.

Yopp's Chick Feed.

Pigeon Feed.

Charcoal.

Linseed Meal.

Crushed Oyster Shell.

Pearl Grit.

Granulated Bone.

Ground Oats.

Pure Dried Buttermilk

We have a full line of Poultry Supplies. If interested in anything not listed, write us. 


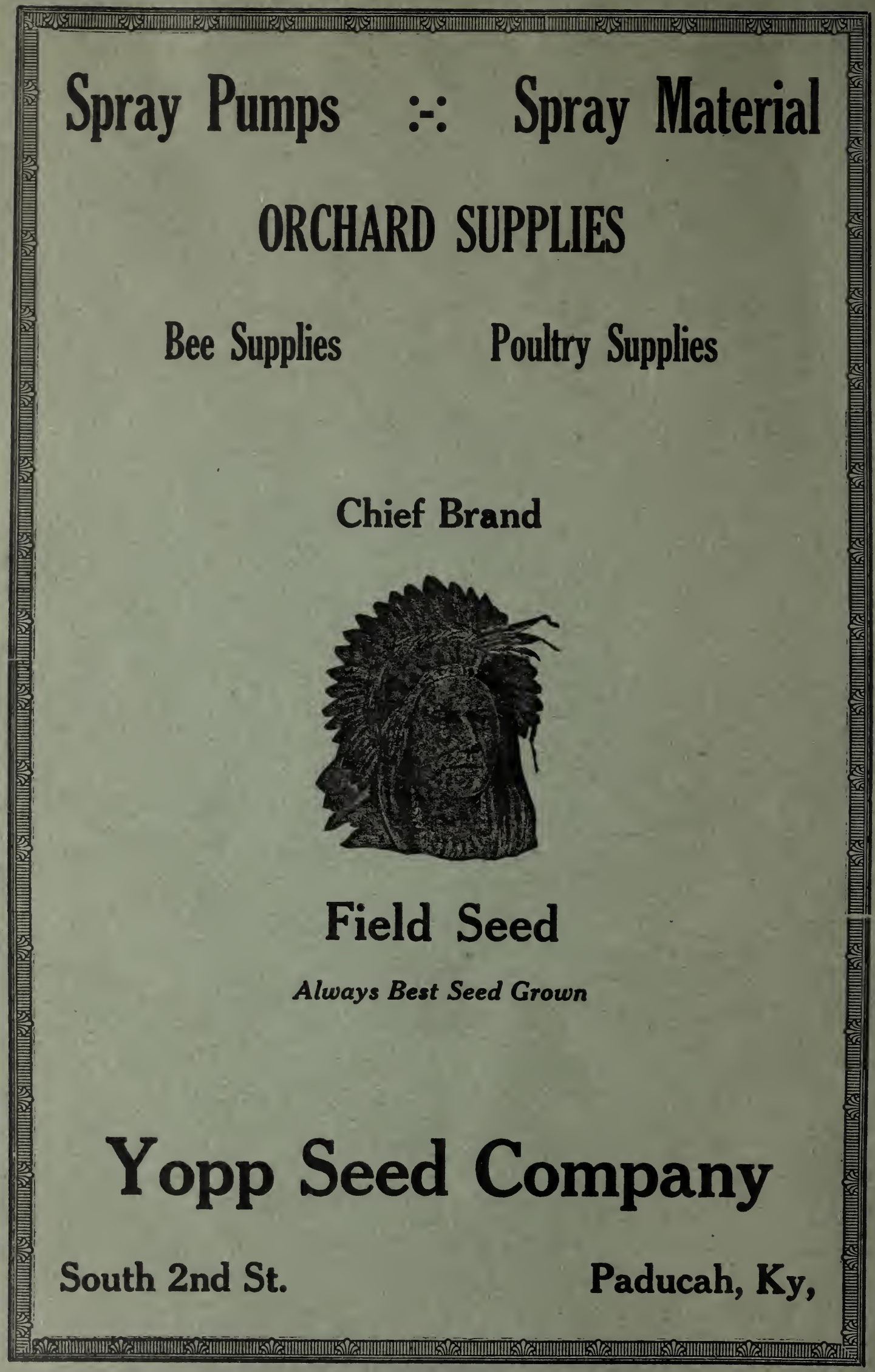

